UNIVERSIDADE DE SÃO PAULO

PROGRAMA DE PÓS-GRADUAÇÃO EM CIÊNCIA AMBIENTAL

\title{
POLÍTICAS PÚBLICAS DE IMPLEMENTAÇÃO DA CONVENÇÃO \\ DA DIVERSIDADE BIOLÓGICA NO BRASIL: O Caso do Baixo Juruá
}

Dissertação apresentada ao Programa de Pós-Graduação em Ciência Ambiental da Universidade de São Paulo como exigência parcial para obtenção do título de Mestre, pelo curso de Pós Graduação em Ciência Ambiental.

Orientador: Prof. Dr. Wagner Costa Ribeiro

São Paulo 
Ficha catalográfica preparada pelo Serviço de Biblioteca da Unidade e colocada no verso da página de rosto. É opcional. 
Data da Defesa:

\section{Banca Examinadora}

Prof. Dr.

Julgamento: Assinatura:

Prof. Dr.

Julgamento: Assinatura:

Prof. Dr.

Julgamento: Assinatura: 
A meus pais, que, desde muito cedo, ensinaram-me o verdadeiro valor dos estudos. 


\section{AGRADECIMENTOS}

Em primeiro lugar, obrigada a meu orientador por ter acreditado em mim e ter-me aberto as portas da Universidade, após doze anos de minha formatura do curso de Direito. Também obrigada à Professora Cristiane Derani, por sua valiosa contribuição nos Comitês de Orientação, suas críticas e seus gentis elogios.

Sou extremamente grata a todos os meus colegas do IBAMA que, de alguma forma, auxiliaram-me na pesquisa ou simplesmente incentivaram-me com um sorriso ou uma palavra de apoio nos momentos mais difíceis de conclusão do trabalho. Agradeço àqueles que pararam seu trabalho, por minutos que fosse, para contribuírem para a construção do meu. Especialmente obrigada a minhas amigas e colegas Ana Claudia e Veri, pelo incentivo diário e precioso e pela ajuda na Procuradoria, sem o qual minha pesquisa estaria comprometida. E obrigada, Walter, por ter me apresentado à Reserva Extrativista do Baixo Juruá e me auxiliado com tão vasto e valioso material.

Não há como deixar de agradecer a minha família, toda ela, pelo entendimento de minhas ausências, pelo socorro para que meus filhos não se sentissem abandonados pela mãe e pelo apoio constante para que meu sonho pudesse se tornar realidade. E, especialmente, meu agradecimento ao meu companheiro e marido, pela paciência e dedicação nestes três anos do meu mestrado.

E, por fim, obrigada aos moradores do Baixo Juruá, a aqueles que tive o imenso prazer em conhecer e a todos aqueles que conservam suas riquezas. 


\section{SUMÁRIO}

\section{RESUMO}

ABSTRACT

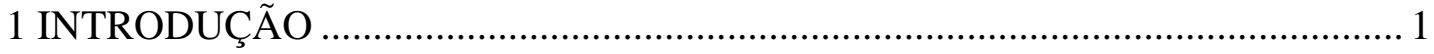

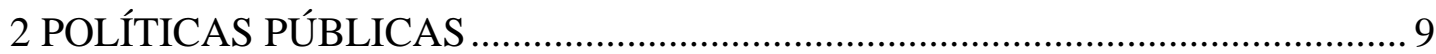

2.1 Integrantes e finalidades das políticas públicas .................................................. 12

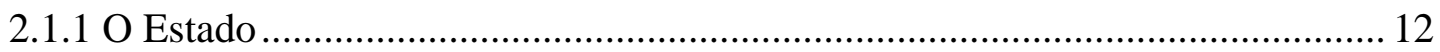

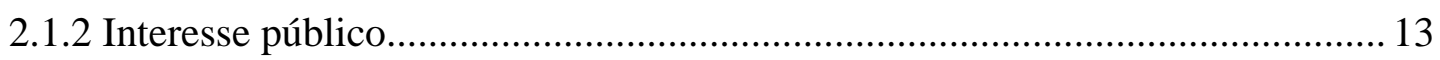

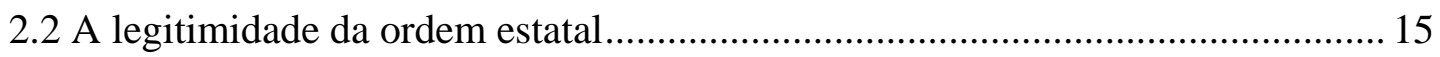

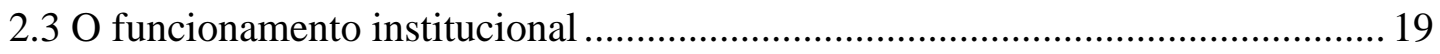

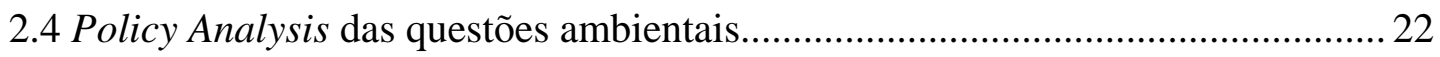

2.4.1 As fases de elaboração de uma política pública.............................................. 25

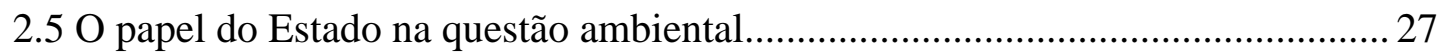

2.6 Algumas políticas ambientais brasileiras ............................................................ 30

3 A CONVENÇÃO DA DIVERSIDADE BIOLÓGICA - A tutela jurídica da

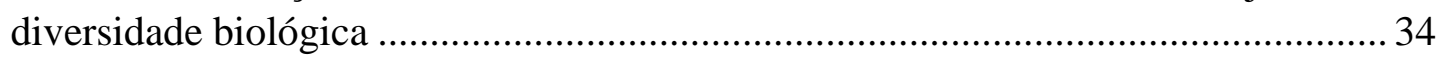

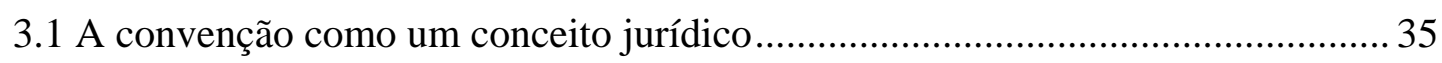

3.1.1 Do procedimento para adoção de um tratado................................................ 38

3.2 A biodiversidade como objeto de tutela jurídica............................................... 40

3.2.1 Principais causas de extinção da biodiversidade............................................. 43

3.2.1.1 Substituição da biodiversidade por monoculturas ......................................... 44

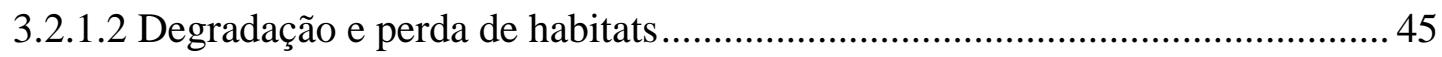

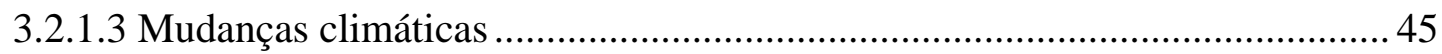

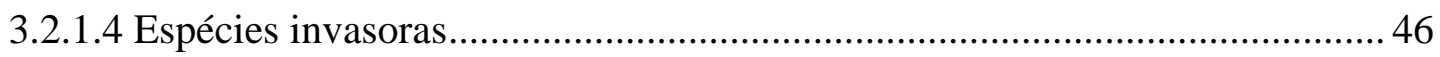

3.3 Convenção da Diversidade Biológica ........................................................... 48 
3.4 O funcionamento da Convenção da Diversidade Biológica ............................... 54

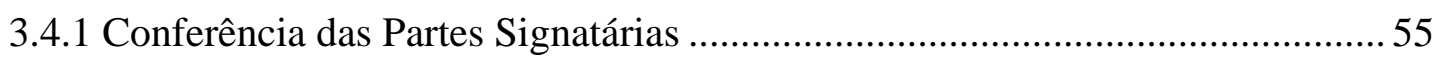

3.4.2 Corpo Subsidiário de Assistência Científica, Técnica e Tecnológica................ 56

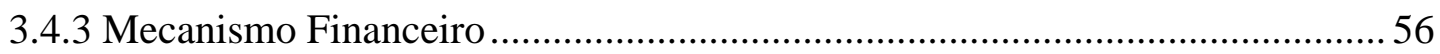

3.5 Problemas e Vicissitudes da Convenção da Diversidade Biológica ..................... 57

3.6 Artigo $8^{\circ}$ - A importância das áreas protegidas segundo a CDB ......................... 63

3.6.1 Grupo de Trabalho da CDB sobre Áreas Protegidas ........................................6 66

4 A IMPLEMENTAÇÃO DA CDB NO BRASIL ................................................. 72

4.1 Ministério do Meio Ambiente e a Conservação da Diversidade Biológica ......... 74

4.1.1 A Secretaria de Biodiversidade e Florestas.................................................... 76

4.2 Programas e Políticas Nacionais referentes à Conservação da Diversidade

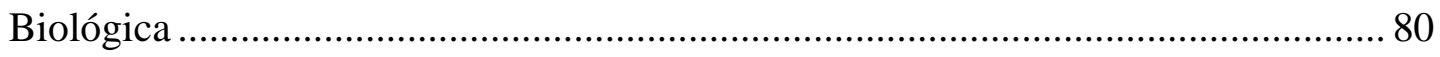

4.2.1 Programa Nacional de Conservação da Biodiversidade .................................... 80

4.2.1.1 Comissão Nacional da Biodiversidade ........................................................ 83

4.2.2 Projeto de Conservação e Utilização Sustentável da Diversidade Biológica

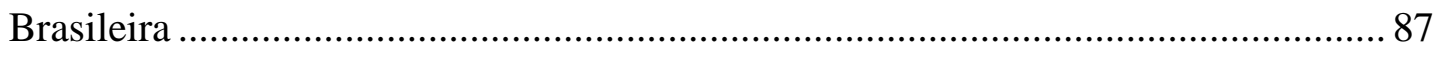

4.2.3 Política Nacional de Conservação da Diversidade Biológica ........................... 93

4.3 Relatórios Nacionais para a Convenção da Diversidade Biológica no Brasil ..... 98

4.4 Da implementação do artigo 8 , letras “a” e “b”, da CDB................................. 104

4.4.1 Programa Áreas Protegidas da Amazônia......................................................... 104

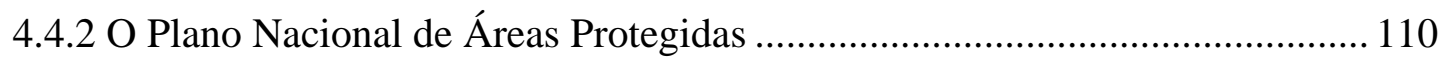

5 A RESERVA EXTRATIVISTA BAIXO JURUÁ ............................................ 116

5.1 As reservas extrativistas e o Sistema Nacional de Unidades de Conservação... 117

5.1.1 Breve histórico do Sistema Nacional de Unidades de Conservação................ 117

5.1.1.1 Indicadores do Sistema Nacional de Unidades de Conservação................... 120 
5.1.2. As Reservas Extrativistas e sua inserção no Sistema Nacional de Unidades de Conservação 126

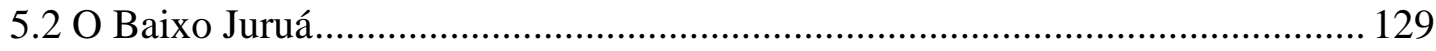

5.2.1 Apresentação da RESEX........................................................................... 129

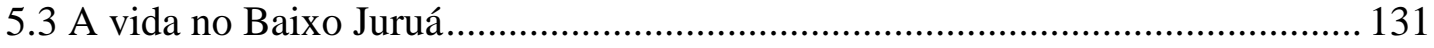

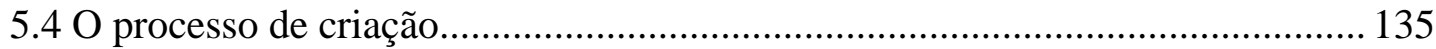

5.4.1 A implantação da Reserva Extrativista a partir de 2001 ................................. 144

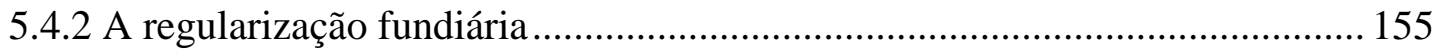

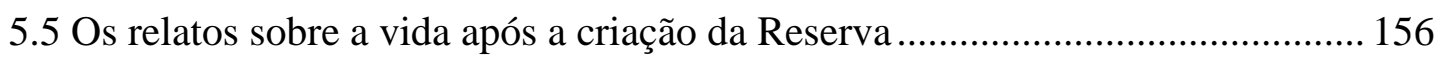

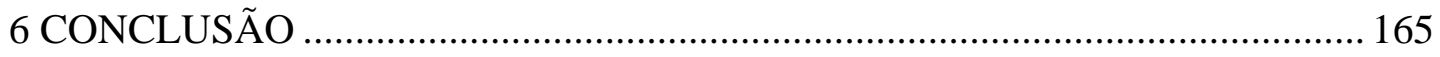

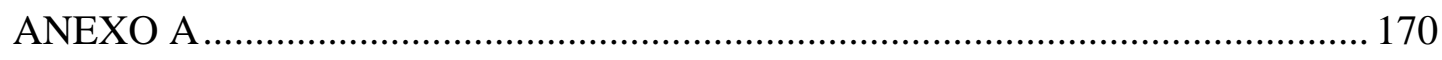

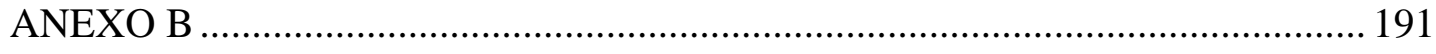

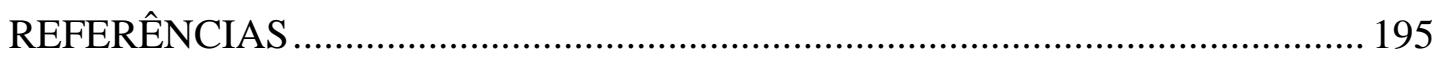




\section{LISTA DE ILUSTRAÇÕES}

Figura 1 - Reserva Extrativista do Baixo Juruá........................................................4

Figura 2 - Mapa de Áreas Prioritárias para a Conservação da Biodiversidade no Brasil. .92

Figura 3 - Unidades de Conservação Apoiadas pelo Programa Áreas Protegidas da Amazônia . .107

Figura 4 - Porto de Juruá. 129

Figura 5 - Comunidade de Cumaru. .131

Figura 6 - Produção de Farinha. 133

Figura 7 - Sede IBAMA/ASTRUJ construída em Juruá 149

Figura 8 - Paraná do Breu. .153

Figura 9 - Macaco da Noite. .159

Figura 10 - Comunidade Antonina .163

\section{LISTA DE TABELAS}

Tabela 1 - Unidades de Conservação federais do Brasil administradas pelo IBAMA. .122 


\section{LISTA DE ABREVIATURAS E SIGLAS}

ABC - Academia Brasileira de Ciências

ABEMA - Associação Brasileira das Entidades Estaduais do Meio Ambiente

ARPA - Programa Áreas Protegidas da Amazônia

ASTRUJ - Associação dos Trabalhadores Rurais de Juruá

BIRD - Banco Internacional para a Reconstrução e Desenvolvimento

CDB - Convenção da Diversidade Biológica

CF/88 - Carta Constitucional Federal de 1988

CNA - Confederação Nacional da Agricultura

CNI - Confederação Nacional da Indústria

CNPq - Conselho Nacional de Desenvolvimento Científico e Tecnológico

CNPT - Centro Nacional para o Desenvolvimento Sustentado de Populações

Tradicionais

CNUMAD - Conferência das Nações Unidas para o Meio Ambiente e

Desenvolvimento

COIAB - Coordenação das Organizações Indígenas da Amazônia

CONABIO - Comissão Nacional da Biodiversidade

CONAMA - Conselho Nacional do Meio Ambiente

CONTAG - Confederação Nacional de Trabalhadores na Agricultura

COP - Conferência das Partes Signatárias da Convenção

CP - Comitê do Programa

DcBio - Diretoria do Programa Nacional de Conservação da Diversidade Biológica 
FAO - Organização das Nações Unidas para a Agricultura e a Alimentação

FUNAI - Fundação Nacional do Índio

FUNBIO - Fundo Brasileiro para a Biodiversidade

GEF - Fundo Global para o Meio Ambiente

GT - Grupo de Trabalho

IBAMA - Instituto Brasileiro do Meio Ambiente e dos Recursos Naturais

Renováveis

IDAM - Instituto de Desenvolvimento Agropecuário do Estado do Amazonas

INCRA - Instituto Nacional de Colonização e Reforma Agrária

INPA - Instituto Nacional de Pesquisas da Amazônia

IUCN - International Union for the Conservation of Nature

LMMC - Like-minded Megadiverse Countries

MCF - Fundo de Cooperação para os países Megadiversos

MCT - Ministério de Ciência e Tecnologia

MMA - Ministério do Meio Ambiente

MONAPE - Movimento Nacional dos Pescadores

OEMA - Organização Estadual de Meio Ambiente

OGM - Organismo Geneticamente Modificado

ONG - Organização Não Governamental

ONU - Organização das Nações Unidas

PNAP - Plano Estratégico Nacional das Áreas Protegidas

PNB - Política Nacional de Biodiversidade 
PNUMA - Programa das Nações Unidas para o Meio Ambiente

PPA - Plano Plurianual

PPG7 - Programa Piloto para a Proteção das Florestas Tropicais do Brasil

PROBIO - Projeto de Conservação e Utilização Sustentável da Diversidade

Biológica Brasileira

PRONABIO - Programa Nacional de Conservação da Biodiversidade

RESEX - Reserva Extrativista

RPPN - Reserva Particular do Patrimônio Natural

SBPC - Sociedade Brasileira para o Progresso da Ciência

SBSTTA - Corpo Subsidiário de Assistência Científica, Técnica e Tecnológica

SEPPIR - Secretaria Especial de Políticas de Promoção da Igualdade Racial

SIVAM - Sistema de Vigilância da Amazônia

SNUC - Sistema Nacional de Unidades de conservação

SUDEPE - Superintendência para o Desenvolvimento da Pesca

UC - Unidade de Conservação

UNDP - Programa de Desenvolvimento das Nações Unidas

UNESCO - Organização das Nações Unidas para a Educação, a Ciência e a Cultura USP - Universidade de São Paulo 


\section{RESUMO}

LERNER, L.C. Políticas Públicas de Implementação da Convenção da Diversidade Biológica no Brasil: O Caso do Baixo Juruá. 2008. 215 p. Dissertação Mestrado - Programa de Pós-Graduação em Ciência Ambiental, Universidade de São Paulo, São Paulo.

A biodiversidade constitui o pilar de sustentação da civilização humana. No entanto, sua manutenção é constantemente ameaçada pelo próprio homem, em face do modo de produção no qual as economias mundiais se baseiam. Conseqüentemente, tornou-se necessário transformar a biodiversidade em um bem jurídico, a fim de regulamentar seu uso, o que foi feito por meio da Convenção da Diversidade Biológica (CDB). Esta reconhece a soberania dos países signatários sobre a diversidade biológica e cultural presente em seus territórios e a importância da conservação dos recursos naturais e genéticos, por meio da criação e implementação de um sistema de unidades de conservação, proteção dos conhecimentos e práticas tradicionais das comunidades locais, dentre outras formas. Estabelece as diretrizes para tal, assegurando a repartição justa e equitativa dos benefícios gerados pelo uso destes recursos.

Ao apresentar as principais políticas públicas implementadas pelo Brasil referentes à conservação da diversidade biológica e tomando por base, especificamente, a criação e implementação de uma área protegida dentro do Sistema Nacional de Unidades de Conservação, este trabalho discute se a criação de reservas extrativistas representa uma alternativa viável à conservação da diversidade biológica e, conseqüentemente, à conservação do estilo de vida das comunidades tradicionais no Brasil. Partindo-se, então, do texto da CDB, discute também se é uma alternativa viável para que o Brasil cumpra seus compromissos junto à CDB.

A análise da criação e implementação da Reserva Extrativista do Baixo Juruá, como estudo de caso, comprova que a criação desta categoria de unidade de conservação apresenta-se como uma alternativa bastante válida para a conservação da diversidade biológica e do modo de vida dos moradores de comunidades tradicionais, principalmente para a região Amazônica, como no caso apresentado. 


\begin{abstract}
LERNER, L.C. Biologial Diversity Convention Public Policies Implamentation in Brasil - Baixo Juruá, a case study. 2008. 215 p. Dissertação Mestrado - Programa de Pós-Graduação em Ciência Ambiental, Universidade de São Paulo, São Paulo.
\end{abstract}

Biodiversity is the mainstream of human civilization. However, its conservation is constantly threatened by mankind and their world production-based economy. It has therefore become necessary to transform biodiversity into an international law wellbeing to regulate its use. This has been achieved by the Biological Diversity Convention (BDC).

The BDC recognizes allied countries' independent right over their own biological and cultural diversity. It also conceives the importance of natural and genetic resources conservation by means of implementing a system of Conservational Units, as well as by the protection of traditional knowledge and practices of local communities among others. The Convention establishes guidelines to achieve these goals, always assuring a fair and equal share of all the benefits obtained from the use of the resources.

This paper presents the main public policies implemented in Brazil for the conservation of biodiversity, more specifically the creation and implementation of a protected area as part of the Brazilian National Conservation Unit System. It looks into the feasibility and efficacy of creating an Extractivist Conservation Unit System regarding biodiversity and traditional communities' lifestyle protection in Brazil according to the BDC established guidelines and goals.

The Baixo Juruá Extractivist Conservation Unit is particularly analyzed, focusing on its creation and implementation. This analysis concludes that such category of Conservational Unit comprises a feasible strategy for biodiversity and traditional communities’ lifestyle protection, especially concerning the Amazon. 


\section{INTRODUÇÃO}

A diversidade biológica, embora não destituída de beleza, não tem como maior qualidade seus atributos cênicos. Seus benefícios para a humanidade são tão diversos e, hoje ainda, desconhecidos que, sabiamente e globalmente, tratou-se de tentar proteger a sua destruição.

Para tanto, em 1992, durante a Conferência das Nações Unidas para o Meio Ambiente e Desenvolvimento (CNUMAD), no Rio de Janeiro, foi assinada a Convenção da Diversidade Biológica, que tem por objetivo a conservação da diversidade biológica de seus países signatários, a utilização sustentável de seus elementos e a repartição justa e equitativa dos benefícios derivados da utilização dos recursos genéticos.

Como membro signatário da Convenção da Diversidade Biológica (CDB), o Brasil obrigou-se a adotar determinadas medidas que visam à conservação da diversidade biológica de nosso país, considerado um dos países megadiversos do mundo.

Quando decidi retornar à Universidade, após longos anos dedicados exclusivamente à Procuradoria Federal, tinha por objetivo não só retomar os 
caminhos de estudante e pesquisadora, mas também estudar o Estado, meu empregador.

Foi, então, que o Prof. Dr. Wagner Costa Ribeiro sugeriu-me investigar as políticas públicas adotadas pelo Brasil em face da Convenção da Diversidade Biológica: um tema instigante e compatível com sua linha de pesquisa no Programa de Pós-Graduação em Ciência Ambiental (PROCAM).

Como operadora do direito e ciente da vasta legislação ambiental de que dispomos, sabia que qualquer pesquisa científica que envolvesse políticas públicas na área ambiental e, conseqüentemente, legislação ambiental, seria uma árdua tarefa. Isto porque, além do fato de não dispormos de um Direito Ambiental codificado, não dispomos também de um Direito Administrativo codificado, o que dificulta e muito a tarefa daqueles que, de alguma forma, interagem com a área ambiental.

Mas não havia como me furtar desta empreitada: adentrar no instigante mundo da pesquisa era mais que um desafio, era a realização de um sonho.

Parti, primeiramente, de um objetivo por demais extenso, que seria tentar responder a seguinte indagação: o que o governo fez após 1992 para conservar a diversidade biológica do Brasil? Isso foi suficiente para cumprir suas obrigações junto à CDB?

Para responder a estas perguntas procurei, primeiramente, sintetizar os passos dados pela Secretaria da Diversidade Biológica, braço do Ministério do Meio Ambiente, a partir de 1993, ano de ratificação da Convenção pelo Brasil. Dessa forma, poderia criar um quadro sintético das políticas públicas adotadas pelo Brasil, que tivessem por objeto a conservação da diversidade biológica. 
Porém, ao iniciar os trabalhos, percebi que seria impossível concluir esta tarefa em três anos. Neste momento, eu tinha por problema da pesquisa responder à seguinte questão: o Brasil tem cumprido com suas obrigações face à Convenção da Diversidade Biológica?

Decidi, então, junto a meu orientador, que a análise de um caso concreto auxiliaria a restringir o âmbito de minhas pesquisas, para concentrá-las em algum aspecto dentro da conservação da diversidade biológica.

A partir deste ponto consegui, de maneira mais clara, definir o real objetivo do meu estudo. Tentar responder à seguinte indagação: a criação e a conseqüente implantação das reservas extrativistas é uma alternativa viável à conservação da diversidade biológica e, conseqüentemente, à conservação do estilo de vida das comunidades tradicionais no Brasil? E, neste sentido, é uma alternativa viável para que o Brasil cumpra suas obrigações junto à CDB?

Ciente da existência do Sistema Nacional de Unidades de Conservação, decidi estudar uma Reserva Extrativista (RESEX) do Baixo Juruá (Figura 1), por ser um tipo de Unidade de Conservação recém inserido ao sistema criado no ano de 2000. Assim, pude concentrar minha pesquisa nas políticas públicas brasileiras concernentes à conservação da diversidade biológica e que se referissem a áreas protegidas. 
Figura 1 - Reserva Extrativista do Baixo Juruá

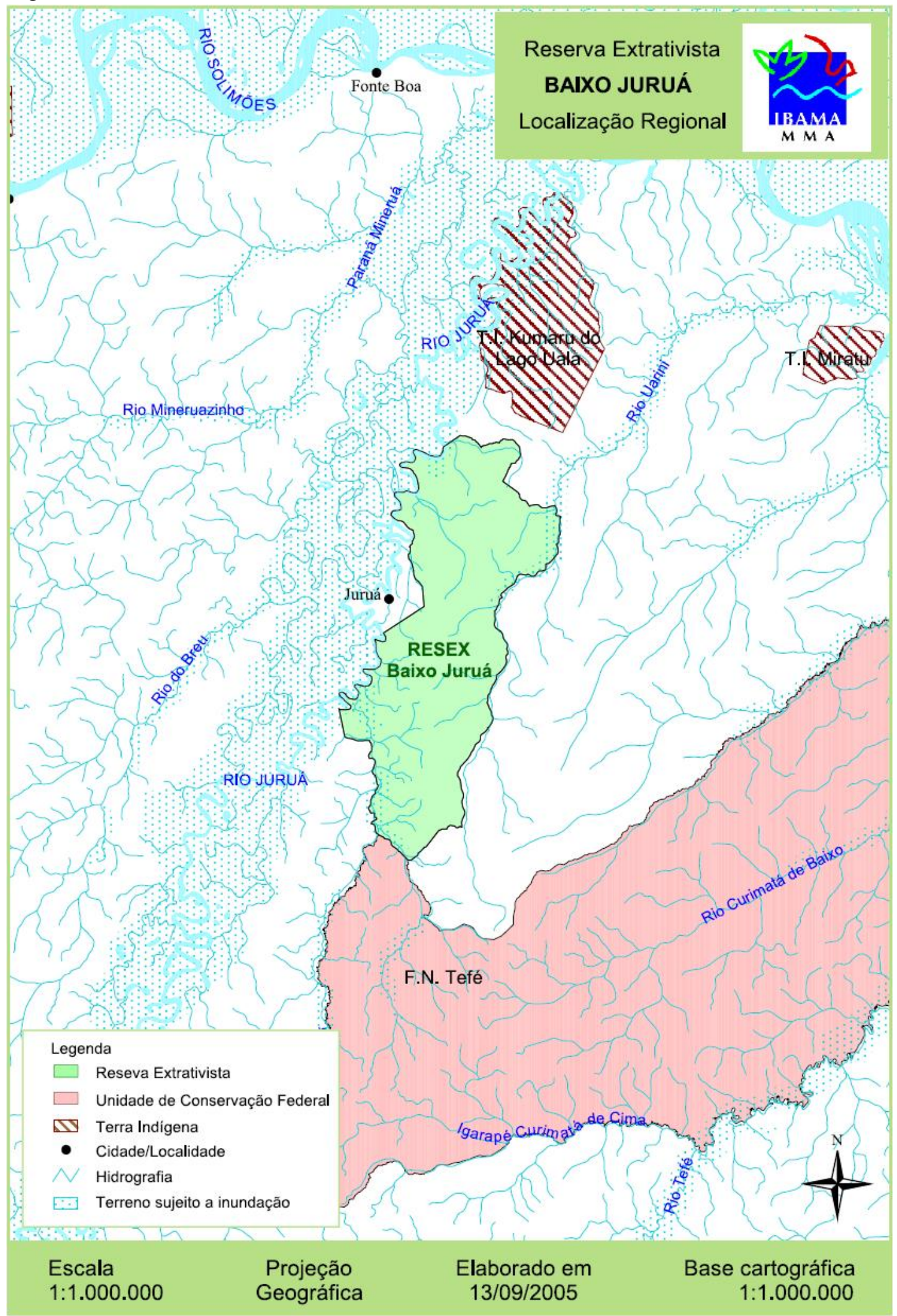

Fonte: IBAMA, 2005, www.ibama.gov.br/siucweb/unidades/tst.php?cod_uc=resex/mapasucs/1032 acesso 10 de janeiro de 2008 . 
Assim, esta pesquisa foi realizada a partir de fontes secundárias - como documentos, processos administrativos e planos nacionais - mas, também, por meio de fontes primárias - entrevistas realizadas por mim com atores destacados no processo de criação da Reserva Extrativista, localizada na Amazônia Legal. Sintetizando, a metodologia aplicada baseou-se em revisão bibliográfica e documental, análise desta documentação e entrevista aberta, semi-estruturada, por telefone, com atores destacados da RESEX (Anexo A).

A base teórica foi dada pela bibliografia pesquisada e fartamente fornecida pelas disciplinas cursadas em diversas unidades da Universidade de São Paulo. Com isto, procurei ter contato com o maior número possível de livros, artigos e outros trabalhos nacionais e estrangeiros, nas diversas áreas estudadas, para consolidar um mínimo de conhecimento multidisciplinar e interdisciplinar que a ciência ambiental requer.

Como eu havia decidido estudar as políticas públicas do Brasil concernentes a um determinado assunto, durante um determinado período, a análise documental foi imprescindível. Para tanto, relatórios, projetos, planos, estratégias e todos os documentos oficiais disponibilizados na Internet foram selecionados e analisados, além de leis, decretos, instruções normativas, portarias e a própria Constituição Federal.

Mas eu não poderia partir apenas de questões tão práticas e soltas. Era preciso criar um arcabouço teórico que desse sustentação a esta grande radiografia dos meandros do governo que eu buscava tirar. 
Para tanto, retornei às raízes de todo estudante da área das Ciências Humanas para buscar em grandes mestres como Locke, Hobbes, Marx, o entendimento de Estado e sua legitimidade para, então, definir políticas públicas. Com isto eu poderia introduzir o leitor em uma abordagem das instituições públicas e nas análises das questões ambientais: os conflitos, os atores e as instituições que intermedeiam soluções. Este é o conteúdo do Capítulo 2.

Uma vez que este trabalho tem por objeto analisar as políticas públicas de implementação da Convenção da Diversidade Biológica no Brasil, foi imprescindível apresentar ao leitor o objeto Convenção da Diversidade Biológica. Para tanto, o Capítulo 3 traz uma apresentação do conceito jurídico de convenção e o procedimento para adoção de uma convenção ou tratado. Ao explicitar as principais causas de extinção da diversidade biológica, explica porque esta se tornou objeto de tutela jurídica. Traz um breve histórico da assinatura da Convenção para, então, explicar seu funcionamento. Ao final, especifica um pouco a análise ao apresentar o trabalho do Grupo de Trabalho de Áreas Protegidas da CDB, um grupo especialmente criado, cujo trabalho surtiu efeitos diretos no Brasil que também foram analisados. Esta especificação explica-se pelo fato acima exposto, de que ao final, será exposto o caso de uma reserva extrativista em especial, que se trata de uma área protegida no Brasil.

O Capítulo 4 apresenta a implementação da CDB no Brasil. Primeiramente, introduz o grande ator, o principal gestor da questão ambiental no Brasil, o Ministério do Meio Ambiente, com sua subdivisão, a Secretaria da Biodiversidade e Florestas. Em seguida, sintetiza os quatro principais programas e projetos de conservação da diversidade biológica no Brasil que se referem, de alguma forma, às 
áreas protegidas: Programa Nacional da Diversidade Biológica e a Comissão Nacional de Diversidade Biológica, Projeto de Conservação e Utilização da Sustentável da Diversidade Biológica Brasileira e Política Nacional de Diversidade Biológica. Depois desta apresentação, trazemos ao leitor a análise dos Relatórios Nacionais para a Conservação da Biodiversidade - documentos oficiais do Brasil entregues à CDB. Ao final do capítulo, a análise especifica-se um pouco mais, para a implementação das letras “a” e "b” do artigo 8, da CDB, que tratam das áreas protegidas. Neste momento traz-se ao leitor o Programa Áreas Protegidas da Amazônia (ARPA), organização estranha ao Estado, anteriormente apresentado, mas que se revela elemento chave na gestão das áreas protegidas na região da Amazônia brasileira. A legitimidade da atuação desta entidade será questionada oportunamente.

E, finalmente, apresenta-se a Reserva Extrativista do Baixo Juruá. O processo de estudo e conhecimento da reserva desenvolveu-se de forma gradual. Primeiro a localização do Processo IBAMA n 02005.001201/97-33, que tem por objeto a criação da reserva e está totalmente descrito no Capitulo IV. Depois, por ter sido mencionada neste primeiro processo, a tentativa de localização do Estudo SócioEconômico da Reserva Extrativista do Baixo Juruá, documento em que se baseia o processo de criação. Foram longos meses até sua localização. Seus principais dados também se encontram neste capítulo. Seguem as entrevistas, primeiro com analistas ambientais, um ex-chefe da Unidade de Conservação e o outro, atual chefe. Após, a entrevista com os moradores, pessoas extremamente educadas prontas a prestarem auxílio, cedendo informações a uma pesquisadora, marcando horário para cederem as entrevistas por telefone na sede da Associação dos Trabalhadores Rurais de Juruá. 
As principais informações estão resumidas neste Capítulo e as entrevistas estão na íntegra nos anexos deste trabalho.

Ao final, foi incorporado ao trabalho, como Anexo B, um documento enviado por correio eletrônico pelos Srs. Luiz Rocha Maciel e João da Silva Ferreira, entrevistados, para que me auxiliasse em meus estudos, segundo palavras dele. Trata-se de um histórico da formação da Associação dos Trabalhadores Rurais de Juruá que, infelizmente, não possui nome do autor, nem data de elaboração. Não poderia deixar de mencioná-lo e anexá-lo a este trabalho, também pela presteza e educação daquelas pessoas que, espontaneamente, telefonaram para minha casa, para avisar sobre a localização do documento e o envio. 


\section{POLÍTICAS PÚBLICAS}

Apresentar um trabalho concernente às políticas públicas implementadas pelo Brasil após a assinatura da Convenção da Diversidade Biológica exige uma reflexão teórica e conceitual. Por isso, o primeiro capítulo discute os conceitos de Estado, interesse público e legitimidade da ordem estatal sob a ótica de estudiosos da organização social humana. Em seguida, descreve as fases de elaboração de uma política pública e comenta o funcionamento institucional. Traz ainda a visão de investigadores das ciências políticas, por meio da exposição das bases políticas que norteiam o estudo da implementação da CDB no país. Por fim, discorre sobre o papel do Estado na questão ambiental, exemplificada por algumas políticas ambientais brasileiras.

Pensar em políticas públicas significa pensar em instituições de uma sociedade ou, ainda, pressupor a existência de um interesse comum que consolide e justifique a existência dessas instituições. Maximizar o bem-estar social requer a elaboração de planos gestores que visem à mitigação de conflitos e obtenção de ganhos, o que resultará no alcance do interesse comum. Caberá sempre ao Estado empenhar-se para alcançar os fins da sociedade, sejam eles no âmbito da educação, da ordem social ou da conservação do meio ambiente. 
A existência de conflitos sociais e, conseqüentemente, da pressão para solução desses conflitos formará agendas, no âmbito dos Estados. A percepção desses conflitos muda de acordo com os gestores públicos, e isto fixará a agenda de diferentes formas. Fixadas as agendas, estas farão surtir programas de governo que, por fim, tornar-se-ão políticas públicas a partir do momento em que forem institucionalizadas. Entretanto, esta institucionalização pressupõe a existência de financiamento para sua implementação.

O desenrolar deste processo pode se dar dentro de um sistema autoritário ou democrático. No sistema democrático, pode se desenrolar sob um enfoque populista. Um enfoque autoritário pode impor uma visão tecnocrática que ignore demandas sociais.

Analisar as políticas públicas adotadas pelo Brasil para implementação da Convenção da Diversidade Biológica requer, necessariamente, uma análise teórica do processo de elaboração e implementação de políticas públicas.

Por sua vez, tal análise requer uma confrontação com a relação entre o Estado e a sociedade civil. Caso contrário, estar-se-ia admitindo que a formulação de políticas públicas tem por fundamento única e exclusivamente uma determinação jurídica.

Na verdade, além da determinação jurídica, que deve sempre ser respeitada em um Estado democrático de direito, o que se estabelece é uma dinâmica conflitiva que envolve interesses de diferentes classes sociais.

O direito brasileiro e, mais especificamente, o direito constitucional brasileiro, estabelece que a atividade pública deve sempre ter por finalidade a 
consecução do interesse coletivo. Este, por sua vez, deve prevalecer sobre o interesse individual de cada cidadão. Entretanto, se tal imposição fosse algo fácil de atingir, problemas ambientais atuais gravíssimos - que se refletem na poluição de corpos d'água, na destruição de florestas e no aquecimento global - não existiriam.

Também não se pode afirmar que o Estado brasileiro, ao menos no âmbito das questões ambientais, formule políticas públicas para o benefício exclusivo da classe dominante de nosso país. Tal afirmativa estaria por ignorar a força política das diversas organizações não governamentais que atuam em nosso país e de outros segmentos sociais, hoje um pouco mais participativos na atividade estatal.

Não se pode duvidar, também, que a definição das políticas públicas brasileiras estejam condicionadas ao interesse das elites, uma vez que nosso modo de produção capitalista cria verdadeiras amarras econômicas à atividade estatal.

Hoje, pode-se afirmar que decisões quanto à formulação de políticas públicas não se restringem a condicionantes do contexto nacional. Há, na verdade, um contexto constituído da esfera internacional, nacional e também a local.

Este capítulo explicitará as etapas de elaboração e o estabelecimento de políticas públicas e discutirá como estes influem nesta elaboração.

As políticas públicas refletem as respostas do Estado às demandas que surgem do interior da sociedade e, desta forma, são a expressão de sua atuação em determinada área. 


\subsection{Integrantes e finalidades das políticas públicas}

Política, segundo Hely Lopes Meirelles (1990), “é a forma de atuação do homem público quando visa a conduzir a administração a realizar o bem-comum.”. Para este autor, a Política deve reger-se por princípios éticos comuns a todas as necessidades do bem coletivo, guiando-se por motivos de conveniência e oportunidade.

As políticas públicas podem ser entendidas, de maneira muitíssimo simplificada, portanto, como ações do Estado para atender ao interesse público. Por isso, é preciso expor elementos de compreensão sobre o Estado e sobre o interesse público.

\subsubsection{O Estado}

Dalmo de Abreu Dallari assinala, em sua obra “O Futuro do Estado” (1980), a multiplicidade de conceitos de Estado formulados pelos diversos autores que têm se dedicado ao estudo do tema. Para Dallari, após dois mil e quinhentos anos de discussão sobre o assunto, não se pode afirmar que tenhamos chegado a nenhuma espécie de uniformidade.

Alguns conceitos podem ser tão amplos quanto o de Sir Edward Meyer, que atribui ao Estado a condição de princípio organizador de todas as sociedades, como restritivos ao extremo. A par desta dicotomia, partamos para a apresentação de alguns conceitos que se colocam em uma posição intermediária.

Alguns esclarecimentos se fazem necessários antes de iniciarmos tal discussão. Se, em um primeiro momento, houve uma aproximação do conceito de 
Estado ao de “fenômeno político", hoje, podemos afirmar, segundo Duverger, que a sociologia política recoloca o político no social. Desta forma, aproxima-se o objeto de estudo Estado de toda a fenomenologia social.

Hans Kelsen (1951) define o Estado como “um agrupamento de indivíduos, vivendo num território nitidamente delimitado e submetido a um poder juridicamente organizado.” Porém, a reconstrução do Estado como ordenamento jurídico não conseguiu - tampouco deveria - que se omitisse que o Estado era também, através do direito, uma forma de organização social e, portanto, não poderia ser dissociado dela.

Nesta corrente de estudiosos sociológicos do Estado podemos citar Poulantzas (1980), para quem o Estado significava um conjunto de atores sociais que justificam sua permanência no poder. Segundo este autor, o Estado possui um papel de organização: ele representa e organiza a classe ou as classes dominantes. Com a hegemonia e direção do Estado, mantém-se um equilíbrio instável entre os seus componentes.

\subsubsection{Interesse público}

Retornando ao cerne das questões de política públicas, ou seja, àquela idéia de que políticas públicas são ações do Estado para atender ao público, devemos nos ater agora a uma análise, ainda que sucinta, do que se entende por público e como o Estado se organiza a fim de atender àquilo que entende por público.

Como identificar o interesse público e quem deveria fazê-lo são duas questões tradicionais da filosofia política. Apesar de não haver uma definição precisa de 
interesse público, não há como negar que este conceito fundamenta as discussões sobre políticas públicas.

A primeira questão que se coloca é se realmente existe um interesse público.

Pensadores de épocas monarquistas deixaram-nos a idéia de um interesse público distinto daquele dos indivíduos que compõem o grupo social. Surgiu, no século XVII, o pensamento de afirmação do interesse do Estado acima das opiniões da família reinante. O interesse público, portanto, não seria a soma dos interesses de cada indivíduo e, sim, o interesse da coletividade.

Com John Locke, nasceu a idéia do bem comum: ao Estado cabe a persecução do bem comum por meio da regulamentação das condições externas da vida em sociedade. Segundo os pluralistas, não se pode identificar o interesse público: este é a preferência da coalizão de grupos que, num dado momento, consegue impor sua definição do problema e as soluções correspondentes. Por outro lado, para os marxistas, a noção de interesse público existe para esconder os interesses de uma determinada classe social.

Weffort, em Os Clássicos da Política, ao tratar de Marx e da emancipação social e política, ressalta:

"Como Marx o diz de forma lapidar: as idéias da classe dominante 'são idéias de seu domínio’. Longe de afirmar o caráter meramente reflexo das idéias, isso significa que a luta de classes é tanto uma luta no plano material quanto uma luta no plano das idéias. É certo que 'as idéias daqueles que não dispõem dos meios da produção intelectual ficam sujeitas à classe dominante'.” (WEFFORT,2006, p.241) 


\subsection{A legitimidade da ordem estatal}

Existem várias teorias que justificam a existência do Estado e, conseqüentemente, o fundamento do poder político. Trata-se de um questionamento que leva à pergunta: por que existe uma relação entre indivíduos que mandam e outros que obedecem na sociedade? Para facilitar a explanação, podemos dividir as diversas respostas, que foram alcançadas ao longo dos séculos, em alguns grandes grupos.

Primeiramente, podemos citar o grupo das justificações teológico-religiosas, aquelas que afirmavam que o poder de governo era exercido em nome e sob a influência dos deuses, havendo, desta forma, uma justificação natural por parte dos que eram subordinados ao poder. Tais teorias predominaram no mundo inteiro, durante milênios e começaram a ser contestadas apenas a partir do século XVII.

Já as chamadas teorias racionalistas agrupam todas aquelas que justificam o Estado como produto da razão humana, conhecidas como teorias contratualistas ou pactistas. Elas justificam o Estado ou o seu nascimento por um acordo entre os indivíduos que o compõem. São exemplos desta escola grandes estudiosos como Emmanuel Kant (1724-1804) e Thomas Hobbes (1588-1679). Segundo este último escritor, os homens não se agrupam por fazer parte de sua natureza mas, pelo contrário, associam-se face sua necessidade de se armar contra outros homens. Desta forma, o poder atribuído a este Estado deve ser ilimitado, a fim de que a proteção ao indivíduo possa se efetivar.

Hobbes foi um defensor do absolutismo, fundamentando sua teoria na razão e natureza do homem, diferenciando-se, assim daqueles que fundamentavam o 
absolutismo no poder divino. Para ele, os homens, ao realizarem um pacto voluntário constitutivo do estado, delegavam a ele a totalidade dos seus direitos naturais de liberdade e autodeterminação.

Milton Meira Nascimento escreveu sobre este autor, sintetizando:

"Para Thomas Hobbes, os homens não têm outra escolha: ou se organizam em sociedade ou se destroem mutuamente, pois a condição que antecede a formação da sociedade política é aquela da guerra de todos contra todos que caracteriza o estado de natureza, onde o homem vive na solidão e onde impera a lei domais forte. Para sobreviver vale tudo no estado de natureza. Não há leis, não há governo, não há sociedade possível. É para por um fim a esta condição de miséria onde a vida é incerta que os homens se decidem a constituir a sociedade política. Mas o preço que elas têm de pagar por isso é muito alto. Eles trocam a liberdade pela segurança.” (NASCIMENTO, 1987, p.241-242)

Ainda dentro das teorias contratualistas, mas contrapondo-se às idéias absolutistas de Hobbes, podemos citar John Locke (1632-1704), precursor do liberalismo na Inglaterra de então. No ano de 1690, Locke afirmou que o direito à vida, assim como todos os direitos inerentes à personalidade humana são indelegáveis e indisponíveis. Desta maneira, ao firmarem o pacto social, os homens delegavam ao órgão diretivo apenas aqueles direitos necessários à manutenção da paz e da segurança de todos.

Outro nome a ser citado dentro do grupo dos teóricos racionalistas é Jean Jacques Rousseau (1712-1778). Este filósofo entendia o Estado como a soma da vontade manifestada pela maioria dos indivíduos. Assim, o governante exercia um poder legal, decorrente da soberania nacional, e deveria perseguir o bem comum. Caso não o fizesse poderia ser substituído. Na obra "Contrato Social”, percebemos 
que ele não só procura responder à questão do fundamento do poder político, mas também transcendê-la, procurando estabelecer as bases de sua legitimidade.

Para este autor, a obediência às leis não poderia nunca se configurar como obediência a um homem ou a um grupo de homens, mas como obediência a si mesmo. As leis a serem obedecidas deveriam ser o resultado de uma decisão comum, que envolvesse todos os cidadãos, assim denominados exatamente porque faziam parte de uma associação política.

Já no século XX, Norberto Bobbio (1987) aponta que, sem o intuito de esgotar o assunto, podemos apontar seis princípios de legitimidade, que se referem antiteticamente a três grandes princípios unificadores: a Vontade, a Natureza e a História.

No caso dos princípios que se referem a uma vontade superior, aponta para uma concepção descendente do poder, como em uma pirâmide, sendo que a autoridade última seria a vontade de Deus. Contrariamente a este, em uma concepção ascendente do poder a autoridade última seria a vontade do povo - o poder sobe da base ao vértice. É importante ressaltar que, segundo as palavras de Bobbio, estes princípios não são antitéticos, mas sim se reforçam no sentido de que a voz do povo sempre vai representar a voz de Deus.

Por outro lado, no caso dos princípios naturalistas, havia a concepção da natureza como força originária do poder, ou seja, independentemente da vontade humana, há o dever de comandar de uns, que são os fortes, e o dever de obedecer de outros, que são naturalmente fracos. Contrariamente, a natureza pode legitimar o 
poder, na medida em que caberá ao governante tornar possível, mediante o exercício do poder coativo, a observância das leis naturais.

Dentro do âmbito histórico, a teoria tradicionalista do poder entende que soberano legítimo é aquele que exerce o poder desde tempo imemorial. E de forma contrária, os revolucionários entendem a legitimação do poder naquilo que muda em correspondência com o movimento, predeterminado e compreendido no processo histórico.

Hans Kelsen (1951), por sua vez, caracterizou o Estado como fenômeno essencialmente jurídico, eliminando da caracterização deste estudo, tudo o que não fosse puramente jurídico. Para este autor, o elemento que se destaca, portanto, é o da submissão deste agrupamento de indivíduos a uma ordem, ou à autoridade do Estado. Não haveria o Estado se não houvesse as normas que regulam a conduta humana e a submissão a elas.

Tal submissão não se dá, nos dizeres de Kelsen, voluntariamente, mas sim pelo fato de que sobre cada conduta humana recai um conjunto de regras de ordenamento e sanção, formando um sistema ou uma ordem única. A relação Estado-indivíduo difere das relações entre os indivíduos, porque se baseia em uma relação de poder ou dominação que não se confunde, de forma alguma, com as relações de força entre homens. Podemos concluir, portanto, que o Estado só existe enquanto ordem normativa, pois caso não existisse um ordenamento normativo que regula condutas e estabelece regras, não haveria a conformação e submissão dos indivíduos. Esta é a visão positivista de Estado. 
Partindo-se de uma visão positivista ou não, se observa que, há vários séculos, se desenvolve um esforço no sentido de impor limitações jurídicas ao poder político, exercido por meio do Estado (DALLARI, 1980, p.4). A evolução da teoria jurídica do Estado permitiu que atingíssemos um ponto em que não mais se considera regular qualquer ato do Estado à margem do direito ou contrário a este.

Com a fixação de regras e princípios gerais, procura-se restringir e condicionar o uso do poder arbitrário do Estado, necessário em certa medida para a consecução de sua finalidade maior, que é o bem comum do povo.

A Constituição Federal do Brasil, publicada em 1988, após anos de regime ditatorial instalado em nosso país, não fugiu a esta tendência e consagrou no caput do artigo 37, o Princípio da Legalidade segundo o qual, nos dizeres de Hely Lopes Meyrelles:

"A legalidade como princípio de administração (Const. Rep., art.37, caput), significa que o administrador público está, em toda sua atividade funcional, sujeito aos mandamentos da lei, e às exigências do bemcomum, e deles não se pode afastar ou desviar, sob pena de praticar ato inválido e expor-se à responsabilidade disciplinar, civil o caso $e$ criminal, conforme.” (MEIRELLES, 1990, p.78)

\subsection{0 funcionamento institucional}

Analisar as políticas públicas remete, necessariamente, à análise do funcionamento das instituições políticas de determinada sociedade. Isto se explica pelo fato de que a implementação de uma política pública, segundo os ensinamentos de Le Prestre (2000), pressupõe um sistema de medidas jurídicas e políticas que, por sua vez, só podem ser tomadas por meio de instituições políticas. Significa, em 
outras palavras, identificar que atores dispõem de qual poder e de onde emana tal poder para implementar políticas públicas.

Primeiramente, devemos nos ater a uma conceituação do termo instituições políticas. Prittwitz (1994) conceitua instituições políticas como padrões regularizados de interação, praticados pelos atores sociais que os reconhecem como legítimos mesmo que não concordem com eles. Resultam de processos políticos e, desta forma, refletem relações de poder existentes (PRITTWITZ apud FREY, 2000).

Trazendo à baila novamente os ensinamentos de Klaus Frey, há uma tendência atual nas análises políticas de se atribuir maior importância aos conteúdos da política do que às condições institucionais que se apresentam (FREY, 2000). Também, segundo este mesmo autor, não se pode atribuir exclusivamente ao fator instituições frágeis a culpa pelo fracasso de uma política pública.

A análise das políticas públicas deve-se estender para além dos fatores apontados acima, chegando a um ponto mais profundo de questionamento, especificamente no tocante à pergunta: a existência de um sistema institucional estável deve ser considerada um fator positivo para a implementação de políticas públicas?

Se, por um lado, as instituições públicas servem para a satisfação das necessidades humanas e estruturação de interações sociais, por outro, estabelecem situações de poder, eliminando a possibilidade de ações por parte dos cidadãos e, conseqüentemente, cerceiam a liberdade individual. Para O’Donnell (1991) a institucionalização de um governo traz consigo o terror da burocratização e todas suas conseqüências negativas (p.25-40). 
No tocante às instituições políticas brasileiras, podemos afirmar que o poder para governar está estabelecido na Carta Constitucional de 1988 (CF/88). Resultado do trabalho da Assembléia Nacional Constituinte, foi instituída entre os anos de 1986 e 1988, com a missão de restabelecer as prerrogativas democráticas perdidas ao longo dos 20 anos de ditadura vividos pelo Brasil. Neste documento se encontra a enumeração dos atores políticos dotados de capacidade e poder para gerir o Estado brasileiro. Além deles, é preciso lembrar a capacidade de pressão dos movimentos sociais organizados.

Atentando-se, agora, à questão do funcionamento das instituições brasileiras, não há como negar que o tipo de regime presidencialista de governo, adotado pela Constituição Federal de 1988, bem como a forma de Estado federativo e o sistema partidário, influem fortemente no desempenho das instituições como um todo. Isto porque a CF/88 estabelece que o chefe do Executivo, eleito com o voto popular, deverá nomear e dirigir a composição do governo, cabendo a ele, também, poderes legislativos constitucionais. Por outro lado, o federalismo, caracterizado por forte distribuição de receitas fiscais entre União, Estados e Municípios, bem como o sistema partidário brasileiro extremamente fragmentado, contribuem para uma forte concentração do poder decisório nas mãos do Executivo, acarretando em problemas graves de governabilidade.

Desta forma, e face à dispersão de poder estabelecida pelo federalismo consistente e sistema partidário fragmentado, a Presidência exerceu, desde a volta do regime democrático ao país, poderes legislativos, administrativos e distributivos de forma excludente, afastando os demais atores do poder. Tal afirmativa é facilmente 
confirmada através do número altíssimo de Medidas Provisórias editadas pelos Presidentes desde 1988.

A confrontação cotidiana entre os poderes Legislativo e Executivo, que usurpa do Congresso o poder de discutir e votar Projetos de Lei, faz surgir problemas de governabilidade com freqüência, havendo até uma deterioração do sistema de representação.

A fragilidade das instituições políticas no Brasil não tem, nesses fatos apontados acima, suas únicas justificativas. Trata-se de um problema antigo e grave da sociedade brasileira.

Conforme já afirmado, não se pode culpar apenas as instituições de dado grupo social como as únicas responsáveis pelo fracasso de políticas públicas. Mas, o que este trabalho procura demonstrar é a necessidade de busca de alternativas que mudem, minimamente, o foco das análises políticas para a questão da diversidade dos atores envolvidos nas questões ambientais. Trata-se da gestão socioambiental, que será discutida ao final deste capítulo.

\subsection{Policy Analysis das questões ambientais}

Segundo Klaus Frey (2000), as investigações no campo das ciências políticas podem ser divididas em três grandes grupos. O primeiro seria composto por aquelas investigações que têm por objeto o sistema político vigente de determinado Estado. Em um segundo grupo, estariam juntas as investigações que analisam as forças políticas cruciais no processo decisório. E por fim, podemos colocar as investigações que questionam os resultados que um sistema político produz. 
Ainda, segundo este mesmo autor, a abordagem da "policy analysis” analisa a inter-relação entre as instituições políticas, o processo político e os conteúdos da política, tendo por objetivo sempre montar um arcabouço teórico das leis e princípios próprios das políticas específicas.

Há três dimensões do cenário político que devem ser destacadas:

1. Polity - refere-se à ordem do sistema político;

2. Politics - refere-se ao processo político;

3. Policy - refere-se aos conteúdos da política.

Esta diferenciação demonstra grande utilidade para estudos de casos na área das ciências políticas. Entretanto, para determinados casos específicos de políticas públicas setoriais, como é o caso da política ambiental, não se demonstra perfeitamente adequada, uma vez que, a cada momento, novos atores políticos passam a fazer parte do cenário, alterando o modelo sugerido acima.

Cumpre ressaltar que tais dimensões, apesar de terem sido diferenciadas, não se apresentam independentes entre si. Pelo contrário, as estruturas políticas (polity) e os processos de negociação política (politics) influenciarão sempre o resultado final (policy). E ainda, disputas políticas acirradas com enfrentamento ideológico dos atores sociais deixarão marcas nos resultados finais, ou seja, nos programas e projetos desenvolvidos e implementados.

No caso específico das políticas ambientais, o aumento da consciência ambiental trouxe à tona conflitos de interesses sociais e econômicos, cabendo ao Estado agir como mediador e negociador. Pedro Jacobi explica a evolução do 
ambientalismo brasileiro e assinala a respeito das respostas buscadas por este movimento:

"As questões que o ambientalismo coloca estão hoje muito associadas às necessidades de constituição de uma cidadania para os desiguais, à ênfase dos direitos sociais, ao impacto da degradação das condições de vida decorrentes da degradação socioambiental, notadamente nos grandes centros urbanos, e à necessidade de ampliar a assimilação pela sociedade de práticas centradas na sustentabilidade." (JACOBI, 2003, p.541)

O surgimento desses conflitos acarretou o surgimento de novos atores no cenário político ambiental sendo que, com esta reorientação, tornaram-se mais importantes os arranjos institucionais, as atitudes e objetivos dos atores políticos.

Assim, ainda segundo Frey (2000), podemos distinguir três novas categorias dentro da "policy analysis":

1. policy networks- redes de relações sociais regulares e informais;

2. policy arena- espaço de configuração do conflito e da negociação;

3. policy cycle- o ciclo da política.

Alguns autores diferenciam os ciclos da política, de maneira genérica, nas fases de formulação, implementação e controle dos impactos da política. Frey prefere uma distinção detalhada trazendo-nos as seguintes fases: percepção e definição de problemas, “agenda setting”, elaboração de programas e decisão, implementação de políticas e por fim avaliação de políticas e eventual correção.

As novas categorias elencadas dentro da policy analysis (networks, arena e cycle) pressupõem um sistema político-administrativo democrático em sua gênese, pois acarretam uma flexibilização da hierarquia formal tradicional. As antigas 
instituições, burocráticas e extremamente poderosas, abrem espaço para uma maior descentralização, que se demonstra estratégica para a evolução das democracias.

Frey ainda, ao tratar das questões conceituais referentes às políticas públicas, afirma que, no caso das políticas públicas ambientais (consideradas um tipo de política pública setorial) as disputas políticas e as relações de forças de poder influenciarão fortemente os programas e projetos que serão desenvolvidos e implementados. Isto porque, com o aumento da consciência ambiental da população em geral, os conflitos entre interesses econômicos e interesses ecológicos aumentaram fortemente. Desta forma, o resultado de uma política ambiental nos dias atuais, reflete um processo político de forte enfrentamento, intermediado por estruturas institucionais. O autor afirma também que os fatores condicionantes das políticas públicas variam ao longo do tempo (FREY, 2000).

No caso específico das políticas ambientais, se presencia, nos dias atuais, o fortalecimento de regimes colaborativos nas políticas públicas. Mas, para se atingir esta colaboração, é preciso criar mecanismos que preparem a sociedade para um modelo de governança ${ }^{1}$. A participação da sociedade na gestão dos problemas ambientais é condição si ne quanon para se alcançar a eqüidade.

\subsubsection{As fases de elaboração de uma política pública}

Le Prestre (2000) identifica sete fases da política pública, sendo elas:

\footnotetext{
${ }^{1}$ A Comissão sobre Governança Global, 1995, define governança como sendo “a soma total dos vários modos como indivíduos e instituições, públicas e privadas, administram seus negócios comuns. Tratase de um processo contínuo, através do qual, interesses conflitantes ou diversos podem ser acomodados e uma ação cooperativa encetada. Esse processo inclui instituições e regimes formais investidos de poder para impor a observância das regras, do mesmo modo que arranjos informais que pessoas e instituições concordaram em estabelecer ou percebam ser de seu interesse.”
} 

a) demandas;
b) ordem do dia;
c) formulação;
d) decisão;
e) implementação;
f) impacto; e
g) avaliação.

A primeira fase, denominada demandas, corresponde à definição do problema e depende de fatores geográficos, históricos e, também, culturais. Significa dizer que aquilo que se apresenta como um problema ambiental para determinado grupo social, pode não possuir o mesmo conteúdo para outro grupo social. O mesmo autor exemplifica esta afirmativa com a poluição aquática que, para os europeus, representa um grande problema ambiental, enquanto, na América do Norte, há uma preocupação maior com a poluição atmosférica.

A fase da ordem do dia significa que o problema ambiental foi entendido como ensejador de um debate público, podendo chegar, ao final, a uma intervenção da autoridade administrativa competente. Evidente que o controle daquilo que se torna ordem do dia é um recurso político decisivo e depende do grupo social que detém o poder.

Por sua vez, as fases da formulação e decisão podem ser explicadas de uma maneira conjunta como a resolução do procedimento que será adotado para a consecução do objetivo maior de solucionar aquilo que foi considerado como um problema ambiental. Le Prestre chama a atenção dos leitores para o fato de que, tão 
importante quanto a decisão que se tomará frente ao problema ambiental, é o "como” tal decisão será tomada, e exemplifica com regras de votação, natureza dos atores implicados, tipos de consulta, tempo disponível, etc.

No tocante à implementação de uma política pública, cabe aqui a transcrição da definição precisa deste autor, que afirma:

\footnotetext{
"Por implementação entendemos as medidas tomadas pelos governos ou atores internacionais a fim de traduzir decisões - da legislação nacional ou de acordos internacionais - em um sistema de medidas jurídicas $e$ políticas, que assegurem a conformidade de seu comportamento com as normas adotadas." (LE PRESTRE, 2000, p.82)
}

Tomamos como exemplo exatamente este trabalho de dissertação, que analisa os principais instrumentos jurídicos e administrativos adotados pelo Brasil, após a assinatura e ratificação da Convenção da Diversidade Biológica e que, de alguma maneira, interpreta os objetivos e princípios da convenção mencionada e, ainda, analisa quais as instituições criadas com o fim de operacionalizar estas regras jurídicas e administrativas.

Por fim, os impactos referem-se aos efeitos que uma política pública provoca. Já o processo de avaliação destes impactos, aborda as funções preenchidas pela política e os efeitos, ainda que indesejados, que ela possa ter.

\subsection{O papel do Estado na questão ambiental}

As questões ambientais não podem ser resolvidas no âmbito exclusivo do setor privado, pois envolvem um grande número de atores sociais que necessitam da organização e força de um ente maior e legítimo. Equivale dizer que elas, por serem 
interdependentes, envolveriam um sem número de pessoas que, sozinhas, não seriam capazes de buscar soluções necessárias; estas, em geral, são contrárias ao interesse de determinados grupos. E também, tomar decisões dentro desta seara pressupõe um conhecimento científico do problema e suas possíveis conseqüências, sendo certo que apenas o Estado estaria disposto a arcar com os custos deste conhecimento prévio e necessário.

Walter Rosembaun (1977) afirma que caberá ao Estado, frente à questão ambiental: (i) identificar e definir o problema e os meios de ação; (ii) dar prioridade aos problemas ambientais na agenda pública; (iii) decidir sobre a repartição dos custos e arbitragens aceitáveis a fim de obter melhor qualidade do meio ambiente.

Não há uma doutrina geral, aplicável aos problemas ambientais, pois o estabelecimento da democracia como um sistema político assegurador das liberdades individuais não garante, por si só, a solução destes problemas. Isto também não quer dizer que o autoritarismo seja uma solução: o acesso à informação ou o direito de associação são exemplos de componentes de um sistema democrático, que certamente, auxiliam na percepção dos problemas e conseqüente estabelecimento das agendas políticas ambientais.

Paul E. Little (2003) assinala que a política ambiental deve-se desenvolver em diversos níveis: local, estadual, regional, nacional, continental e mundial. Esta diversidade de níveis apresenta-se como um desafio, uma vez que cada nível tem seus problemas ambientais próprios, e desta forma, atores sociais específicos para atendê-los. Portanto, as políticas públicas ambientais precisam ser moldadas para responder à especificidade de cada nível (LITTLE, 2003, p.13-25). 
Sem desconsiderar a importância dos demais níveis, a descentralização para tomada de decisões apresenta-se como necessária para que os problemas ambientais de amplitude local também possam ser resolvidos de maneira satisfatória. Se o desmatamento de uma área de preservação permanente, de aproximadamente 20 hectares, localizada dentro dos limites da zona rural de um pequeno município contribui, ao final, para o aquecimento global, antes e primeiramente, irá influir no regime de chuvas desta região, que por sua vez afetará os pequenos produtores locais.

A questão ambiental surge como um motivo a mais para que alguma descentralização se concretize. O estabelecimento de mecanismos de participação, também neste nível, impõe-se como um desafio.

Sobre o Sistema Nacional de Meio Ambiente, adotado pela Lei no 6.938/81, Edis Milaré assinalou:

\footnotetext{
"Na esfera do Estado, é necessário que haja uma réplica do que existe na esfera da União. Da mesma forma, na esfera do Município, é mister que se reproduza adequadamente o que existe na esfera estadual. Assim, paulatinamente, foram arquitetados e implantados os Sistemas Estaduais de Meio Ambiente e, em alguns poucos casos, os Sistemas Municipais de Meio Ambiente." (MILARÉ, 2004, p.20)
}

E Pedro Jacobi assevera:

\footnotetext{
"Embora os mecanismos para a democracia deliberativa relacionados com questões ambientais tenham avançado, ainda não incorporaram os grupos sociais normalmente excluídos dos mecanismos tradicionais de deliberação como atores que tem presença nos processos decisórios. Isto decorre do fato que estes grupos ainda não possuem os recursos econômicos, sociais e cognitivos que permitiriam sua participação ativa nas atividades que permeiam processos decisórios em torno de questões ambientais." (JACOBI, 2006)
} 
Mas é preciso ressaltar que a participação é elemento indissociável da informação. Políticas públicas de participação devem ser precedidas de programas de capacitação de pequenos e grandes grupos sociais.

Marina Silva, ao ser indicada como Ministra do Meio Ambiente, ressaltou a importância do movimento dos seringueiros a partir do final dos anos 1980. Tal movimento, que culminou com a morte de Chico Mendes, bem como outros movimentos locais que ocorreram na região norte de nosso país, contribuiu para que novos quadros e agentes políticos se formassem e disputassem espaço com as antigas oligarquias regionais. Políticas públicas visando o desenvolvimento local passam a ser implementadas, resultando em propostas econômicas e sociais alternativas para a região da Amazônia (SILVA, 2001).

\subsection{Algumas políticas ambientais brasileiras}

O estabelecimento de políticas públicas legitimadas apenas pelo sistema de representatividade e fundadas na autoridade formal demonstra-se ineficaz para a solução de problemas ambientais. Isso ocorre nas sociedades em geral e, particularmente, no Brasil. A participação da sociedade civil nas decisões de políticas públicas e também em sua implementação demonstra-se fundamental para que o acesso aos recursos naturais ocorra de forma eqüitativa.

Paulo Affonso Leme Machado (2006, p.88) aponta a participação como verdadeiro princípio do direito ambiental, já adotado explicitamente por constituições nacionais como a da Finlândia. 
No tocante à sociedade brasileira, a participação popular nos processos decisórios aumentou muito após a realização da Conferência das Nações Unidas para o Meio Ambiente e Desenvolvimento, no Rio de Janeiro, em 1992.

Um grande exemplo desta participação, que hoje ocorre de forma institucionalizada, foi a criação do Conselho Nacional do Meio Ambiente (CONAMA) que discute e delibera normas regulamentadoras da legislação ambiental em geral. Como exemplo do produto de trabalho deste Conselho, podemos citar a publicação da Resolução 302, de 20 de março de 2002, que dispõe sobre os parâmetros, definições e limites de Áreas de Preservação Permanente de reservatórios artificiais e o regime de uso do entorno.

Outro exemplo de participação popular, mas sem caráter deliberativo, foi a construção da Agenda 21 brasileira, que se deu por meio de processos de consulta nacional.

Esses exemplos corroboram a idéia de que apenas com o envolvimento pleno das partes interessadas da sociedade com os problemas ambientais se alcançará a governança, estabelecida como meta na Agenda 21 brasileira. Entretanto, é preciso atentar para o fato de que a qualidade da participação da sociedade depende do grau de consciência da população.

Conforme já apontado acima, não há dúvida de que a consciência socioambiental da população brasileira em geral evoluiu positivamente após a realização da Conferência das Nações Unidas para o Meio Ambiente e Desenvolvimento, no Rio de Janeiro, em 1992. A veracidade desta afirmativa pode ser confirmada, especificamente na questão da biodiversidade, pela realização de 
vários workshops e discussões, em diferentes regiões, com o envolvimento da comunidade acadêmica, populações moradoras das regiões, tradicionais ou não, e organizações não-governamentais.

O aumento do número de matérias tratando de questões ambientais, seja no rádio, televisão ou jornais, também aumentou significativamente. A divulgação de dados científicos por meio desses meios de comunicação em geral, com a utilização de uma linguagem mais acessível à população, tem influído na condução dos problemas ambientais. Uma vez que ciente dos perigos que corre, a população procura interferir nas decisões políticas.

Houve uma evolução também no aparato jurídico que sustenta o gerenciamento ambiental em nosso país. Leis importantes como a de Crimes Ambientais e a do Sistema Nacional de Unidades de Conservação são exemplos dessas normas.

O conceito de sociedade defendido por filósofos racionalistas como Hobbes, Kant e Locke baseia-se na necessidade do homem organizar-se socialmente para evitar a própria destruição. A existência de políticas públicas direcionadas à conservação ambiental é reflexo, em última instância, da necessidade de conservação do meio em que se vive para evitar a destruição da espécie humana.

O caminho para a participação nos processos decisórios ambientais está aberto, conforme exemplos expostos neste capítulo. Mas, isto não é o bastante. A sociedade deve estar preparada para esta participação.

Assim, as policy networks, ainda que em desenvolvimento gradual e mais importante nos últimos quinze anos no Brasil, são ainda incipientes para resolver 
conflitos ambientais. A conscientização e participação dos diversos setores da sociedade nas networks levarão, talvez, a um conjunto de dados que reflita melhor a realidade e, desta forma, contribua da melhor maneira para formulação de políticas públicas ambientais.

Os vários setores da sociedade envolvidos, no entanto, não deverão ter sua participação restrita à fase de formulação de políticas públicas. Igualmente importante será sua participação no processo de implantação destas políticas, posto que somente assim seja assegurado que os impactos e a avaliação das mesmas poderão refletir a realidade social nas quais estão inseridas. Nenhuma política pública tem sua eficácia determinada pelo Estado exclusivamente, mas também pela sociedade à qual se destina. 


\section{A CONVENÇÃO DA DIVERSIDADE BIOLÓGICA - A tutela jurídica da diversidade biológica}

Este trabalho reflete sobre parte das políticas públicas adotadas pelo Brasil por ser signatário da CDB. Neste sentido, é importante rever os conceitos de Convenção, Tratado e suas formas de adoção.

As principais causas de extinção da biodiversidade são aqui citadas para se entender porque a diversidade biológica passa a ser objeto de tutela jurídica, sendo elas: a existência e avanço das monoculturas, a degradação e perda de habitats, as mudanças climáticas e o avanço das espécies invasoras.

A seguir, apresenta-se uma descrição da CDB, com um histórico de eventos que culminaram na sua adoção, e seu funcionamento, enfatizando a descrição de seus componentes: Conferência das Partes Signatárias, Corpo Subsidiário de Assistência Técnica e Tecnológica e Mecanismo Financeiro.

O objeto desta dissertação é uma área protegida, a Reserva Extrativista do Baixo Juruá. Desta forma, os conceitos expressos nas letras “a” e "b” do Artigo 8, que tratam das áreas protegidas e das Unidades de Conservação, são tratados de maneira mais detalhada. Traz aos leitores os fatos ocorridos no âmbito da CDB referentes ao Grupo de Trabalho de Áreas Protegidas que fizeram surtir efeitos diretos no Brasil e que serão abordados no Capítulo seguinte. 


\subsection{A convenção como um conceito jurídico}

O Estatuto da Corte Internacional de Justiça tem como função decidir, de acordo com o direito internacional, as controvérsias que lhe são submetidas. Ele define, em seu artigo 38, as fontes formais do Direito, ou o modo pelo qual se tornam explícitas as normas jurídicas internacionais. Em seu rol estão presentes as convenções, o costume internacional, os princípios gerais de direito, as decisões judiciárias e a doutrina dos juristas mais qualificados das diferentes nações (Estatuto da Corte Internacional de Justiça).

Por sua vez, a Convenção de Viena sobre Direito dos Tratados, assinada em 23 de maio de 1969, regulamenta os processos de elaboração e os efeitos decorrentes dos atos internacionais bilaterais ou multilaterais - como é o caso da Convenção da Diversidade Biológica. A Convenção de Viena é, na verdade, uma consolidação dos princípios e normas vigentes entre os Estados, na maioria de fundo costumeiro. É reconhecida pela jurisprudência internacional sobre princípios e normas que regem a fonte primacial do Direito Internacional, que são os tratados e convenções interestatais.

A Convenção de Viena sobre Direito dos Tratados² define “tratado” como um acordo internacional celebrado entre Estados. Ele se apresenta de forma escrita e é regido pelo Direito Internacional, consistindo em um instrumento único, ou mais

\footnotetext{
${ }^{2}$ O Brasil, embora ainda não tenha ratificado a Convenção de Viena sobre o Direito dos Tratados de 1969, segue seus preceitos, pois a Convenção de Viena sobre o Direito dos Tratados de 1969 é reconhecida como regra declaratória de direito consuetudinário vigente, ou seja, é vigente, na forma de costume internacional, inclusive para os Estados que não a ratificaram, mas que reconhecem seus preceitos como obrigatórios. O Brasil é signatário da Convenção de Havana sobre Tratados, que possui um conteúdo similar ao de Viena, mas é de abrangência panamericana (ratificada pelo Brasil pelo Decreto n 18.956, de 22 de outubro de 1929).
} 
instrumentos conexos, qualquer que seja sua denominação. Portanto, qualquer que seja a denominação de um ato internacional multi ou bilateral como tratado, acordo, convenção, protocolo, pacto, estatuto, instrumento ou outros, será considerado um tratado no sentido da Convenção de Viena.

É importante ressaltar que, sendo considerado um tratado (seja qual for a denominação dada ao documento), estará subordinado ao artigo 26 da mesma Convenção que estabelece que todo tratado obriga as partes, que devem executá-lo de boa-fé.

Embora sejam documentos autônomos, os protocolos normalmente referemse a um tratado, adotado em data anterior à adoção destes. Por exemplo, o Protocolo de Cartagena sobre Biossegurança, assinado em 2000, está intimamente relacionado à Convenção da Diversidade Biológica assinada em 1992.

Outra diferenciação que se faz é aquela concernente às convenções-quadro. Trata-se de convenções propositadamente amplas e de conteúdo genérico, elaboradas dessa forma normalmente em função da mutabilidade dos fatos. Essas convenções, assim como uma grande moldura, traçam os limites normativos (ou espaço normativo) dentro dos quais os órgãos instituídos pela Convenção podem estabelecer leis especiais. Tal artifício permite que normas de esclarecimento e detalhamento do texto sejam criadas, sem ter de recorrer a procedimentos formais de renegociação.

A Convenção da Diversidade Biológica é um exemplo de convenção-quadro, sendo que o órgão legitimado à elaboração das leis especiais é a Conferência das Partes. Isto porque o artigo 23 da CDB estabelece que caberá a este órgão examinar e adotar protocolos e emendas à Convenção ou seus anexos. 
Atualmente, podemos observar uma tendência mundial à elaboração e assinatura de tratados internacionais do tipo quadro, em contraposição aos tratados convencionais. Isto se explica pelo fato de que toda e qualquer alteração interpretativa, extensiva ou restritiva, dos termos contidos no tratado convencional após a entrada em vigor deste documento deverá passar pelo procedimento solene das emendas. Em contrapartida, no tratado tipo quadro, deixa-se para o futuro as negociações sobre seu detalhamento sem, contudo, reabrir os procedimentos diplomáticos de reforma ou, ainda, adoção de outro tratado.

Ademais, hoje temos vários exemplos no campo do Direito Internacional do Meio Ambiente de tratados internacionais já assinados: por necessitarem de maiores conhecimentos técnicos indisponíveis no momento de sua assinatura para um melhor detalhamento e normatização, foram adotados como convenções-quadro. Tomando como exemplo a Convenção sobre Mudança de Clima, observamos que os atores internacionais, envolvidos na questão, aproveitaram um momento político propício à adoção desta convenção e deixaram para um momento posterior o detalhamento do texto e a elaboração de normas especiais, levando-se em conta a mutabilidade dos fatos (emissão de poluentes e aquecimento global) e a necessidade de se aprofundar os dados técnicos.

A esta tendência internacional, ou novo fenômeno no modo de elaboração das regras internacionais, Guido Soares (2001) denominou "uma nova engenharia normativa”. 


\subsubsection{Do procedimento para adoção de um tratado}

A doutrina internacionalista distingue quatro fases cronológicas para a elaboração de um tratado internacional:

a) negociação: é considerada negociação todo o período entre a proposta de negociação até a conferência diplomática para sua adoção;

b) assinatura e adesão;

c) entrada em vigor internacional;

d) implementação: assim entendida como execução ou aplicação.

As negociações de um tratado internacional ocorrem em reuniões formais e informais com delegados dos Estados, que são diplomatas ou peritos acreditados, e têm periodicidade e duração variáveis. Essas reuniões podem ter diversas denominações como comitês de negociação, painel intergovernamental, comitê intergovernamental de negociação e outros.

Cabe ressaltar que os atos multilaterais adotados pelos diplomatas no momento da negociação não são cogentes, ou seja, não implicam em uma sanção no caso de descumprimento.

Finda a negociação, adentra-se a fase da aprovação ou adoção do tratado, que normalmente se dá com a convocação de uma conferência ad hoc de assinatura dos tratados ou convenções multilaterais. A assinatura, ato formal pelo qual o Estado se vincula ao tratado ou convenção internacional, pode ser feita dentro de um período determinado, se isto estiver disposto no texto da convenção. Caso contrário, deverá 
ser feita pelo representante do Estado, com poderes específicos para tanto, ao final da conferência diplomática convocada para a aprovação.

No caso da Convenção da Diversidade Biológica, sabemos que foi assinada durante a realização da Conferência das Nações Unidas para o Meio Ambiente e Desenvolvimento, em 1992, no Rio de Janeiro. No entanto, seu texto já se encontrava em discussão desde 1991, desde a primeira reunião preparatória do Comitê Intergovernamental ad hoc.

A entrada em vigor do tratado ou convenção, no plano internacional, dependerá do que estiver disposto em seu texto, podendo ocorrer a vigência imediata após a assinatura ou condicionada a número definido de assinaturas e ratificações, ou ainda a outras disposições.

Especificamente no caso do Brasil, em face da norma contida no inciso VIII, do artigo 84 da Constituição Federal, apenas o Chefe do Poder Executivo tem competência para assinar um tratado internacional. Tal norma estabelece que o referido tratado só terá vigência em nosso país após sua ratificação, que é o ato pelo qual o Poder Legislativo aprecia e aprova o tratado.

Segundo Rezek, "ratificação é o ato unilateral com que o sujeito de direito internacional, signatário de um tratado, exprime definitivamente, no plano internacional, sua vontade de obrigar-se" (REZEK, 2000, p.50). Assim, os tratados internacionais, após a ratificação e expedição do decreto, passam a fazer parte do nosso ordenamento jurídico interno, vigorando plenamente e possuindo hierarquia de lei federal. Devem, portanto, ser aplicados pelos tribunais brasileiros da mesma maneira, extensão e obrigatoriedade própria à aplicação do direito interno. 
As advogadas Caroline Schmidt e Mariana Passos de Freitas (2006) afirmam que os juízes e desembargadores de nosso país pouco se utilizam das normas internacionais para fundamentar decisões, sendo tal assertiva comprovada pelo fato de que não há jurisprudência específica sobre a aplicação desses tratados. Prosseguem afirmando que tal fato advém até mesmo pela falta de conhecimento e desinteresse pelos tratados internacionais, que seriam menos importantes que as normas internas de nosso país.

Mas, em face da gravidade dos problemas ambientais que vivemos hoje, entendemos que todas as formas legais para a conservação dos recursos naturais devem ser utilizadas por quem é competente, devendo tal omissão ser observada e corrigida através dos cursos de formação dos magistrados.

\subsection{A biodiversidade como objeto de tutela jurídica}

A advogada e professora Cristiane Derani (1997) ensina que, além de suas funções primeiras de manutenção dos processos dos ecossistemas, os recursos naturais possuem um valor socioeconômico que nem sempre é fácil se visualizar. Este valor possui uma relação direta com o emprego dado ao recurso natural, ou seja, como este recurso é utilizado, de que forma, em que quantidade e com que freqüência, pela sociedade que o consome. A autora afirma: "Valorado, o recurso natural é um bem ambiental.” (DERANI, 1997, p.136)

A diversidade biológica, por ser um recurso natural, também é um bem ambiental. E por ser um bem ambiental, integra o mundo jurídico, deixando de ser um bem comum, para tornar-se um bem jurídico, podendo ter um caráter público ou 
privado. Em outras palavras, ela passou a integrar o mundo jurídico, como um objeto que necessita de sua tutela para continuar existindo, pois, do contrário, poderia ser explorada indiscriminadamente até o seu desaparecimento. Derani explica: “avalia-se a importância social de uma determinada fração da natureza, a fim de privilegiar determinadas condutas em relação a outras.” (DERANI, 1997, p.137)

Diversidade Biológica é o termo empregado para a variedade de formas de vidas na Terra. É o resultado de bilhões de anos de mudanças, moldada pelos diversos eventos naturais ocorridos e pela influência do homem, a partir de sua existência. Também consiste nas diferenças genéticas dentro das espécies e a variabilidade de ecossistemas (UNEP, 2000).

Boaventura Sousa Santos, Maria Paula de Meneses e João Arriscado Nunes asseveram no texto que abre o Volume 4 da obra "Semear Outras Soluções", com organização do próprio Boaventura:

\footnotetext{
“O termo 'biodiversidade', de fato, designa a diversidade de organismos, genótipos, espécies e ecossistemas, mas também os conhecimentos sobre essa diversidade. Embora não seja possível saber ao certo qual o número de espécies vivas existentes, as estimativas variam entre 5 a 30 milhões, ainda que alguns investigadores sugiram estimativas da ordem dos 80 milhões. Contudo, o número de espécies inventariadas e incluídas em bases de dados de acordo com convenções científicas internacionais não chega aos 2 milhões." (SANTOS et al., 2005)
}

A combinação das diversas formas de vida e sua interação com o meio ambiente fizeram da Terra o único lugar habitável, até hoje, para a espécie humana. A biodiversidade provém o sustento da vida humana porque dela obtemos comida, remédios, combustível, dentre tantos outros artigos. 
Por isto, a diversidade biológica é considerada o pilar de sustentação de nossa civilização: produtos advindos da natureza embasam diversos setores industriais, como o agroalimentar, de cosméticos, farmacêutico, de papel e de construção. Segundo o Jardim Botânico de Londres, a indústria farmacêutica movimenta em todo o mundo, com produtos derivados de recursos genéticos, cerca de US\$ 75 bilhões; a indústria de sementes, US\$ 30 bi; e em outros campos, mais de US\$ 60 bilhões (CUNHA, 2000).

A biodiversidade não é distribuída uniformemente pelo mundo, conforme anotado por Elliot (1998). Na verdade, concentra-se nos países tropicais, coincidentemente, considerados em desenvolvimento. Segundo esta autora, mais da metade de todas as espécies existentes no mundo vive em 6\% da superfície terrestre, a qual é coberta por florestas tropicais.

Ainda assim, as comunidades localizadas em diferentes partes do mundo relacionam-se de diferentes formas com os recursos naturais oferecidos pelos diferentes ecossistemas em que vivem. Com isto, diferentes regras culturais para a preservação dos recursos naturais foram criadas, acarretando a existência de áreas muito conservadas e outras absolutamente devastadas.

No mundo ocidental, a perda de diversidade de espécies e de indivíduos dentro das espécies tem um grande número de causas. A destruição de habitats por meio de alguns processos como a drenagem de áreas úmidas, a poluição e os impactos diretos e indiretos das mudanças climáticas, contribuem para a perda da diversidade biológica. Com isto, eles são alterados e o sustento derivado da diversidade biológica fica ameaçado. 
A “Revolução Verde” significou a substituição da cultura de centenas de milhares de plantas diferentes para a cultura de trigo e arroz, derivados de uma base genética muito restrita. A Índia cultivou mais de 30 mil variedades nativas ou autóctones de arroz. Entretanto, nos últimos quinze anos, houve uma drástica mudança na situação, sendo que o Instituto de Pesquisa da Agricultura Indiana prevê que esta enorme variedade não se restrinja a mais de 50 variedades (SHIVA, 2003).

Outro dado importante relativo à perda da biodiversidade é que o desaparecimento de uma espécie acarreta a extinção de inúmeras outras com as quais está inter-relacionada por meio de redes e cadeias alimentares. E, o que é pior, extinguem-se inúmeras espécies desconhecidas pelo homem, o que tornam absolutamente imprecisas as informações acerca das taxas de extinção de espécies. Atualmente, 1,75 milhão de espécies foram identificadas, a maioria delas de pequenas criaturas, como os insetos. Mas, presume-se que existam aproximadamente 3 a 100 milhões de espécies de plantas, animais e microorganismos (UNEP, 2000).

\subsubsection{Principais causas de extinção da biodiversidade}

O homem relaciona-se com o meio ambiente e transforma-o desde seu aparecimento na Terra. Não há, praticamente em todo planeta, uma área terrestre que não tenha sofrido a influência humana.

O homem, porém, não tem se relacionado com a natureza da mesma forma ao longo de sua existência. A mudança do sistema de coleta e caça de subsistência para a prática de cultivo de plantas e criação de animais significou uma revolução no modo de interação entre o homem e a natureza. 
A Revolução Industrial é outro importante marco na história do homem em relação à natureza.

\subsubsection{Substituição da biodiversidade por monoculturas}

Não se pode afirmar que a prática da agricultura seja uma atividade característica do homem contemporâneo. A irrigação, um dos pilares do desenvolvimento da prática da agricultura, surgiu há mais de cinco mil anos (BENSUSAN, 2006). Por muito tempo, pequenas populações humanas realizaram atividades de baixo impacto, funcionando como influenciadoras do meio em que viviam, mas também mantenedoras da biodiversidade.

Entretanto, na medida em que as populações cresceram e as tecnologias da agricultura se desenvolveram, o impacto da humanidade sobre o meio ambiente aumentou. O que se viu foi a devastação dos ambientes naturais e a conseqüente perda da diversidade biológica. Atualmente predomina a idéia de que a diversidade se opõe à produtividade, e verdadeiros impérios de monoculturas foram criados, como, por exemplo, a soja no Brasil.

A disseminação de monoculturas de variedades de alto rendimento na agricultura encontra fundamento na finalidade única de alta lucratividade, mas vai de encontro às idéias daqueles que percebem a diversidade como grande valor ecológico e social.

Segundo Shiva (2003), a idéia de alto rendimento eliminou os legumes e as sementes oleaginosas na Índia, que seriam essenciais para a nutrição e a fertilidade do solo. 


\subsubsection{Degradação e perda de habitats}

As áreas florestadas apresentam níveis de diversidade biológica sem paralelos, em relação às demais áreas do planeta. Embora cubram uma área menor que $10 \%$ da superfície da Terra, contêm pelo menos $90 \%$ das espécies do mundo todo (UNEP, 2002).

Tomando como exemplo uma área brasileira, podemos afirmar que a Amazônia contém mais vida selvagem que qualquer outra região da Terra. O enchimento do reservatório de Tucuruí, por exemplo, que inundou 2.150 quilômetros quadrados de floresta tropical úmida, representou a morte de inúmeras espécies de mamíferos, répteis e insetos. Nos moldes atuais, quanto mais o desenvolvimento se intensifica, maior a probabilidade de extinções.

O anúncio do Programa de Aceleração do Crescimento no ano de 2007 significa uma ameaça aos recursos naturais existentes na região Amazônica. A própria Ministra do Meio Ambiente, Marina Silva, assevera a importância do respeito às normas ambientais, ressaltando que a sociedade brasileira está farta da idéia de desenvolvimento a qualquer custo. Obras de infra-estrutura devem ser efetivadas, mas sabe-se que a adoção do modelo de desenvolvimento vigente acarretará na destruição daquela enorme reserva florestal, assim como já assistimos à destruição quase total da Mata Atlântica.

\subsubsection{Mudanças climáticas}

Durante a década de 1990, as mudanças climáticas surgiram como uma das maiores ameaças à perda da biodiversidade. O IPCC, ainda no relatório publicado 
em 2001, concluiu que as mudanças climáticas podem ser responsáveis por graves impactos nos ecossistemas e conseqüente perda de recursos naturais. Com o aquecimento global, alguns ecossistemas poderão desaparecer, enquanto outros mudarão substancialmente (IPCC, 2001).

No ano de 2007, o IPCC publicou novo relatório, desta feita bem mais pessimista do que o relatório de 2001. Segundo os cientistas, o aquecimento global e as mudanças climáticas chegaram a uma velocidade e com uma violência muito maiores do que cientistas e governantes previram. E a situação só tende a piorar, mesmo com medidas tomadas imediatamente (IPCC, 2007).

Ainda segundo o mesmo relatório, até o fim do século a temperatura na Amazônia deve subir $8^{\circ} \mathrm{C}-5^{\circ} \mathrm{C}$ a mais do que no resto do mundo. Isto significará a perda de $10 \%$ a $30 \%$ das espécies de plantas e animais.

\subsubsection{Espécies invasoras}

De acordo com a 6a . Conferência das Partes da CDB em Hague (2002), no item II de “Uso de Terminologias”, espécie exótica é toda espécie que se encontra fora de sua área de distribuição natural e espécie exótica invasora é aquela que, normalmente transportada pelo homem, coloniza outros ecossistemas que não o seu e ameaça ecossistemas, habitats ou espécies.

Tais espécies invasoras, por sua vantagem competitiva e favorecimento pela ausência de predadores e pela degradação dos ambientes naturais, dominam os nichos ocupados pelas espécies nativas, notadamente em ambientes frágeis e degradados. Representam uma enorme ameaça às espécies nativas, pois alteram os 
sistemas ecológicos da área não nativa, causando a alteração do hábitat de várias outras espécies e levando até a extinção de algumas.

Favorecidos pela destruição das barreiras biogeográficas em razão da ação antrópica, os processos de invasões biológicas tiveram uma forte aceleração. À medida que o homem foi colonizando novos ambientes, levou consigo plantas e animais domesticados, utilizados como fonte alimentar e de estimação. Desta forma, diversas espécies obtiveram condições de dispersão muito além de suas reais capacidades.

Com a crescente globalização e o conseqüente aumento do comércio internacional, espécies exóticas são translocadas, intencionalmente ou não, para áreas onde não encontram predadores naturais; com isto, tornam-se mais eficientes que as espécies nativas no uso dos recursos. Dessa forma, multiplicam-se rapidamente, ocasionando o empobrecimento dos ambientes, a simplificação dos ecossistemas e a própria extinção de espécies nativas.

Como exemplo, podemos citar um fato ocorrido há trinta anos: a introdução da perca do Nilo, Lates niloticus, no Lago Victória que, aparentemente, contribuiu para a extinção de 250 espécies endêmicas de peixes ciclídeos (UNEP, 2002).

A Convenção da Diversidade Biológica reconhece a questão das espécies invasoras como um problema mundial e convoca seus signatários a controlar ou erradicar as espécies invasoras que ameacem ecossistemas, habitats ou outras espécies na letra "h" do artigo $8^{\circ}$. 
De acordo com informações do Secretariado da $\mathrm{CDB}^{3}$, as espécies exóticas invasoras já contribuíram, desde o ano de 1600, com 39\% de toda extinção animal cujas causas são conhecidas. Adianta ainda o Secretariado da CDB que mais de 120 mil espécies exóticas de plantas, animais e microrganismos já invadiram os Estados Unidos da América, Brasil, Reino Unido, Austrália e Índia.

Considerando-se o número de espécies que já invadiram esses países, estimou-se que um total aproximado de 480 mil espécies exóticas já foram introduzidas nos diversos ecossistemas da Terra. Se imaginarmos que $20 \%$ a $30 \%$ dessas espécies introduzidas são consideradas pragas e que estas são as responsáveis pelos grandes problemas ambientais enfrentados pelo homem na agricultura, é fácil imaginar o tamanho do desafio que, forçosamente, enfrenta-se para o seu controle, monitoramento, mitigação e erradicação.

Por fim, conclui-se que as espécies exóticas invasoras representam um sério problema global e requerem respostas em todos os níveis de ação governamental. Em adição, e como parte da avaliação de risco, deve-se prever as possibilidades de espécies se tornarem invasoras, além do custo potencial, ecológico e econômico que podem causar.

\subsection{Convenção da Diversidade Biológica}

As diferenças nos processos de desenvolvimento econômico e na distribuição da biodiversidade, nos diversos países do mundo, demonstram a necessidade de estabelecimento de um sistema de proteção e valorização desta. Mas tal necessidade

\footnotetext{
${ }^{3}$ Disponível em http://www.mma.gov.br/invasoras/. Acesso em 15 de dezembro de 2007.
} 
é acompanhada, desde as primeiras reuniões internacionais que foram realizadas, de dificuldades jurídicas para o estabelecimento deste sistema.

Podemos verificar, atualmente, que a repartição da diversidade biológica mundial é, de modo geral, inversamente proporcional ao avanço tecnológico dos países que a detém. Com isto, temos um déficit de atuação nos avanços tecnológicos dos países detentores de uma grande biodiversidade.

Por outro lado, os recursos genéticos, que constituíam um bem de interesse ambiental para o mundo, hoje representam também um interesse econômico. Interesse este que cresce dia a dia, tornando a preservação dos recursos genéticos essencial.

A Convenção da Diversidade Biológica tem por origem um conjunto de iniciativas de estudiosos e pesquisadores que procuravam uma forma de regulamentar juridicamente, através de um instrumento internacional, a conservação da diversidade biológica no mundo.

O Programa das Nações Unidas para o Meio Ambiente (PNUMA) foi estabelecido em 1972 pela Assembléia Geral da Organização das Nações Unidas (ONU). Criado especificamente para implementar programas ligados à temática ambiental, apesar de não ter a força de organismos como a Organização das Nações Unidas para a Educação, a Ciência e a Cultura (UNESCO) ou Organização das Nações Unidas para a Agricultura e a Alimentação (FAO), surgiu como um braço importante da ONU na Conferência de Estocolmo em 1972. Apesar das duras críticas que recebe por sofrer a pressão dos países membros do Conselho de Segurança da ONU com poder de veto (que atuam na defesa de seus próprios 
interesses), o PNUMA merece destaque por ter promovido e continuar a promover as principais reuniões internacionais realizadas a partir de $1980^{4}$.

Dentro do PNUMA e com a participação da International Union for the Conservation of Nature (IUCN), constituiu-se um grupo de trabalho ad hoc com a finalidade de estudar a possibilidade de estabelecimento de uma convenção internacional que sistematizasse as atividades que, de alguma forma, envolvessem a diversidade biológica (COMEGNA, 2006).

Após a realização de algumas reuniões preliminares, o processo de negociação formal do trabalho teve início em 1991. Tinha por objetivo obter um texto de consenso para a Conferência das Nações Unidas para o Meio Ambiente e Desenvolvimento - CNUMAD, que viria a se realizar em junho de 1992, no Rio de Janeiro.

A Convenção da Biodiversidade, constituída por um preâmbulo, quarenta e dois artigos e dois anexos, um sobre identificação e monitoramento e outro em arbitragem e conciliação, foi aberta para assinaturas durante a Conferência das Nações Unidas para o Meio Ambiente e o Desenvolvimento, no Rio de Janeiro, no ano de 1992. No entanto, só entrou em vigência em 29 de dezembro de 1993. Este documento internacional aponta outras formas de se pensar a natureza ou novas formas de sua apropriação.

${ }^{4}$ RIBEIRO (2001) discute a formação do PNUMA e ZANIRATO e RIBEIRO (2007) tratam de como este organismo aborda a proteção das comunidades tradicionais em relação à UNESCO, à OMC e à OMPI. 
Segundo o diplomata brasileiro Geraldo Eulálio do Nascimento e Silva (1995), as discussões realizadas em Nairóbi, que antecederam a realização da Conferência do Rio de Janeiro, foram marcadas por fortes embates e prolongadas negociações entre o Norte e o Sul. De um lado, colocavam-se os países desenvolvidos (do Norte), que defendiam o acesso aos recursos naturais locados, em sua maioria, nos países do Sul. De outro lado, uniram forças os países detentores de maior diversidade biológica, a fim de obter acesso à tecnologia e aos recursos financeiros disponibilizados pelos países do Norte.

Ainda segundo Nascimento e Silva (1995), os Estados Unidos da América encabeçaram a lista dos países insatisfeitos com as medidas de proteção da propriedade intelectual para produtos de biotecnologia, em uma clara defesa de suas indústrias multinacionais. Tal posicionamento foi radicalizado quando este país negou-se a assinar a CDB durante a Conferência do Rio.

Mas, apesar das fragilidades apontadas, não se pode duvidar da importância da assinatura desta convenção. A CDB formalizou, à época em que foi assinada, novos conceitos como o uso sustentável da biodiversidade e a repartição justa e eqüitativa de benefícios advindos da utilização dos recursos genéticos.

Os objetivos da Convenção da Diversidade Biológica estão apontados no artigo $1^{\circ}$ e referem-se à conservação da diversidade biológica, ao uso sustentável de seus componentes e à repartição dos benefícios advindos da utilização dos recursos genéticos. No preâmbulo, encontramos a justificativa para tais objetivos, qual seja, o valor intrínseco da diversidade biológica que se traduz em seu valor ecológico, genético, social, econômico, científico, educacional, cultural, recreacional e estético. 
Depois de quase duas décadas da assinatura da CDB, infelizmente, não observamos um grande desenvolvimento das propostas referentes ao uso sustentável. Isto ocorre muito provavelmente porque os setores econômicos, em geral, não estão envolvidos verdadeiramente com a questão.

Já a repartição de benefícios apresenta-se como algo de difícil implementação, apesar das inúmeras tentativas de se tentar evitar que a biodiversidade transforme-se em mera mercadoria. Apesar disto, funciona como marco jurídico para a gestão da biodiversidade no mundo porque, no âmbito da realização das Conferências das Partes, vários outros instrumentos jurídicos tiveram origem. Como exemplo, podemos citar o Protocolo de Cartagena sobre Biossegurança, que estabelece as regras para a movimentação transfronteiriça de organismos geneticamente modificados (OGMs).

Por outro lado, a CDB foi responsável pela inserção do tema biodiversidade nas agendas dos países, incluindo o Brasil. A realização da $8^{a}$ Conferências da Partes em Curitiba, no ano de 2006, é exemplo desta inserção.

Até dezembro de 2007, 190 países assinaram a CDB. A ausência dos Estados Unidos da América continua a demonstrar a falta de comprometimento daquela nação com os objetivos assentados na CDB.

Em 2002, ou seja, 10 anos após a adoção da Convenção da Diversidade Biológica, foi desenvolvido um plano estratégico com o objetivo de garantir sua implementação nos níveis regional, nacional e internacional.

Pela complexidade do tema biodiversidade e alavancados pela adoção daquele tratado, os organismos internacionais têm-se organizado para obtenção de 
melhores resultados e promoção do processo de conservação da diversidade biológica de forma eqüitativa.

Neste sentido, o Programa de Desenvolvimento das Nações Unidas (UNDP) constitui-se em uma rede de desenvolvimento global que objetiva promover as mudanças necessárias e o intercâmbio de informações, conhecimentos e recursos naturais para melhorar a vida humana. Sob o suporte desta entidade constituem-se grupos de trabalho e Convenções internacionais, como é o caso do Global Environment Facility (GEF), que será analisado em subitem posterior, e da própria CDB, entre outros.

Em Fevereiro de 2002, constituiu-se o Grupo dos países megadiversos que possuem importantes heranças culturais, vitais para a conservação da biodiversidade (Like-minded Megadiverse Countries - LMMC), oficializado na Declaração de Cancun. Os 15 países constituintes deste grupo representam mais de $70 \%$ das espécies de plantas e animais no mundo, aproximadamente $45 \%$ da população mundial e a mais rica diversidade cultural. Isto permite aos países grande possibilidade de desenvolvimento, mas também uma enorme responsabilidade na conservação e sustentabilidade da biodiversidade. O Brasil está inserido neste grupo, que conta ainda com: África do Sul, Bolívia, China, Costa Rica, Colômbia, Equador, Filipinas, Índia, Indonésia, Malásia, México, Perú, Quênia e Venezuela ${ }^{5}$.

A Declaração de Cancun definiu uma agenda comum a estes países, no intuito de promover entre eles um mecanismo de interconsulta e cooperação científica,

\footnotetext{
${ }^{5}$ http://www.undp.org/biodiversity/partners.html - acesso em 15 de dezembro de 2007.
} 
sempre com o intuito de desenvolvimento de estratégias de conservação da biodiversidade sustentáveis. Essas estratégias devem considerar que os recursos advindos desta diversidade devem ser direcionados à redução da pobreza, promoção da saúde e manutenção das heranças culturais locais.

Uma das principais intenções declaradas pelo LMMC era a de criar um Fundo para suas ações através da ajuda da comunidade internacional. O Fundo de Cooperação para os países Megadiversos (MCF) foi oficialmente criado sob a administração da UNDP, para uso exclusivo do LMMC, em Janeiro de 2005 na reunião do LMMC em Nova Delhi, Índia ${ }^{6}$.

\subsection{O funcionamento da Convenção da Diversidade Biológica}

Para a efetiva implementação da Convenção da Diversidade Biológica, foi criada uma estrutura internacional formada, basicamente, por três elementos:

a) Conferência das Partes Signatárias da Convenção (COP);

b) Corpo Subsidiário de assistência Científica, Técnica e Tecnológica (Subsidiary Body on Scientific, Technical and Techonological Advice - SBSTTA);

c) Mecanismo financeiro (GEF);

\footnotetext{
${ }^{6}$ http://www.undp.org/biodiversity/docs/Summary_Report_Delhi_Megadiverse_17_21Jan05.doc acesso em 15 de dezembro de 2007.
} 


\subsubsection{Conferência das Partes Signatárias}

A Conferência das Partes é o corpo governante da Convenção, sendo que os avanços na implementação da Convenção, por meio de decisões, ocorrem durante seus encontros periódicos. Essas decisões são votadas durante as reuniões e tomadas normalmente por consenso, podendo votar os representantes oficiais dos países signatários. Representantes da sociedade em geral podem participar das COPs, mas apenas como observadores. A amplitude da Convenção se reflete na vasta agenda das COPs, podendo ser citadas como outras funções deste organismo a consideração dos relatórios nacionais, a adoção de protocolos e a condução do mecanismo financeiro.

Logo na primeira reunião que realizou, a Conferência das Partes estabeleceu um programa de trabalho relativo ao período 1995-1997. Com isto, foi possível desenvolver a estrutura necessária para o longo e difícil trabalho de implementação da própria Convenção que, todavia, não está perto do final.

No quarto encontro, realizado em 1998 (Bratislava, Slovakia), foi estabelecido um programa de trabalho a ser realizado até o sétimo encontro; mais importante, procedeu-se a uma revisão das operações relativas aos mecanismos de troca de informações e cooperação tratadas na Convenção. Como conclusão, recomendou-se que cada país signatário organizasse um comitê nacional de troca de informações e cooperação ou um grupo de trabalho composto por representantes multisetoriais e interdisciplinares, a fim de obter a ampla participação dos diversos atores responsáveis pelo processo de implementação dos referidos grupos de trabalho. 
Até o ano de 2007, foram realizadas nove reuniões ordinárias e um encontro extraordinário, no qual se estabeleceu as bases para a assinatura do Protocolo da Biossegurança. Até 1996 as reuniões ocorreram anualmente sendo que, com a mudança das regras a partir de 2000, foi estabelecido que ocorreriam apenas a cada dois anos.

Portanto, sendo a instância máxima da Convenção, a Conferência das Partes monitora a implementação da mesma.

\subsubsection{Corpo Subsidiário de Assistência Científica, Técnica e Tecnológica}

Estabelecido pelo artigo 25 da Convenção da Diversidade Biológica, o Corpo Subsidiário de Assistência Científica, Técnica e Tecnológica (SBSTTA) foi criado para reportar-se diretamente à COP, respondendo a suas demandas científicas, técnicas, tecnológicas e metodológicas. Desenvolve as seguintes funções: gerar avaliações técnicas e científicas do estado da biodiversidade, preparar análises técnicas e científicas das medidas tomadas para a implementação da CDB, identificar tecnologias e práticas inovadoras e eficientes com recomendação de formas de promover seu desenvolvimento e assistir programas científicos de cooperação internacional em pesquisa e desenvolvimento.

\subsubsection{Mecanismo Financeiro}

O mecanismo financeiro responsável pelo aporte financeiro para implementação da Convenção da Diversidade Biológica é o Fundo Global para o Meio Ambiente ou GEF (Global Environmental Facility). Composto por um 
conselho integrado por 32 países que representam os 176 países participantes do fundo, o GEF financia os projetos desenvolvidos pelas partes signatárias e pelas agências implementadoras do fundo, como o Programa das Nações Unidas para o Meio Ambiente (PNUMA), o Programa das Nações Unidas para o Desenvolvimento (PNUD) e o Banco Mundial.

Desde 1991, o GEF já investiu aproximadamente U\$ 4,1 bilhões em financiamentos e fundos conjuntos para a conservação da biodiversidade em países em desenvolvimento. ${ }^{7}$

Dentro do programa de biodiversidade, o GEF financia iniciativas que promovam a conservação in situ e o uso sustentável da biodiversidade em áreas protegidas. O GEF trabalha com governos e outros atores a fim de criar novas instituições, parceiros e acordos que contribuam para a consecução do fim maior, que é o desenvolvimento de todas as nações conservando-se seus recursos naturais.

Segundo dados expostos no programa eletrônico do GEF, os projetos referentes à biodiversidade abrangem 36\% (trinta e seis por cento) dos fundos de financiamento do GEF.

\subsection{Problemas e Vicissitudes da Convenção da Diversidade Biológica}

Entretanto, se a produção e assinatura da Convenção sobre a Diversidade Biológica pode ser apontada como um primeiro passo para a regulamentação jurídica de questões como diversidade biológica, biotecnologia e biossegurança, ela também

\footnotetext{
${ }^{7}$ http://www.gefweb.org/projects/Focal_Areas/bio/bio.html - acesso em 22 de fevereiro de 2007.
} 
é vista com restrições pelos países em desenvolvimento, alguns deles considerados megadiversos.

Há, certamente, algumas falhas no texto da Convenção, que claramente apontam para uma proteção dos direitos de propriedade intelectuais, arduamente defendidos pelas empresas multinacionais, principalmente relacionadas ao ramo farmacêutico e agro-alimentar (SHIVA, 2003).

A principal falha estaria presente no artigo $3^{\circ}$ da Convenção. Segundo este artigo os Estados, de acordo com a Carta Constitucional das Nações Unidas e com os princípios da lei internacional, têm o direito soberano de explorar seus próprios recursos em conformidade com suas próprias políticas ambientais. Tem também a responsabilidade de assegurar que as atividades, dentro de sua jurisdição ou controle, não causem danos ao meio ambiente de outros Estados ou de áreas além dos limites da jurisdição nacional.

Ainda segundo Shiva (2001), tal dispositivo não teria abarcado o direito soberano das comunidades locais que conservaram e preservaram a biodiversidade e cuja sobrevivência cultural está intimamente ligada à conservação e uso desta diversidade biológica.

Em que pese a preocupação social da autora, defendida na maioria de seus textos publicados, entendemos que a falha apontada talvez tenha sido suprida, ao menos parcialmente, pela letra “d”, do artigo 10, do mesmo texto. Segundo esta norma, as partes contratantes estão incumbidas de proteger e encorajar o uso habitual de recursos biológicos de acordo com as práticas culturais tradicionais que são compatíveis com os requisitos da preservação ou uso sustentável. 
Se esta disposição não abarcou explicitamente o princípio do direito soberano das comunidades tradicionais, como seria recomendável, ao menos de forma indireta pode ser usada para induzir as partes contratantes a produzirem normas internas nos países signatários com a mesma finalidade, qual seja, defender o direito das comunidades tradicionais quanto aos recursos naturais por elas usados e conservados.

Por outro lado, vários autores entendem o mesmo artigo $3^{\circ}$ como uma vitória dos países detentores de recursos genéticos, uma vez que a soberania, nas palavras de Wagner Ribeiro, por exemplo, foi destacada como um princípio no referido artigo, que estabelece:

\footnotetext{
"Os Estados, em conformidade com a Carta das nações Unidas e com os princípios do Direito Internacional, têm o direito soberano de explorar seus próprios recursos segundo suas políticas ambientais $e$ a responsabilidade de assegurar que atividades sob sua jurisdição ou controle não causem dano ao meio ambiente de outros Estados ou de áreas além dos limites da jurisdição nacional."8
}

Para Ribeiro, este artigo representa uma vitória para os países periféricos que, com seu passado colonial, conhecem inúmeros casos de dilapidação de seus recursos naturais, como pau-brasil, ouro, ferro e bauxita.

Como medida geral para a conservação in situ, que se refere à conservação de ecossistemas e habitats naturais e à manutenção e recuperação de populações viáveis de espécies em seus meios naturais, a CDB consagra em seu artigo $8^{\circ} \mathrm{o}$ estabelecimento de um sistema de Unidades de Conservação como um mecanismo

\footnotetext{
${ }^{8}$ Disponível em http://www.mma.gov.br/port/sbf/chm/capa/index.html.
} 
eficiente e tradicional para a conservação da biodiversidade nos diversos países signatários.

No caso do Brasil, por exemplo, como signatário desta Convenção, sua legislação deverá conferir poderes ao Governo - entenda-se Poder Executivo - para o desenvolvimento de suas ações em prol da conservação da diversidade biológica. Este embate pressupõe, certamente, a tentativa de se adequar e conciliar o interesse dos diversos atores sociais e econômicos envolvidos no cenário da diversidade biológica. Não se trata, certamente, de tarefa fácil.

Depois de vários anos da assinatura da CDB, vários programas temáticos foram criados e iniciativas globais foram encaminhadas. Entretanto, é unânime entre os estudiosos da conservação da biodiversidade a idéia de que a CDB apresenta, ainda, um baixo grau de implementação (BENSUSAN et al., 2006, p.13-28). Com base nesta constatação, na VI Conferência das Partes de 2002, foi criado um grupo de trabalho para estudar formas de promoção e implementação da CDB.

Porém, não se pode negar que a assinatura e os trabalhos para implementação da Convenção da Diversidade Biológica têm auxiliado e muito na árdua tarefa de conservação de um meio ambiente ecologicamente equilibrado para as presentes e futuras gerações. A disseminação da idéia de um desenvolvimento sustentável e a construção de uma rede de parceiros, graças à assinatura desta Convenção, têm ajudado no encaminhamento de ações globais visando à conservação da biodiversidade.

Ainda há muito a se fazer. O século XXI apresenta-se como um grande desafio a ser enfrentado pelos humanos: o consumo desenfreado, mudanças 
climáticas, redução da camada de ozônio e ameaças químicas são alguns dos exemplos de fatores que ameaçam as espécies e seus habitats.

A Convenção da Diversidade Biológica apresenta uma estratégia global para o enfrentamento das questões acima referidas. Entretanto, para se afastar a ameaça de extinção da vida humana na Terra, ou ainda, a ameaça de esgotamento dos recursos naturais, é necessário comprometimento. Comprometimento dos governantes dos países signatários deste acordo, bem como dos setores produtivos das sociedades em aplicar os conceitos consagrados na CDB, como a conservação da natureza, o uso sustentável da biodiversidade e a repartição justa e eqüitativa de benefícios advindos da utilização dos recursos genéticos.

Segundo o Planejamento Estratégico elaborado na 6a Conferência das Partes em 2002, há alguns pontos positivos no trabalho de implementação da CDB que merecem ser destacados.

Em primeiro lugar, não há como negar que a Convenção da Diversidade Biológica é responsável pela elaboração de uma agenda mundial relativa aos encaminhamentos da questão da diversidade biológica

Por outro lado, os Encontros das Partes, antes anuais e agora bianuais, proporcionam a tomada de decisões que colocam em prática os preceitos genéricos da Convenção. Segundo dados constantes no Planejamento Estratégico, políticas nacionais de conservação da biodiversidade foram adotadas em mais de 100 países, dentre os signatários.

Outra constatação feita pela Conferência das Partes em 2002 é que mesmo os países signatários em desenvolvimento possuem recursos disponíveis suficientes para 
implementar os três objetivos da Convenção, quais sejam: a conservação da biodiversidade, a utilização sustentável de seus componentes e a repartição justa e eqüitativa dos benefícios derivados da utilização dos recursos genéticos mediante, inclusive, o acesso adequado aos recursos genéticos e a transferência adequada de tecnologias pertinentes.

Segundo dados do mesmo relatório, a cooperação internacional, científica e técnica tem dado uma importante contribuição para construir tal capacidade.

Cristina Inoue complementa e pondera sobre a CDB, na obra Regime Global de Biodiversidade: o caso Mamirauá:

"A CDB pode ser considerada um dos pilares mais importantes do regime global de biodiversidade. Segundo Pimbert (1997, p.415), pela primeira vez um tratado internacional adota uma abordagem ampla, ao invés de setorial, sobre conservação e uso sustentável da diversidade biológica da Terra. Contudo, pouco progresso foi alcançado em desacelerar a perda da diversidade biológica no mundo. Se ela for avaliada em termos de efetividade, ou das respostas dos estados, refletindo na sua incorporação à legislação doméstica e às políticas públicas implementadas, os resultados são pouco expressivos. As negociações são lentas e difíceis sempre que a COP se encontra buscando acordo sobre a sua implementação.” (INOUE, 2007, p.72)

Para a autora, prevalecem as dificuldades de aplicação da CDB. No caso brasileiro, isso pode ser comprovado com esta pesquisa. Mesmo com a criação de uma RESEX nos moldes da CDB, ela carece de infra-estrutura e pessoal para fazer valer a proteção da biodiversidade e seu aproveitamento pelas comunidades que nela vivem. 


\title{
3.6 Artigo $8^{\circ}$ - A importância das áreas protegidas segundo a CDB
}

\author{
O artigo $8^{\circ}$ da Convenção da Diversidade Biológica estabelece in verbis:
}

Artigo 8 - Conservação “in situ”

Cada Parte Contratante deve, na medida do possível e conforme o caso:

(a) Estabelecer um sistema de áreas protegidas ou áreas onde medidas especiais precisem ser tomadas para conservar a diversidade biológica;

(b) Desenvolver, se necessário, diretrizes para a seleção, estabelecimento e administração de áreas protegidas ou áreas onde medidas especiais precisem ser tomadas para conservar a diversidade biológica;

(c) Regulamentar ou administrar recursos biológicos importantes para a conservação da diversidade biológica, dentro ou fora de áreas protegidas, a fim de assegurar sua conservação e utilização sustentável;

(d) Promover a proteção de ecossistemas, hábitats naturais e manutenção de populações viáveis de espécies em seu meio natural;

(e) Promover o desenvolvimento sustentável e ambientalmente sadio em áreas adjacentes às áreas protegidas a fim de reforçar a proteção dessas áreas;

(f) Recuperar e restaurar ecossistemas degradados e promover a recuperação de espécies ameaçadas, mediante, entre outros meios, a elaboração e implementação de planos e outras estratégias de gestão;

(g) Estabelecer ou manter meios para regulamentar, administrar ou controlar os riscos associados à utilização e liberação de organismos vivos modificados resultantes da biotecnologia que provavelmente provoquem impacto ambiental negativo que possa afetar a conservação $e$ a utilização sustentável da diversidade biológica, levando também em conta os riscos para a saúde humana;

(h) Impedir que se introduzam, controlar ou erradicar espécies exóticas que ameacem os ecossistemas, hábitats ou espécies; 
(i) Procurar proporcionar as condições necessárias para compatibilizar as utilizações atuais com a conservação da diversidade biológica e a utilização sustentável de seus componentes;

(j) Em conformidade com sua legislação nacional, respeitar, preservar e manter o conhecimento, inovações e práticas das comunidades locais e populações indígenas com estilo de vida tradicionais relevantes à conservação e à utilização sustentável da diversidade biológica e incentivar sua mais ampla aplicação com a aprovação e a participação dos detentores desse conhecimento, inovações e práticas; e encorajar a repartição eqüitativa dos benefícios oriundos da utilização desse conhecimento, inovações e práticas;

(k) Elaborar ou manter em vigor a legislação necessária e/ou outras disposições regulamentares para a proteção de espécies e populações ameaçadas;

(l) Quando se verifique um sensível efeito negativo à diversidade biológica, em conformidade com o art. 7, regulamentar ou administrar os processos e as categorias de atividades em causa; $e$

(m) Cooperar com o aporte de apoio financeiro e de outra natureza para a conservação in situ a que se referem as alíneas (a) a (l) acima, particularmente aos países em desenvolvimento.

Como se observa do artigo supra transcrito, a Convenção da Diversidade Biológica demonstrou especial atenção à chamada conservação in situ. Dedicou, para tanto, 5 letras do artigo $8^{\circ}$ para normatizar tal tema. Desta forma, determinou aos países signatários que estabeleçam e mantenham um eficiente sistema nacional de áreas protegidas em seus países.

Segundo documento publicado pela União Internacional para Proteção da Natureza em 1994, podemos definir uma área protegida ou uma Unidade de Conservação como "uma superfície de terra ou mar consagrada à proteção e manutenção da diversidade biológica, assim como dos recursos naturais e dos 
recursos culturais associados, e manejada através de meios jurídicos e outros eficazes.” (UICN, 1994, p.185)

Por sua vez, o artigo $2^{\circ}$ da Convenção da Diversidade Biológica, que traz as definições dos termos utilizados neste tratado internacional, define área protegida como aquela determinada geograficamente e destinada (ou regulamentada) e administrada para alcançar objetivos específicos de conservação.

Em face do aumento das taxas de perda da biodiversidade em razão das causas acima expostas, percebemos, hoje, um aumento do número de áreas naturais protegidas estabelecidas. Segundo dados do Grupo de Trabalho da CDB sobre Áreas Protegidas (tratado no subitem abaixo), o total de áreas protegidas em quilômetros quadrados aumentou no mundo todo de menos três milhões em 1970 para mais de vinte milhões em $2004^{9}$.

Este aumento, certamente, não se trata de um fato isolado, mas sim mais um reflexo da evolução do pensamento e do movimento mundial pela conservação da natureza. Tal movimento pode ser explicado e relatado pelas diversas reuniões internacionais que tinham como objetivo a discussão de medidas a serem tomadas para se evitar a deterioração dos ambientes naturais.

Segundo MacKinnon et al. (1986), é preciso que os sistemas naturais de áreas protegidas representem a biodiversidade dos países, respondendo, desta forma, às necessidades de conservação. A análise desses sistemas permitirá ao país avaliar seu grau de compromisso para com a conservação.

${ }^{9}$ http://www.cbd.int/protected/intro.shtml - acesso em 16 de dezembro de 2007. 
Comprovando a preocupação da Convenção da Diversidade Biológica com as áreas especialmente protegidas, temos que o GEF, ou o mecanismo financeiro da convenção, já investiu em mais de 1.500 áreas protegidas. Cobriu, desta forma, 300 milhões de hectares em todo o mundo. Até 2006, contribuiu com mais de U\$1,5 bilhão para financiar áreas protegidas, focando sempre nos projetos que englobassem sistemas nacionais de áreas protegidas e não áreas protegidas individualmente consideradas. ${ }^{10}$

\subsubsection{Grupo de Trabalho da CDB sobre Áreas Protegidas}

Em seu sétimo encontro, realizado em 2004 em Kuala Lumpur, Malásia, a Conferência das Partes decidiu criar um programa de trabalho especialmente voltado para as áreas protegidas. Este programa, estabelecido na decisão VII/28, tem por objetivo o estabelecimento e a manutenção de sistemas nacionais e regionais de áreas protegidas efetivos e ecologicamente representativos, tendo sempre como meta final a diminuição das atuais taxas de perda da biodiversidade dos países signatários.

Para tanto, foi criado um Grupo de Trabalho de áreas protegidas para dar suporte e supervisionar a implementação do programa de trabalho acima referido. Estabeleceu-se, então, que este grupo de trabalho reunir-se-ia nos dias 13 a 17 de julho de 2005 em Montecatini, na Itália.

Este grupo de trabalho foi subdividido em dois subgrupos, que ficaram abertos à participação de todos os países signatários e partes da Convenção.

\footnotetext{
${ }^{10}$ http://www.gefweb.org/projects/Focal_Areas/bio/bio.html - acesso em 22 de fevereiro de 2007.
} 
O primeiro subgrupo foi incumbido de trabalhar nas questões relativas ao estabelecimento de áreas marinhas protegidas, além dos limites nacionais de jurisdição dos países.

Ao subgrupo II, couberam as questões relativas à busca de opções para obtenção de recursos financeiros, necessários para implementação do programa de trabalho de áreas protegidas nos países em desenvolvimento. Dentro desta seara, deveria este subgrupo revisar as considerações de todos os governos das partes signatárias acerca da implementação do programa de trabalho em áreas protegidas, bem como procurar novos caminhos para esta implementação.

Para a consecução dos objetivos deste programa de trabalho, a Secretaria Executiva da Convenção elaborou vários relatórios que subsidiaram os trabalhos dos grupos e seus subgrupos.

O primeiro deles (UNEP/CBD/WG-PA/1/INF/1) ${ }^{11}$ foi uma análise dos sistemas marinhos e que incluiu informações quanto à distribuição e status desses ecossistemas, bem como as ameaças a que estão submetidos. Tal documento teve como objeto os recifes de corais, cadeias submarinhas, ventos hidrotermais e áreas de alta produtividade e biomassa. Obteve-se, desta forma, uma análise espacial dos hotspots de biodiversidade em áreas marinhas. Tais informações deveriam subsidiar futuros trabalhos de cooperação entre países signatários dirigidos à conservação e ao uso sustentável dos recursos marinhos.

\footnotetext{
${ }^{11}$ http://www.biodiv.org/doc/meeting.aspx?mtg=PAWG-01
} 
O segundo trabalho (UNEP/CBD/WG-PA/1/INF/2), também do subgrupo I, conteve uma revisão do regime legal existente e incidente sobre áreas marinhas, tratando tanto dos instrumentos legais globais quanto locais.

Para subsidiar os trabalhos do subgrupo II, a Secretaria Executiva da Convenção providenciou um processo de revisão das principais informações publicadas acerca de financiamentos concedidos a projetos relativos a áreas protegidas por agências multilaterais, fundações privadas e organizações não governamentais (UNEP/CBD/WG-PA/1/3). E ainda, relativamente a este subgrupo, a Secretaria Executiva elaborou um documento (UNEP/CBD/WG-PA/1/4) contendo informações que identificassem as falhas relativas ao programa de trabalho, no que concerne às áreas protegidas.

Assim, em 13 de junho de 2005 em Montecatini, na Itália, ocorreu a primeira reunião do Grupo de Trabalho de áreas protegidas da Convenção da Diversidade Biológica. Este encontro foi relatado no documento UNEP/CBD/WG-PA/1/6 e abaixo destacamos as principais recomendações adotadas pelo Grupo de Trabalho sobre áreas protegidas.

No que concerne às opções de cooperação para o estabelecimento de áreas protegidas em mares abertos, ou seja, fora de limites nacionais de jurisdição, o grupo reconheceu que a Convenção Internacional sobre Direito do Mar iniciou a construção de uma estrutura jurídica que regulamentou as atividades oceânicas, mas precisa ser complementada urgentemente. Definiu também a necessidade da Secretaria executiva em compilar uma lista dos critérios ecológicos existentes para 
identificação de sistemas de classificação biogeográfica e recursos marinhos potenciais que necessitem de proteção.

Mais ainda, clamou as partes signatárias para que tomassem medidas urgentes de proteção aos recifes de corais e cadeias subaquáticas sob sua jurisdição e controle, a fim de que novos danos não ocorram.

Anotou, por fim, o fato de que o estudo científico acima citado, UNEP/CDB/WG-PA/1/INF/1, elaborado pela Secretaria Executiva, ainda precisa ser complementado por novos dados e especificamente nos estudos de:

a) distribuição de todas as espécies listadas como ameaçadas de extinção;

b) funções e espécies associadas aos ecossistemas de cadeia de corais e cadeias subaquáticas;

c) ecologia e comportamento das espécies marinhas, os quais justifiquem sua vulnerabilidade em relação à atividade humana;

d) informações sócio-econômicas relativas ao uso dos recursos marinhos em relação a comunidades locais;

e) e informações sobre a evolução de espécies marinhas.

A participação ativa dos atores envolvidos em fornecer dados que substanciem tais apreciações esteve abaixo do esperado por ocasião desta reunião, o que justifica em parte a extensão desta lista de informações requeridas.

Tais ações deveriam ser complementares às atividades já desenvolvidas para a preservação de biodiversidade marinha em territórios sob jurisdição nacional, que é 
bastante rica e oferece muitas oportunidades para a promoção destas áreas protegidas.

Ressalta que atividades como a pesca ilegal é uma das maiores ameaças a este fim, devendo ser combatida em nível nacional e internacional por meio de cooperação entre as partes.

Como relatado anteriormente, os esforços para a implementação das diretrizes estabelecidas pela CDB são ainda incipientes entre os países signatários. Não se deve esquecer que, neste contexto, interesses nacionais e econômicos parecem ditar o ritmo desta implementação ante a necessidade mundial de conservação da biodiversidade para a preservação da espécie humana. Certamente, a não participação dos Estados Unidos da América como signatário desta Convenção determina impacto negativo importante, posto que sua economia interfere diretamente na esfera internacional.

A Conferência das Partes em 2002 concluiu que os países signatários em desenvolvimento possuem recursos disponíveis suficientes para implementar a conservação da biodiversidade, a utilização sustentável de seus componentes e a repartição dos benefícios derivados da utilização dos recursos genéticos, contando para tal com a cooperação internacional científica e técnica. No entanto, a atuação do GEF corrobora a necessidade de ajuda financeira internacional para que tais objetivos sejam alcançados, tendo em vista que a utilização econômica da biodiversidade é uma importante fonte de renda mundial.

Ainda neste sentido, a criação do MCF destinado aos LMMC deve ampliar esta ajuda financeira. Em que pese o fato do MCF ser administrado por entidade 
subordinada à ONU (UNDP) e, portanto, sofrer forte influência dos países desenvolvidos, a comunidade internacional aprova e entende que tal assistência financeira é fundamental para a implantação das estratégias de conservação da biodiversidade.

Conforme apontado, é controverso se pequenas alterações no texto da Convenção significariam grande aumento nos benefícios dos países detentores da diversidade biológica. Ressalte-se, no entanto, que a CDB representou um marco e contribuiu para a elaboração de uma agenda mundial para discussão da biodiversidade.

Ainda aquém do nível desejado, as propostas ainda são duramente rechaçadas por países desenvolvidos, como os Estados Unidos, por exemplo. Mas o caminho das negociações nunca foi curto e, portanto, deve ser arduamente percorrido. 


\section{A IMPLEMENTAÇÃO DA CDB NO BRASIL}

Segundo as normas brasileiras, o texto de uma convenção internacional deverá ser aprovado pelo Poder Legislativo, por meio de um decreto legislativo, e promulgado pelo Poder Executivo que o ratificará. No caso da CDB, seu texto passou a integrar o sistema jurídico brasileiro em 1998, ano de promulgação do Decreto $\mathrm{n}^{0}$ 2.519, de 16 de março de 1998.

Desta forma, várias obrigações foram assumidas pelo Poder Público. Alguns conceitos importantes para a conservação ambiental em geral e, especificamente, para a conservação da diversidade biológica foram definidos no texto da convenção e, conseqüentemente, consagrados pelo decreto.

Coube ao Ministério do Meio Ambiente, órgão da administração direta, a incumbência de elaborar políticas públicas que visassem o cumprimento desses compromissos do Brasil como país signatário da Convenção sobre Diversidade Biológica.

Esta estratégia engloba programas e políticas, algumas delas, entendidas como primordiais, que serão descritas e analisadas a fim de que o leitor possa obter um retrato do que foi feito por nossos governantes para a conservação da diversidade biológica do país, após a ratificação da Convenção. 
Tal estratégia se demonstra vital, já que o Brasil abriga a maior diversidade biológica entre os 17 países "megadiversos", os quais reúnem 70\% das espécies animais e vegetais catalogadas até o presente no mundo. As estimativas são de que o Brasil tenha entre 15 e $20 \%$ de toda a diversidade biológica mundial e o maior número de espécies endêmicas do globo - um importante recurso, seja pelos serviços ambientais mantidos por esta biodiversidade, seja pelas oportunidades de desenvolvimento e uso sustentável gerados por ela (MMA, 1998).

A "megadiversidade" cultural é representada por mais de 200 povos indígenas, com 170 línguas, e por um grande número de comunidades locais (povos indígenas, quilombolas, caiçaras e caboclos) que detêm um considerável conhecimento das espécies de flora e fauna e dos sistemas tradicionais de manejo dos recursos naturais renováveis. A contribuição desses povos e comunidades é fundamental para a conservação e uso sustentável do patrimônio biológico e genético do Brasil. A estes povos devem se reverter, de maneira eqüitativa, os benefícios advindos dessa exploração.

Serão apresentados, ainda, neste Capítulo, os Relatórios Nacionais para a Conservação da Biodiversidade do Brasil entregues ao Secretariado da CDB, onde consta o grau de implementação da CDB no país.

Por fim, será feita uma análise específica da implementação das letras “a” e “b”, do artigo 8, da CDB, que tratam notadamente das áreas protegidas. Neste item, optou-se por uma apresentação cronológica de algumas políticas públicas que têm por objeto, especificamente, as áreas protegidas. 


\subsection{Ministério do Meio Ambiente e a Conservação da Diversidade Biológica}

O Ministério do Meio Ambiente (MMA), órgão da administração direta, criado em 1992, com a publicação da Lei $n^{0}$ 8490, tem por competência a atuação nas seguintes áreas: política nacional do meio ambiente e dos recursos hídricos, política de preservação, conservação e utilização sustentável de ecossistemas, biodiversidade e florestas, proposição de estratégias, mecanismos e instrumentos econômicos e sociais para a melhoria da qualidade ambiental e o uso sustentável dos recursos naturais, políticas para a integração do meio ambiente e produção, políticas e programas ambientais para a Amazônia Legal e zoneamento ecológico (BRASIL, 2007).

Como se observa, é o braço do governo responsável diretamente pela elaboração e implementação de políticas públicas que tenham por objeto questões ambientais.

Após sua criação em 1992, o MMA teve a primeira Estrutura Regimental aprovada pelo Decreto no 1.205, de $1^{\text {o }}$ de agosto de 1994, quando era Ministro o Sr. Henrique Brandão Cavalcanti. Naquele momento o MMA foi dividido nas seguintes Secretarias: Secretaria de Coordenação dos Assuntos do Meio Ambiente, Secretaria de Coordenação da Amazônia Legal e Secretaria de Coordenação de Assuntos de Desenvolvimento Integrado.

Destaca-se aqui, a preocupação com o bioma Amazônia, que recebeu uma Secretaria especialmente incumbida de articular políticas visando à conservação de seus recursos naturais. 
Até 2007, o MMA sofreu alterações em sua estrutura regimental, por meio dos seguintes decretos:

- $\quad$ Decreto 2.619, de 09 de junho de 1998;

- $\quad$ Decreto 2.972, de 26 de fevereiro de 1999;

- $\quad$ Decreto 4.755, de 20 de junho de 2003;

- $\quad$ Decreto 5.776, de 12 de maio de 2006;

- $\quad$ Decreto 6.101, de 26 de abril de 2007.

A Secretaria de Biodiversidade e Florestas foi criada como uma das secretarias do Ministério do Meio Ambiente no ano de 1999, por meio da publicação do Decreto $n^{0}$ 2.972, conforme descrição das alterações feita acima. Nessa alteração da estrutura regimental do Ministério foram criadas as seguintes secretarias: Secretaria de Qualidade Ambiental nos Assentamentos Humanos, Secretaria de Biodiversidade e Florestas, Secretaria de Recursos Hídricos, Secretaria de Políticas para o Desenvolvimento Sustentável, Secretaria de Coordenação da Amazônia, Instituto de Pesquisas Jardim Botânico do Rio de Janeiro.

Observa-se com a alteração de 1999 um arranjo estrutural do Ministério muito parecido com o que se tinha até 2006. Algumas Secretarias mudaram de nome, mas possuíam atribuições muito parecidas com aquelas que lhes foram delegadas em 1999. Era o caso da Secretaria de Qualidade Ambiental nos Assentamentos Humanos, por exemplo, que era denominada até 2006 de Secretaria de Qualidade Ambiental.

Já a alteração de 2007, significou uma grande mudança na estrutura regimental daquele órgão, com uma grande reorganização dos departamentos. 
Com a publicação do Decreto $n^{\circ}$ 6.101, de 26 de abril de 2007, foram então criadas, no âmbito do Ministério e subordinadas diretamente ao Gabinete do Ministro do Meio Ambiente, a Secretaria de Mudanças Climáticas e Qualidade Ambiental, Secretaria de Biodiversidade e Florestas, Secretaria de Recursos Hídricos e Ambiente Urbano, Secretaria de Extrativismo e Desenvolvimento Rural Sustentável, Secretaria de Articulação Institucional e Cidadania Ambiental.

\subsubsection{A Secretaria de Biodiversidade e Florestas}

A Secretaria de Biodiversidade e Florestas tem como objetivo promover com participação, inclusão social e repartição dos benefícios - a valorização, a conservação e o uso sustentável da biodiversidade e dos conhecimentos tradicionais associados, dos recursos florestais, faunísticos, florísticos, pesqueiros e genéticos dos ecossistemas, bem como a remuneração pelos serviços ambientais por eles prestados.

É constituída por quatro departamentos: Departamento de Conservação da Biodiversidade, Departamento de Florestas, Departamento de Áreas Protegidas e Departamento do Patrimônio Genético. Essas divisões já existiam no âmbito da Secretaria, mas cada célula era denominada de Diretoria.

Segundo o Quadro Demonstrativo dos Cargos em Comissão e das Funções Gratificadas do Ministério do Meio Ambiente o Gabinete da Secretaria da Biodiversidade e Florestas é constituído por 1 Secretário, 6 Gerentes de Projetos, 1 Chefe de Gabinete, 2 Assessores Técnicos, 4 Assistentes e1 Assistente Técnico (BRASIL, 2007a e 2007b). 
Conforme o nome do quadro explicita, tais cargos são tidos em comissão, ou seja, podem ser ocupados por pessoas que não sejam servidores públicos, não havendo qualquer concurso de ingresso para assumirem tais funções. E além desses cargos, todos os servidores públicos lotados no Ministério do Meio Ambiente podem integrar o Gabinete ou as Diretorias e seus departamentos, da forma que as chefias entenderem por bem.

Ao Ministério do Meio Ambiente (MMA) cabe executar a parte do programa de governo que tem por objetivo a solução de conflitos que envolvam questões ambientais. E, conforme explicitado no Capítulo 3 deste trabalho, para a execução de um programa de governo, pressupõe-se a existência de um financiamento.

A professora e geógrafa Neli Aparecida de Mello explica que, apesar de ter ocorrido um crescimento no número de Unidades de Conservação no Brasil, houve uma redução dos orçamentos públicos de instituições responsáveis pela gestão destas unidades. Especifica que o Instituto Brasileiro do Meio Ambiente e dos Recursos Naturais Renováveis (IBAMA), autarquia diretamente ligada ao Ministério do Meio Ambiente e responsável pela administração das Unidades de Conservação federais do Brasil, dispunha, em 1989, de um orçamento de US\$ 21 milhões, valor este que foi reduzido em 1992 para US\$ 4 milhões. Segundo a autora, essa perda se refletiu na capacidade de manutenção e gestão das áreas protegidas. A demonstração de seus dados aponta que, em 1995, os gastos com as unidades eram de R\$ 29,5 milhões e em 1999 foram reduzidos para R\$ 5,3 milhões (MELLO, 2006). 
Ainda após a virada do século, segundo estudo realizado, no ano de 2006, pela Conservation Internacional ${ }^{12}$ (CI-Brasil), os recursos orçamentários do governo federal para a área do meio ambiente acumularam perdas no período entre 2000 e 2005 e comprometeram programas para a política ambiental do país.

Segundo este estudo, a despeito do orçamento do MMA apresentar um aumento “no papel” de 41\% no período, passando de R\$ 1,62 bilhões, em 2000, para R\$ 2,28 bilhões, em 2005, o valor efetivamente gasto (empenhado), de R \$ 1,17 bilhões, é $10 \%$ inferior ao montante investido cinco anos atrás. Observa-se, então, que o principal braço do governo federal na área ambiental, o Ministério do Meio Ambiente e, conseqüentemente, suas autarquias, vê-se comprometido pelo baixo orçamento.

Retornando ao funcionamento do Ministério e sua estruturação, temos que o Departamento de Conservação da Biodiversidade funcionava até a publicação do Decreto 6.101, de 26 de abril de 2007, como Diretoria do Programa Nacional de Conservação da Diversidade Biológica (DcBio).

Apesar de o nome ter sido alterado, continua a ter como objetivos a formulação de políticas e normas para a conservação e uso sustentável da biodiversidade, a disseminação de informações sobre biodiversidade, o estabelecimento de um sistema de acesso a recursos genéticos e o estímulo à conservação e utilização sustentável da biodiversidade, nos setores público e privado.

\footnotetext{
${ }^{12}$ http://www.conservation.org.br/noticias/noticia.php?id=201 - acesso em 07 de agosto de 2007.
} 
Da mesma forma, com a publicação do decreto, a antiga Diretoria do Programa Nacional de Áreas Protegidas teve seu nome alterado para Departamento de Áreas Protegidas. Este tem como objetivos básicos a formulação de políticas e normas para a ampliação e consolidação do Sistema Nacional de Unidades de Conservação e outras áreas especialmente protegidas, assim como a formulação de políticas públicas para a gestão de Unidades de Conservação e outras áreas protegidas. O Departamento tem agora suas atenções voltadas para a articulação e desenvolvimento institucional do Plano Estratégico Nacional de Áreas Protegidas.

Observa-se aqui, vários pontos em comum com os objetivos de outro órgão da administração federal, o recém criado Instituto Chico Mendes de Conservação da Biodiversidade, criado por meio da Lei $n^{0}$ 11.516/07, que tem por atribuição, executar ações da política nacional de Unidades de Conservação da natureza, referentes às atribuições federais relativas à proposição, implantação, gestão, proteção, fiscalização e monitoramento das Unidades de Conservação instituídas pela União (BRASIL, 2007c).

A antiga Diretoria do Programa Nacional de Florestas funciona hoje como Departamento de Florestas. A ele compete, em síntese, formular políticas públicas a temas relacionados a promoção, em bases sustentáveis, de implantação de plantios florestais e de sistemas agroflorestais, promoção de recuperação de áreas degradadas e promoção do manejo sustentável de florestas nativas para a geração de produtos madeireiros e não madeireiros e coordenar o Programa Nacional de Florestas.

Por último, cabe ao Departamento de Patrimônio Genético, antiga Diretoria do Patrimônio Genético, exercer as atribuições estabelecidas no artigo $7^{\circ}$, do Decreto 
$\mathrm{n}^{\circ}$ 3.945, de 28 de setembro de 2001, nos termos do artigo 22 do Decreto 6.101/2007. ${ }^{13}$ Entre elas, destaca-se emitir autorizações de acesso e de remessa de amostra de componente do patrimônio genético existente no território nacional, bem como autorização de acesso a conhecimento tradicional associado a instituição pública ou privada nacional, que exerça atividade de pesquisa e desenvolvimento nas áreas biológicas e afins e a universidade nacional, pública ou privada. Ressalte-se que tal autorização depende de anuência do Conselho de Gestão, pois a autorização é emitida em seu nome.

\subsection{Programas e Políticas Nacionais referentes à Conservação da Diversidade Biológica}

Após a CNUMAD, o Ministério de Meio Ambiente desenvolveu quatro eixos de ação para a conservação de biodiversidade, a saber: Programa Nacional de Conservação da Biodiversidade (PRONABIO), o Projeto de Conservação e Utilização Sustentável da Diversidade Biológica Brasileira (PROBIO), a Comissão Nacional da Biodiversidade (CONABIO) e a Política Nacional do Meio Ambiente. Elas serão tratadas a seguir.

\subsubsection{Programa Nacional de Conservação da Biodiversidade}

O Programa Nacional de Conservação da Biodiversidade foi criado pelo Decreto $\mathrm{n}^{\mathrm{o}}$ 1.354, de 29 de dezembro de 1994, com o objetivo principal de promover parceria entre o Poder Público e a sociedade civil na conservação da diversidade

\footnotetext{
${ }^{13}$ BRASIL, Decreto 6.101, art. 22: “Ao Departamento do Patrimônio Genético compete exercer as atribuições estabelecidas no art. 7o do Decreto no 3.945, de 28 de setembro de 2001.”
} 
biológica, utilização sustentável dos seus componentes e repartição justa e eqüitativa dos benefícios decorrentes dessa utilização. É o principal instrumento para a implementação da CDB no país. Tal decreto criou também sua Comissão Coordenadora, com a finalidade de coordenar, acompanhar e avaliar as ações do PRONABIO.

Esta Comissão Coordenadora era composta por dois representantes do setor empresarial, dois representantes do setor acadêmico, dois representantes das organizações não governamentais ambientalistas, seis representantes do Governo Federal, que englobava as áreas de Meio Ambiente, Ciência e Tecnologia, Agricultura, Saúde Planejamento e Relações Exteriores.

É importante ressaltar que este decreto foi promulgado ainda no ano de 1994, ou seja, no mesmo ano de ratificação da Convenção da Diversidade Biológica. Embora sucinto, este decreto cumpriu seu papel de estabelecer um programa nacional para a conservação da diversidade biológica.

As ações iniciais do PRONABIO concentraram-se no estabelecimento do modus operandi da Comissão Coordenadora, na sua interação com a sociedade civil e com outras instâncias governamentais. Além disso, concentrou seus esforços na definição de temas prioritários e na identificação de agentes financiadores que pudessem apoiar as iniciativas voltadas para a conservação e utilização da diversidade biológica brasileira (BRASIL, 1998, p.197).

Em virtude da assinatura do Decreto $n^{0}$ 4.339, de 22 de agosto de 2002, que instituiu os princípios e diretrizes para uma Política Nacional da Biodiversidade, o PRONABIO teve de ser modificado para atender a tais princípios e diretrizes. 
O PRONABIO continua a existir e é o programa pelo qual o Ministério do Meio Ambiente ainda coordena a implementação da Política Nacional do Meio Ambiente, mediante a promoção da parceria entre o poder público e a sociedade civil para o conhecimento, a conservação e o uso sustentável da diversidade biológica brasileira, bem como a repartição justa e eqüitativa dos benefícios derivados de sua utilização (BRASIL, 2002).

O novo decreto do PRONABIO, $n^{0} 4.703$, de 21 de maio de 2003, alterou o nome da antiga Comissão Coordenadora para Comissão Nacional da Biodiversidade (CONABIO) e definiu sua estrutura como matricial, com sete componentes temáticos, que são os mesmos da Política Nacional de Biodiversidade: conhecimento da biodiversidade; conservação da biodiversidade; uso sustentável dos componentes da biodiversidade; acompanhamento, avaliação, prevenção e mitigação dos impactos sobre a biodiversidade; acesso aos recursos genéticos e aos conhecimentos tradicionais da biodiversidade e repartição dos benefícios; educação e sensibilização pública; fortalecimento jurídico e institucional para a gestão da biodiversidade. Além disso, definiu sete componentes biogeográficos: Amazônia; Caatinga, Zona Costeira e Marinha; Mata Atlântica e Campos Sulinos; Cerrado e Pantanal.

Esse novo decreto, publicado nove anos após a criação do PRONABIO, ou seja, em 2003, apresenta uma evolução do conhecimento e das preocupações do governo federal com a conservação da diversidade biológica. Prova disto é a própria alteração da estrutura do decreto, que, em 2003, baseia-se inclusive na Política Nacional do Meio Ambiente que não existia em 1994. 


\subsubsection{Comissão Nacional da Biodiversidade}

Tendo em vista a importância desta Comissão, por se tratar de uma comissão deliberativa, este subitem será explicitado em maiores detalhes.

Com a criação, em 1994, do Programa Nacional da Diversidade Biológica (Decreto $n^{0}$ 1.354/94), para implementação da Convenção da Diversidade Biológica no Brasil, foi também estabelecida uma comissão coordenadora do Programa, com a finalidade de coordenar, acompanhar e avaliar as ações deste programa.

Com a publicação do Decreto $n^{\circ}$ 4.703, em 21 de maio de 2003, que alterou o PRONABIO a fim de adequá-lo aos princípios e diretrizes da nova Política Nacional do Meio Ambiente, esta antiga comissão passou a denominar-se Comissão Nacional da Biodiversidade.

A CONABIO é composta pelos representantes dos seguintes ministérios, de acordo com o artigo $7^{\circ}$ do Decreto $n^{\circ}$ 4.703/2004 e suas alterações. ${ }^{14}$ Ministério do Meio Ambiente, Ministério da Ciência e Tecnologia, Ministério da Agricultura, Pecuária e Abastecimento, Ministérios da Saúde, Ministérios das Relações Exteriores, Ministério do Planejamento, Orçamento e Gestão, Ministério do Desenvolvimento Agrário, Ministério da Integração Nacional.

Também compõem a CONABIO representantes das seguintes entidades: Secretaria Especial da Aqüicultura e Pesca da Presidência da República, Instituto Brasileiro do Meio Ambiente e dos Recursos Naturais Renováveis (IBAMA), Associação Brasileira das Entidades Estaduais do Meio Ambiente (ABEMA),

\footnotetext{
${ }^{14}$ http://www.planalto.gov.br/ccivil_03/decreto/2003/D4703.htm - acesso em 03 de agosto de 2007.
} 
Confederação Nacional de Trabalhadores na Agricultura (CONTAG), Movimento Nacional dos Pescadores (MONAPE), comunidade acadêmica, indicado pela Sociedade Brasileira para o Progresso da Ciência (SBPC), comunidade acadêmica, indicado pela Academia Brasileira de Ciências (ABC), organizações nãogovernamentais ambientalistas, indicado pelo Fórum de ONGs e Movimentos Sociais para o Meio Ambiente e para o Desenvolvimento, povos indígenas, indicado pela Coordenação das Organizações Indígenas da Amazônia (COIAB), setores empresariais vinculados à agricultura, indicado pela Confederação Nacional da Agricultura (CNA), setores empresariais vinculados à indústria, indicado pela Confederação Nacional da Indústria (CNI).

A competência da Comissão Nacional de Biodiversidade está estabelecida no artigo $6^{\circ}$, do Decreto $n^{\circ} 4.703$ de 21 de maio de 2003. Cabe à CONABIO, dentre outras funções:

“a) coordenar a elaboração da Política Nacional da Biodiversidade, com base nos princípios e diretrizes previstos no Decreto $n^{\circ} 4.339$, de 2002;

b) promover a implementação dos compromissos assumidos pelo Brasil junto à Convenção sobre Diversidade Biológica;

c) aprovar a metodologia para elaboração e o texto final dos relatórios nacionais para a Convenção sobre Diversidade Biológica;

d) propor medidas para o cumprimento, pelo Poder Público Federal, dos princípios e diretrizes para implementação da Política Nacional da Biodiversidade, instituídos pelo Decreto $n^{\circ} 4.339$, de 2002, estimulando a descentralização da execução das ações e assegurando a participação dos setores interessados;” 
No tocante à conservação da diversidade biológica no Brasil, cabe à Comissão, de acordo com item X, do artigo $6^{\circ}$, do Decreto 4.703/2003, identificar e propor áreas e ações prioritárias quanto à pesquisa, conservação, utilização sustentável, monitoramento, avaliação, prevenção e mitigação de impactos e áreas e ações prioritárias quanto à repartição de benefícios derivados da utilização da biodiversidade.

De acordo com a Portaria 153 de 23 de junho de 2004, que estabeleceu o regimento interno da CONABIO, a Comissão possui a seguinte estrutura: Plenário, Comissões Técnicas e Secretaria Executiva.

O Plenário é o órgão superior de deliberação da Comissão Nacional de Biodiversidade. A Secretaria-Executiva é composta por um Secretário-Executivo e por uma equipe técnica destinada a prestar apoio administrativo ao funcionamento da Comissão Nacional de Biodiversidade. Já as Câmaras Técnicas são instituídas pelo Plenário, mediante proposta do seu Presidente ou de qualquer membro, por meio de deliberação, que estabelecerá suas competências, composição, coordenação e tempo de duração, podendo ser permanentes ou temporárias, de acordo com a decisão do Plenário, no ato de sua criação.

O Plenário reúne-se, em caráter ordinário, uma vez a cada dois meses, conforme calendário aprovado mediante convocação escrita realizada pela Secretaria-Executiva, por ordem do Presidente da Comissão, devidamente acompanhada da pauta da reunião. Essas reuniões ocorrem nas instalações do Ministério do Meio Ambiente. 
O Plenário também pode reunir-se extraordinariamente mediante convocação escrita da Secretaria-Executiva por ordem do Presidente, ou da maioria absoluta de seus membros.

Por deliberação do Plenário da Comissão Nacional de Biodiversidade, as reuniões poderão ter caráter reservado, quando os temas a serem deliberados, exigirem esta condição. Mas, normalmente, poderão participar das reuniões ordinárias, a convite de seu Presidente, por solicitação de qualquer de seus membros em reunião anterior ou antecipadamente, até cinco dias da data designada para a reunião, representantes de outros órgãos e entidades da administração pública e/ou pessoas físicas e representantes de pessoas jurídicas que por sua experiência pessoal ou institucional, possam contribuir para os debates.

Os interessados em assistir as reuniões da Comissão Nacional de Biodiversidade que não tenham caráter reservado podem encaminhar pedido ao Presidente, obedecendo a antecedência mínima estabelecida no regimento interno. Todos os participantes das reuniões têm direito a voz, inclusive convidados.

Segundo o artigo 10 da citada Portaria, a Comissão deliberará por meio de resoluções, deliberações ou moções. As resoluções são atos administrativos que serão praticados quando se tratar de decisões para regulamentar a implementação da Política Nacional de Biodiversidade e da Convenção sobre Diversidade Biológica. As deliberações serão praticadas quando se tratar de decisões sobre editais, termos de referência, projetos e outras iniciativas referentes a matérias no âmbito das competências da Comissão Nacional de Biodiversidade e as moções, quando se tratar de manifestação sobre temas de biodiversidade que extrapolam suas competências. 
A CONABIO inova por ser um Conselho que reúne representantes de diversos setores do governo e de alguns setores da sociedade. Por vezes, no entanto, peca por um trabalho burocrático, distante da realidade de conflitos ambientais e que destoa das diversas decisões importantes que toma no âmbito dos projetos e subprojetos do PROBIO.

\subsubsection{Projeto de Conservação e Utilização Sustentável da Diversidade Biológica Brasileira}

Com a criação do PRONABIO, ainda em 1994, o governo brasileiro iniciou negociações com o GEF para receber recursos de doação para implementação do PRONABIO. O governo brasileiro e o Banco Internacional para a Reconstrução e Desenvolvimento (BIRD) assinaram, em 5 de junho de 1996, o Acordo de Doação TF 28309, de US\$ 10 milhões do GEF. Como contrapartida deste acordo, o Tesouro Nacional destinou o equivalente a US\$ 10 milhões à execução do Projeto de Conservação e Utilização Sustentável da Diversidade Biológica Brasileira (PROBIO). Este acordo teve vigência até 31 de dezembro de 2005 (MMA, 2002, p.73).

Desta forma, o PROBIO iniciou sua execução em 1997 com o orçamento de U\$ 20 milhões.

O PROBIO é coordenado pelo Ministério do Meio Ambiente em parceria com o Conselho Nacional de Desenvolvimento Científico e Tecnológico - CNPq, que atua como gestor administrativo, contratando os subprojetos e liberando recursos. É o mecanismo de auxílio técnico e financeiro na implementação do Programa Nacional da Diversidade Biológica, devendo ter todas as suas ações 
aprovadas pela Comissão Nacional de Biodiversidade, fórum responsável pela definição de diretrizes para implementação do PRONABIO e da Política Nacional de Biodiversidade.

O PROBIO identifica ações prioritárias, para apoiar a formulação de políticas públicas, estimulando a execução de subprojetos que promovam parcerias entre os setores público e privado e gerando e divulgando informações e conhecimentos no que tange à conservação e a utilização sustentável da diversidade brasileira.

A parceria com o CNPq foi oficializada, inicialmente, pela assinatura do convênio $n^{\circ}$ 149/96 firmado entre o MMA, Ministério de Ciência e Tecnologia (MCT) e CNPq e, posteriormente, pelo convênio $n^{\circ}$ 101/01 também entre as três instituições.

Com a implementação do PROBIO foi criado o Fundo Brasileiro para a Biodiversidade (FUNBIO), um fundo privado, que tem suas regras normatizadas em estatuto próprio ${ }^{15}$.

\footnotetext{
${ }^{15}$ O FUNBIO é uma associação civil sem fins lucrativos, criada em 28 de setembro de 1995, com o objetivo geral de complementar as ações governamentais para a conservação e o uso sustentável da diversidade biológica do país, em consonância com a Convenção sobre Diversidade Biológica, de âmbito mundial, e o Programa Nacional da Diversidade Biológica. Portanto, não é um órgão governamental e assim é regido por leis de direito privado. Para tanto, viabiliza iniciativas estratégicas de conservação e uso sustentável da biodiversidade que implementem o Programa Nacional da Diversidade Biológica, por meio de recursos arrecadados de fontes diversas. A atuação do FUNBIO é pautada pelas decisões do seu Conselho Deliberativo, formado por representantes dos setores empresarial, ambiental, acadêmico e governamental. As decisões de seu conselho são colocadas em prática pela Secretaria Executiva, que conta com 56 colaboradores. Até 2005 o FUNBIO implementou 62 projetos, com a publicação de cinco editais, todos de escala local e temáticas pontuais, em várias regiões do Brasil. Um total de US\$10 milhões foi repassado para cooperativas, associações comunitárias, universidades, empresas e organizações não governamentais. Os recursos que financiaram estes projetos locais são procedentes do fundo iniciado a partir de uma doação realizada pelo GEF no valor aproximado de US\$20 milhões. Essa doação, feita através de contrato com o Banco Mundial, teve como condicionante a constituição de um mecanismo de fomento. Para isso, o aporte de recursos do GEF vem sendo complementado pela captação de recursos.
} 
Logo que o acordo de doação entre o governo brasileiro e o GEF foi efetivado, sete subprojetos foram contratados pelo PROBIO:

1. Rede de Informação em Biodiversidade - Brasil;

2. Gerenciamento de Área Especial para a Região de Guaraqueçaba, Paraná;

3. Avaliação e Ações Prioritárias para Conservação da Biodiversidade no Bioma Cerrado e Pantanal;

4. Conservação e Recuperação da Mata Atlântica de Tabuleiros, com Base na Avaliação Funcional da Biodiversidade, em Linhares, Espírito Santo;

5. Recuperação e Manejo dos Ecossistemas Naturais de Brejos de Altitude de Pernambuco e Paraíba;

6. Conservação de Recursos Genéticos Vegetais;

7. Conservação e Recuperação da Biodiversidade em Matas de Galeria do Bioma Cerrado.

Nota-se aqui a ausência de um projeto específico de análise da Amazônia.

Entre 1998 e 2001, cinco subprojetos para avaliação de áreas e de ações prioritárias para a conservação da biodiversidade de áreas localizadas nos cinco biomas $^{16}$ existentes no Brasil foram executados (relativos ao edital lançado em

\footnotetext{
${ }^{16}$ Waldir Mantovani, no artigo A degradação dos Biomas Brasileiros, publicado no livro Patrimônio Ambiental Brasileiro, organizado por Wagner Costa Ribeiro, definiu bioma como "a mais ampla comunidade biótica reconhecida no nível geográfico, sendo definido como uma subdivisão biológica que reflete as características ecológicas e fisionômicas da vegetação. Corresponde, de um modo geral, às regiões climáticas, ainda que outros fatores ambientais possam ser importantes, como o solo e o fogo, sendo caracterizado em termos de todos dos organismos vivos e de suas interações com o
} 
1997), tendo como atividade primordial a identificação de prioridades para aplicação de recursos, levantamento de informações e disseminação de resultados. Os biomas foram agrupados da seguinte maneira:
a) Cerrado e Pantanal
b) Mata Atlântica e Campos Sulinos
c) Zona Costeira e Zona Marinha
d) Caatinga
e) Floresta Amazônica

Cada subprojeto estruturou-se na realização de uma oficina. Desta forma, foi analisada a riqueza biológica dos biomas, bem como as condicionantes socioeconômicas da região para, enfim, chegar-se à apresentação de uma estratégia geral para a conservação da biodiversidade de cada bioma. As áreas prioritárias foram identificadas em cada um dos biomas estudados.

Como critério para identificação de uma área prioritária, levou-se em consideração a importância biológica da área e a urgência das ações para sua conservação.

O principal resultado deste projeto foi a divulgação, no ano 2000, do Mapa das Áreas Prioritárias para a Conservação da Biodiversidade no Brasil. De maneira geral, essas áreas foram definidas nos seminários referidos acima e levaram em consideração as informações disponíveis sobre a diversidade biológica de cada sistema e pressão antrópica e na experiência dos pesquisadores participantes. 
Ao final, foram definidas 900 áreas como prioritárias, as quais foram reconhecidas por meio da publicação do Decreto $n^{0} 5.092$, de 21, de maio de 2004, e pela Portaria MMA nº 126, de 26 de maio de 2004, que determina a revisão periódica destas áreas, em prazo não superior a dez anos.

Durante o ano de 2006, o MMA realizou a revisão das áreas prioritárias para a conservação, uso sustentável e repartição de benefícios da biodiversidade, o que resultou na publicação da Portaria MMA nº. 09, de 23 de janeiro de 2007 e do livro "Áreas Prioritárias para Conservação, Uso Sustentável e Repartição de Benefícios da Biodiversidade Brasileira: Atualização - Portaria MMA nº 9, de 23 de janeiro de 2007. Ministério do Meio Ambiente, Secretaria de Biodiversidade e Florestas." Brasília: MMA, 2007. (Série Biodiversidade, 31).

O mapa de áreas prioritárias, revisto em 2006, encontra-se na Figura 2. 
Figura 2 - Mapa de Áreas Prioritárias para Conservação da Biodiversidade no Brasil

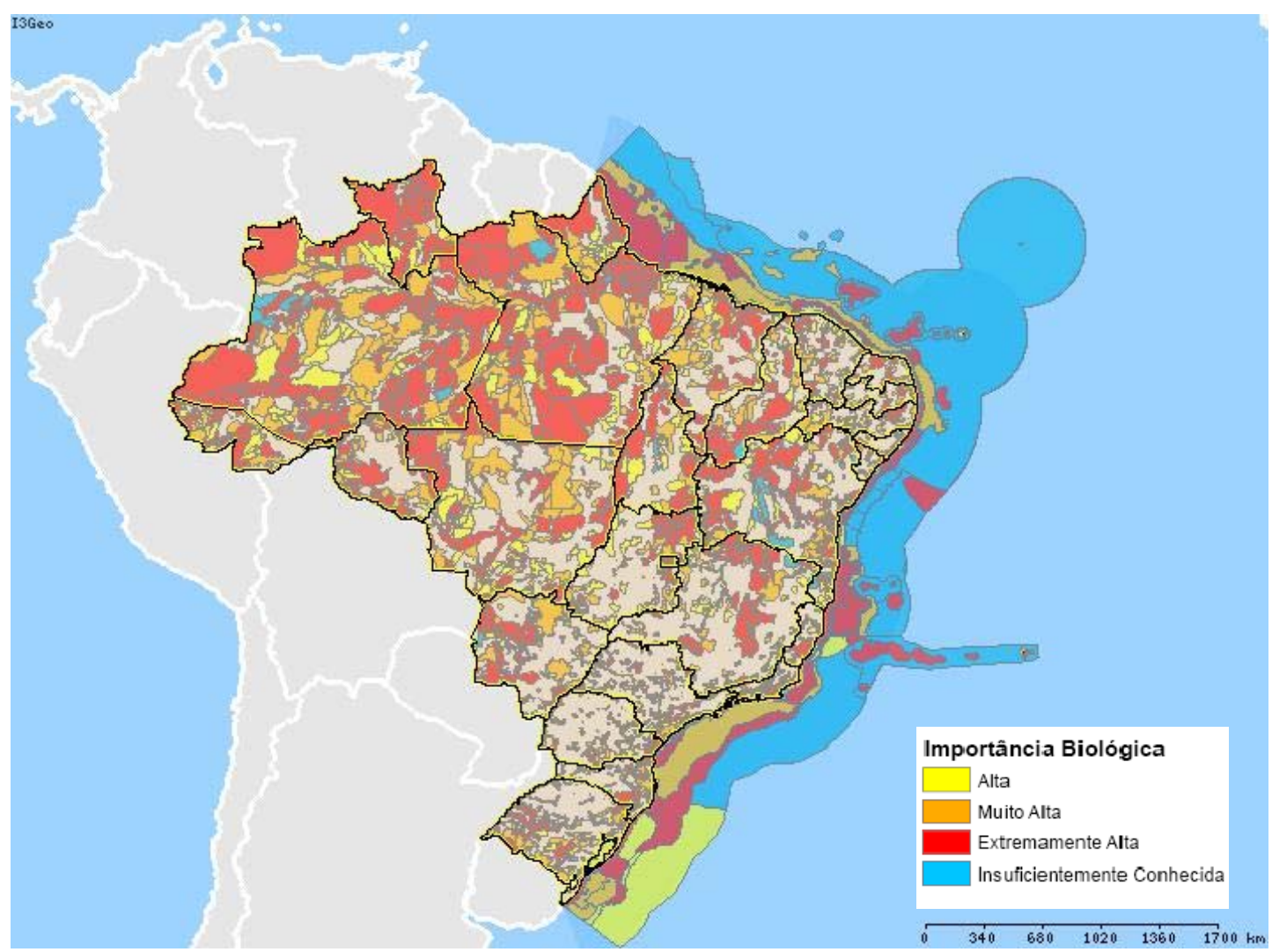

Fonte: Adapt. MMA, 2007. http://www.mma.gov.br/index.php?ido=conteudo.monta\&idEstrutura=72 \&idConteudo=5454 - acesso em 20 de dezembro de 2007.

Ainda no ano de 1997, um novo edital foi lançado, desta feita para seleção de projetos voltados para a conservação e manejo sustentável de ecossistemas naturais em processo de fragmentação e restauração de ecossistemas fragmentados. Quinze subprojetos demonstrativos nessa área foram aprovados e realizados, a maioria deles tendo três anos de duração.

Segundo dados constantes do Relatório de Atividade PROBIO, 2002-2004, durante quase nove anos, ou seja, até o início de 2004, o PROBIO já havia apoiado 149 subprojetos, com uma alocação de recursos na ordem de $\mathrm{R} \$ 37.296 .305,00$ (MMA, 2004). 
O PROBIO atua por meio de demanda induzida. Publica editais ou cartas consulta. Em seguida, são apresentadas propostas às Câmaras Técnicas Temporárias, as quais, após análise dos projetos, indicam as selecionadas à Comissão Nacional de Biodiversidade (CONABIO) que as aprovam ou não.

O PROBIO, por meio da aprovação de seus subprojetos, é o responsável direto pela implementação da Política Nacional do Meio Ambiente.

\subsubsection{Política Nacional de Conservação da Diversidade Biológica}

Com a finalidade de formular a proposta da Política Nacional de Biodiversidade (PNB), ou seja, pensando na elaboração de um plano gestor que visasse à mitigação de conflitos atinentes à conservação da biodiversidade, o Ministério do Meio Ambiente estabeleceu um processo de consulta no período de 2000 a 2001. Participaram desta consulta setores envolvidos com o tema, como: governo federal, organizações não-governamentais (ONGs), comunidades acadêmicas, indígenas e locais e empresários.

Procurava-se, com esta consulta, estabelecer pontos comuns, interesses comuns que interligados, fossem capazes de construir a base para um plano nacional de conservação da diversidade biológica.

No mesmo sentido, foram realizados estudos básicos no período 1998-2001, que enfocaram o tema da conservação da diversidade biológica com base em diferentes aspectos, como o nível de adequação da legislação brasileira à Convenção sobre Diversidade Biológica, a síntese do atual conhecimento da biodiversidade brasileira, a análise comparativa de estratégias nacionais de biodiversidade de 46 
países e a síntese de registros sobre o conhecimento tradicional associado à biodiversidade.

Paralelamente à consulta nacional, o Ministério do Meio Ambiente promoveu cinco avaliações por biomas, no período 1998-2000, identificando 900 áreas e ações prioritárias para a conservação da biodiversidade na Amazônia, Cerrado e Pantanal, Caatinga, Mata Atlântica e Campos Sulinos, Zona Costeira e Marinha, conforme relatado no subitem referente ao PROBIO.

Baseando-se nos estudos básicos, nas avaliações por biomas e nos resultados da consulta nacional, o MMA ultimou, em março de 2002, um documento preliminar da PNB. Em seguida, nos meses de abril e maio de 2002, realizou quatro reuniões em diferentes capitais com o objetivo de analisar o Primeiro Rascunho e definir a proposta final da PNB. Esta incluiu os seguintes temas: conhecimento da biodiversidade, conservação, uso sustentável, repartição de benefícios, fortalecimento de capacidades científicas e tecnológicas, e educação e consciência pública.

A proposta de política foi discutida no Conselho Nacional do Meio Ambiente. Com isso, foi finalizado o processo de consulta para elaboração da Proposta de Política de Biodiversidade em agosto de 2002, o que culminou com a publicação do Decreto $n^{\circ} 4.339$, de 22 de agosto de 2002, que instituiu os princípios e diretrizes para a implementação da Política Nacional de Biodiversidade.

Desta forma, o Programa Nacional de Biodiversidade, instituído pelo Decreto $\mathrm{n}^{\circ}$ 1.354, de 29 de dezembro de 1994, com o objetivo de coordenar a implementação de compromissos da CDB no país, foi modificado, sendo agora o 
Programa Nacional de Biodiversidade o documento legal base que fundamenta e orienta a implementação da CDB no Brasil.

As diretrizes da Política Nacional da Biodiversidade estão elencadas no item quatro do Anexo em nove incisos. Afora o inciso I (que estabelece a cooperação com outras nações, no que respeita a áreas além da jurisdição nacional, em particular nas áreas de fronteira, na Antártida, no alto-mar e nos grandes fundos marinhos, em relação a espécies migratórias e em outros assuntos de mútuo interesse, para a conservação e a utilização sustentável da diversidade biológica), não há qualquer inovação nos demais incisos. Pelo contrário, observam-se frases extremamente óbvias e inócuas, que tornam o texto extenso e burocrático. Exemplo disto são os incisos II e III deste mesmo item quatro:

"II - o esforço nacional de conservação e a utilização sustentável da diversidade biológica deve ser integrado (sic!) em planos, programas e políticas setoriais ou intersetoriais pertinentes de forma complementar e harmônica;

III - investimentos substanciais são necessários para conservar a diversidade biológica, dos quais resultarão, conseqüentemente, benefícios ambientais, econômicos e sociais;”

O objetivo da Política Nacional da Biodiversidade é dado pelo item cinco e não poderia ser outro além da promoção, de forma integrada, da conservação da biodiversidade e da utilização sustentável de seus componentes, com a repartição justa e eqüitativa dos benefícios derivados da utilização dos recursos genéticos, de componentes do patrimônio genético e dos conhecimentos tradicionais associados a esses recursos. 
Nos itens seis, sete oito e nove, a PNB traz uma divisão de sete componentes, que são os eixos temáticos que orientarão a implementação desta Política. Dentro de cada um deles, estão especificadas as diretrizes gerais que devem ser consideradas caso o componente seja adotado para determinado bioma considerado. Além disso, diretrizes específicas por bioma poderão ser estabelecidas nos Planos de Ação, quando da implementação da Política. Os componentes são:

- $\quad$ Componente 1: Conhecimento da Biodiversidade

- $\quad$ Componente 2: Conservação da Biodiversidade

- $\quad$ Componente 3: Utilização Sustentável dos Componentes da

Biodiversidade

- $\quad$ Componente 4: Monitoramento, Avaliação, Prevenção e Mitigação de impactos sobre a Diversidade

- $\quad$ Componente 5: Acesso aos Recursos Genéticos e aos Conhecimentos

Tradicionais Associados e Repartição de Benefícios

- $\quad$ Componente 6: Educação, Sensibilização Pública, Informação e

Divulgação sobre Diversidade

- Componente 7: Fortalecimento Jurídico e Institucional para a Gestão da Biodiversidade

Após uma pequena definição de cada componente, traz nos itens subseqüentes, os objetivos gerais, as diretrizes e os objetivos específicos de cada uma das diretrizes, para cada um dos componentes, explicitando mecanismos de gestão para conservação da biodiversidade. É, sem dúvida, a parte melhor elaborada do texto legal que, se bem aplicada, servirá como um bom norteador aos que, de alguma 
forma, se preocupam com a conservação ambiental. Mas, apesar de ser a melhor parte do texto, ainda traz redundâncias que poderiam ser enxugadas, como, por exemplo, os subitens 11.2.1 e 11.2.2, que são objetivos específicos do Componente 2, Conservação da Biodiversidade, que afirmam:

“11.2.1. Apoiar e promover a consolidação e a expansão do Sistema Nacional de Unidades de Conservação da Natureza - SNUC, com atenção particular para as unidades de proteção integral, garantindo a representatividade dos ecossistemas e das ecorregiões e a oferta sustentável dos serviços ambientais e a integridade dos ecossistemas.

11.2.2. Promover e apoiar o desenvolvimento de mecanismos técnicos e econômicos para a implementação efetiva de Unidades de Conservação (....)"

Estas redundâncias, conforme dito acima, tornam o texto longo, contribuindo para uma legislação extensa e de difícil consulta, chegando a ser burocrática. As redundâncias se explicam pelo fato de que estas afirmativas se encontram em outros textos legais como o Decreto n ${ }^{0} 1.354 / 1994$, a Lei 9.985/00,

Por fim, o Decreto traz a última parte denominada arcabouço jurídico institucional em que “delega” ao Ministério do Meio Ambiente as funções de execução da Política Nacional da Biodiversidade que já seriam suas pelo Decreto de criação do Ministério. Portanto, trata-se de mais uma redundância.

Não se quer com estas críticas tirar o mérito dos fóruns criados para discussão da PNB, mas o que se pretende com os pontos que foram elencados é indicar que, um texto legal inequívoco e enxuto é um instrumento facilitador para boas ações de gestão pública. 


\subsection{Relatórios Nacionais para a Convenção da Diversidade Biológica no} Brasil

A elaboração de Relatórios periódicos contendo informações acerca da implementação da Convenção sobre Diversidade Biológica (CDB) é compromisso de seus membros, previsto no Artigo 26 daquela convenção. Por outro lado, esses relatórios funcionam como importantes subsídios à formulação de políticas públicas ambientais, pois possibilitam a avaliação das ações empreendidas no país voltadas à conservação e ao uso sustentável de seu patrimônio natural.

O primeiro Relatório Nacional para a Convenção sobre a Diversidade Biológica no Brasil foi publicado em 1998 e era subdividido em seis capítulos assim denominados: (i) Apresentação da Diversidade Biológica Brasileira, (ii) Situação da Diversidade Biológica Brasileira, (iii) Capacidade Institucional, (iv) Legislação, (v) Políticas e (vi) Programas, implementando o artigo $6^{\circ}$ da Convenção sobre Diversidade Biológica, Contribuição Brasileira para o Avanço da Convenção sobre a Diversidade Biológica no Âmbito Mundial e Perspectivas (MMA, 1998).

Desta publicação cabe ressaltar apenas alguns pontos referentes às perspectivas apontadas no relatório, uma vez que os principais dados fornecidos pelo documento referentes aos assuntos abordados nesta dissertação foram inseridos nos respectivos subitens.

Primeiramente, é importante lembrar que no ano de divulgação do relatório, ou seja, 1998, ainda não havia sido publicada a lei sobre acesso a recursos genéticos. Tramitava no Senado o então Projeto de Lei nº 306/95 e, desta forma, sua aprovação 
foi colocada como um dos pontos principais das Perspectivas, abordadas no Capítulo VI do relatório.

Por outro lado, o Governo Federal prometia, nesta publicação, a aplicação de US\$1,5 bilhão no Sistema de Vigilância da Amazônia (SIVAM). Tratava-se de um novo sistema de monitoramento de toda a região Amazônica. Os recursos, segundo o mesmo relatório, seriam aplicados em aquisição de dados (US\$625 milhões), tratamento e visualização (US\$151 milhões), telecomunicações (US\$104 milhões), logística (US\$228 milhões), integração e serviços complementares (US\$170 milhões), auxílio à navegação aérea (US\$7 milhões) e obras civis (US\$150 milhões). Vale ressaltar a importância deste sistema que existe até hoje, sendo, certamente, um dos instrumentos responsáveis pela queda do índice do desmatamento da Amazônia anunciado pelo Ministério do Meio Ambiente em $2007^{17}$.

No tocante à preservação in situ, objeto deste trabalho, menciona que o então Presidente da República, Sr. Fernando Henrique Cardoso, assumiu o compromisso, durante viagem realizada ao Reino Unido, no final de 1997, de preservação integral de no mínimo 10\% da floresta tropical brasileira, até o ano de 2000. Esta ainda é a meta do governo atual, em 2007.

E, por fim, lança a idéia do projeto dos corredores ecológicos da Floresta Amazônica e Mata Atlântica (Projeto Parques e Reservas) para conservação de 25\% da floresta tropical úmida e 75\% das espécies animais e plantas silvestres presentes

${ }^{17}$ GRUPO PERMANENTE DE TRABALHO INTERMINISTERIAL SOBRE DESMATAMENTO NA AMAZÔNIA. Instituído por Decreto de 3 de julho de 2003. Reúne 13 ministérios coordenados pela Casa Civil da Presidência da República. Disponível em http://www.mma.gov.br/. Acesso em 30 de dezembro de 2007. 
nestes biomas. Promete, ainda, para o final do ano de 1999, a elaboração da Estratégia Nacional da Diversidade Biológica.

O Segundo Relatório Nacional para a Convenção sobre Diversidade Biológica: Brasil foi publicado no ano de 2004 e procurou apresentar o grau de implementação da Convenção sobre Diversidade Biológica até dezembro de 2002 (MMA, 2004b). É importante frisar que, em janeiro de 2003, o Sr. Luis Inácio Lula da Silva tomou posse como Presidente da República, sendo que este relatório foi elaborado, portanto, pela nova equipe de governo chefiada pela Ministra Marina Silva, mas relatava os avanços obtidos na antiga gestão do então Presidente Sr. Fernando Henrique Cardoso.

Com o objetivo de padronizar os relatórios dos países signatários da Convenção da Diversidade Biológica, o Secretariado daquela convenção estabeleceu um Guia para Relatórios Nacionais. Segundo este Guia, que apresenta perguntas sobre o grau de implementação de cada um dos artigos da Convenção, os relatórios nacionais deveriam discriminar as iniciativas, programas e ações de abrangência nacionais e regionais, que mantinham interface com os artigos da Convenção. Esses relatórios deveriam, ainda, demonstrar os avanços e empecilhos à implementação da Convenção.

Para a elaboração deste Segundo Relatório e tendo em vista as dificuldades de elaboração de um trabalho desta envergadura, o Ministério do Meio Ambiente elaborou uma metodologia de elaboração que consistia em quatro etapas:

a) elaboração, pela equipe do Ministério, de uma proposta prévia para o relatório; 
b) validação e complementação desta proposta pelos gerentes dos planos plurianuais do governo (PPAs), que mantinham interface com a biodiversidade em reunião que realizou-se nos dias 7 e 8 de novembro de 2002.

Foram selecionados 50 programas do Plano Plurianual do Governo Federal, que mantinham interfaces com a Convenção. Nos dias 7 e 8 de novembro de 2002 realizou-se a reunião com os representantes desses programas que responderam e comentaram a minuta do Guia para Relatórios Nacionais;

c) validação e complementação dessa proposta por outros setores da sociedade que, de alguma forma, participam da gestão da biodiversidade no Brasil, em reunião que realizou-se nos dias 26 e 27 de novembro de 2002 em Brasília.

Foram selecionadas 65 ONGs, consultadas por meio de ofício, das quais 19 foram convidadas a analisar e criticar o questionário, sendo que nos 26 e 27 de novembro responderam ao questionário. Foi solicitado, também, às Secretarias Estaduais de Meio Ambiente dos 26 Estados brasileiros, que sintetizassem e enviassem ao Ministério as principais iniciativas estaduais para o cumprimento dos artigos da Convenção. Sete Estados responderam à solicitação.

No primeiro capítulo estão contidas as questões e respostas do questionário do Guia de Relatórios Nacionais, estabelecido pelas partes da Convenção, conforme Decisão V/19 como roteiro para elaboração dos relatórios nacionais. O Sr. 
Secretário de Biodiversidade e Florestas, João Capobianco, esclarece na Apresentação do Relatório ${ }^{18}$ :

"No Guia para Relatórios Nacionais há um conjunto de perguntas para cada artigo da $C D B$, sendo que existem duas perguntas que se repetem para todos os artigos, referentes ao grau de prioridade dado pelo país à implementação daquele artigo e à disponibilidade de recursos para implementar as ações necessárias. Para responder a essas duas questões, primeiramente foi feito um levantamento das iniciativas realizadas no país que atendem ao artigo da $C D B$ em questão. A partir desse levantamento, foi possível avaliar o grau de prioridade dado pelo país e a disponibilidade de recursos para implementação daquele artigo. O MMA estabeleceu, então, critérios para responder a essas perguntas. A partir do levantamento das iniciativas nacionais relacionadas com aquele artigo, avaliou-se se o referido artigo estava contemplado em: legislação, política, programa e linha de fomento. Ao artigo contemplado em três ou quatro casos acima, considerou-se a prioridade dada como ALTA; se estivesse contemplado em um ou dois casos acima, a prioridade foi considerada MÉDIA; e, se não estivesse contemplado em nenhum dos casos acima, BAIXA. Para avaliar a disponibilidade de recursos, foram considerados: recursos financeiros, recursos humanos, recursos institucionais e instrumentos legais e econômicos. Se o Brasil possuísse quatro dos elementos citados acima para um determinado artigo da $C D B$, a disponibilidade de recursos foi considerada BOA; se possuísse três elementos, a disponibilidade de recursos foi considerada ADEQUADA; se possuísse dois dos elementos, LIMITANTE; e, finalmente, se possuísse um ou nenhum, SEVERAMENTE LIMITANTE."(MMA, 2004b, p.18)

Como se observa no trecho transcrito acima, o simples fato de um tema ser mencionado em uma legislação, política, programa ou linha de governo, já o faz ser considerado como tema de alta prioridade. Certo é que algum critério deve ser estabelecido, para que comparações e análises possam ser feitas, inclusive entre os 
países signatários da Convenção. Mas, do trecho transcrito, podemos concluir que faltou um preciosismo maior para conclusões mais específicas.

Deste relatório é importante frisar alguns marcos das políticas públicas adotadas como as publicações, no ano de 2003, da Lista de Espécies da Fauna Brasileira Ameaçados de Extinção (BRASIL, 2006) - que não era atualizada desde 1989 e no ano de 2004, da Lista Nacional de Invertebrados Aquáticos e Peixes Ameaçados de Extinção (BRASIL, 2004).

As demais informações importantes ressaltadas no Prefácio da publicação pela Sra. Ministra de Estado, Marina Silva, referem-se à alteração da composição da Comissão Nacional da Biodiversidade, tratado no subitem 3.3 deste Capítulo e também a publicação da Portaria no 126, de 2004 referente às áreas prioritárias, tratada no subitem 3.1 deste Capítulo.

O Terceiro Relatório Nacional para a Convenção da Diversidade Biológica: Brasil, apresenta um resumo das principais iniciativas que refletem o grau de implementação da CDB no país, até o ano de 2005 (MMA, 2006). Assim como o Segundo Relatório, foi elaborado com base no Guia para Relatórios Nacionais (Guidelines for National Reports), estabelecido pelas Partes da Convenção (Decisões V/19, VI/25 e VII/25).

Este Guia previa a elaboração de um Relatório composto por duas partes: a primeira deveria indicar as iniciativas realizadas no país que contribuíram ou contribuem para a implementação dos artigos da Convenção; a outra parte deveria definir metas nacionais de redução da perda da biodiversidade, correlatas às metas 
globais definidas no Plano Estratégico da CDB para 2010 e na Estratégia Global para Conservação de Plantas.

Ocorre que o Brasil, até a realização do relatório, não havia estabelecido tais metas, motivo pelo qual optou pela elaboração apenas da parte referente ao relato da implementação dos artigos da CDB no país. Quanto à forma de elaboração deste Relatório, esta seguiu a mesma do Segundo Relatório, descrita acima.

No momento de consolidação de dados, uma minuta do documento foi elaborada e colocada em discussão em duas reuniões de consulta e de validação do documento, realizadas nos dias 11, 12, 18 e 19 de abril de 2005, em Brasília. O documento final foi submetido à discussão e aprovação pela CONABIO (Deliberação nº 28, em 04 de maio de 2005).

\subsection{Da implementação do artigo 8, letras "a" e "b", da CDB}

As letras “a” e "b” do artigo $8^{\circ}$ da CDB tratam da criação e implementação de um sistema nacional de áreas protegidas nos países signatários deste acordo.

Neste subitem serão abordadas as principais políticas públicas implementadas pelo Brasil para a conservação da diversidade biológica que se referem especificamente às áreas protegidas. São elas o Programa Áreas Protegidas da Amazônia (ARPA) e o Plano Nacional Estratégico de Áreas Protegidas.

\subsubsection{Programa Áreas Protegidas da Amazônia}

Instituído em 08 de agosto de 2002, pelo decreto federal no 4.326, o ARPA tem como meta estabelecer um regime de proteção ambiental para conservação de 50 
milhões de hectares no bioma Amazônia em um prazo de dez anos, atingindo os seguintes objetivos:

- Criar e consolidar 28,5 milhões de hectares de novas áreas de proteção integral (parques nacionais, reservas biológicas e estações ecológicas).

- Criar nove milhões de hectares de áreas protegidas de uso sustentável comunitário (reservas extrativistas e reservas de desenvolvimento sustentável).

- Estabelecer um fundo fiduciário $^{19}$ de capitalização permanente (endowment), cujos rendimentos serão usados para financiar em perpetuidade custos de manutenção e proteção das Unidades de Conservação (UCs) implementadas pelo ARPA.

- Implementar um sistema de monitoramento da biodiversidade na Amazônia.

Estão envolvidas neste projeto, instituições governamentais e não governamentais. As instituições governamentais são: Ministério do Meio Ambiente, IBAMA, Organizações Estaduais de Meio Ambiente (OEMAs), Fundação Nacional do Índio - FUNAI, Instituto Nacional de Colonização e Reforma Agrária (INCRA).

Coordenado pelo Ministério do Meio Ambiente e pelo IBAMA, que promovem o planejamento de metas e monitoram e supervisionam a sua execução,

\footnotetext{
${ }^{19}$ Fundo fiduciário, segundo o Relatório de Atividades do ARPA, Agosto de 2006 a Agosto de 2007, é um fundo permanente que recebe um investimento de capital e é administrado por meio de investimentos em ativos de baixo risco. Apenas os seus rendimentos são sacados, periodicamente, para atender os objetivos do Projeto. Disponível em http://www.mma.gov.br/estruturas/sbf_dap_arpa/_arquivos/Relatorioanualfinal.pdf - acesso em 18 de novembro de 2007.
} 
tem a execução financeira feita pelo Fundo Brasileiro para a Biodiversidade. A execução técnica, a partir dos meios disponibilizados pelo FUNBIO, é feita pelos órgãos gestores de Unidades de Conservação nas esferas federal e estadual. Outras organizações doam recursos financeiros e supervisionam a execução do ARPA: Fundo para o Meio Ambiente Global, por meio do Banco Mundial; KfW, Banco de Desenvolvimento Alemão e WWF-Brasil (organização não-governamental voltada à conservação ambiental).

As seguintes Unidades de Conservação, indicadas na Figura 3, são apoiadas pelo ARPA: 
Figura 3 - Unidades de Conservação Apoiadas pelo Programa Áreas Protegidas da Amazônia

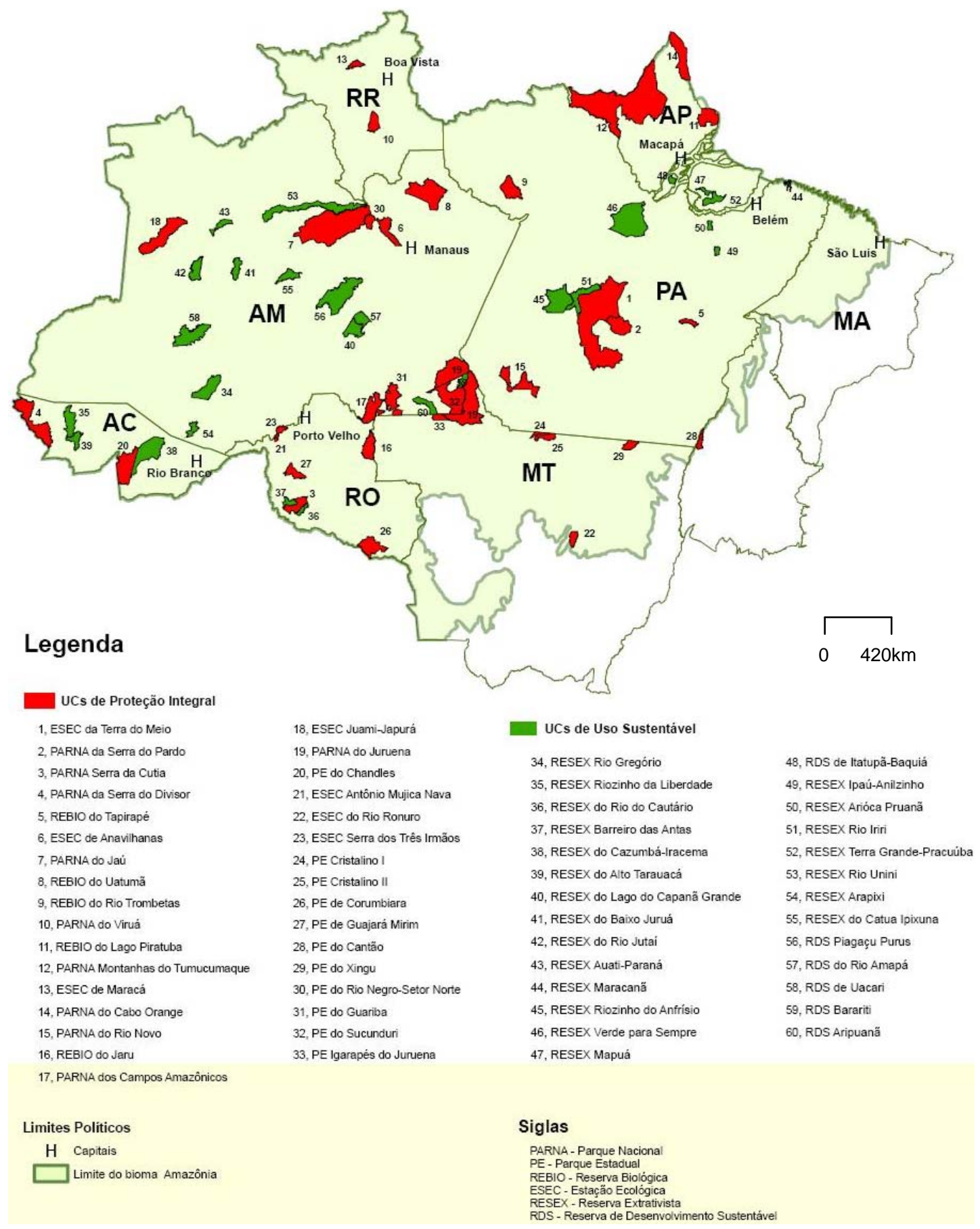

Fonte: Unidade Coordenadora do Programa ARPA, 2007. http://www.mma.gov.br/index.php?ido= conteudo.monta\&idEstrutura=97\&idConteudo=6403 - acesso em 15 de dezembro de 2007 
O ARPA prevê que suas metas sejam alcançadas ao longo de dez anos, em três fases distintas e complementares de implementação. Após a conclusão do Programa, a manutenção das áreas deverá ser viabilizada por mecanismos de sustentabilidade financeira e por um fundo de longo prazo, o Fundo de Áreas Protegidas - FAP (FUNBIO, 2005).

Ele está dividido em três fases:

Fase 1 (2003 - 2006)

- Criação de novas UCs:

o 9 milhões de hectares de UCs de proteção integral.

o 9 milhões de hectares de UCs de uso sustentável.

- Consolidação de UCs de proteção integral já existentes: 7,3 milhões hectares.

- Fundo de Áreas Protegidas (FAP): capitalização de até US\$ 29 milhões em quatro anos.

- Monitoramento da biodiversidade nas UCs.

Fase 2 (2007 - 2009)

- Criação de 18 milhões de hectares de novas UCs proteção integral.

- Consolidação do restante das UCs de proteção integral já existentes.

- Consolidação das UCs de proteção integral criadas no âmbito do Projeto.

- Continuação da capitalização do FAP. 
Fase 3 (2010 - 2013)

- Continuação da consolidação das UCs de proteção integral.

- Capitalização do Fundo de Áreas Protegidas para um total US\$ 240 milhões.

Podem ser beneficiadas pelo programa tanto Unidades de Conservação de proteção integral, quanto de uso sustentável, mas, para ser beneficiada, deve passar por um processo de seleção fundamentado em três critérios: ausência de conflitos com terras indígenas, situação fundiária favorável e viabilidade para a consolidação da área.

O Comitê do Programa (CP) ARPA é a instância máxima de decisão sobre os rumos da iniciativa. O CP é composto por doze membros, seis representantes do governo e seis representantes da sociedade civil. O CP tem a responsabilidade de definir prioridades e diretrizes de ação, de analisar e aprovar os Planos Operativos Anuais das Unidades de Conservação e das instituições executoras.

O Programa foi organizado, ainda, em instâncias administrativas, consultivas e deliberativas, a saber: Coordenação Geral do Programa, Comitê do Programa, Painel Científico de Acompanhamento, Comitê Científico de Acompanhamento, Fórum Técnico e Unidade de Coordenação do Programa.

No ano de 2005, o Programa criou a conta vinculada, mecanismo de repasse e uso de recursos pelos gestores das áreas protegidas. Trata-se de uma espécie de conta conjunta do FUNBIO com a UC, destinada à compra e pagamento de serviços de pequeno porte. Ao utilizá-la, cada responsável pela unidade assina um termo de 
responsabilidade. Até o final de 2006 foram desembolsados R\$ 6,1 milhões para a iniciativa, por meio de 56 contas em funcionamento.

Desde julho de 2000, o Conselho Deliberativo manifestou intenção em participar do ARPA. Porém, foram necessários quase dois anos para que se definissem as condições dessa participação. Em março de 2002, o governo federal nomeou oficialmente o Fundo como recebedor de uma doação de US\$ 30 milhões oriundos do GEF (sob supervisão do Banco Mundial) e iniciaram-se as negociações com o WWF-Brasil e o KfW para oficializar o repasse de recursos. O contrato com o WWF-Brasil, no valor de US\$ 11,5 milhões, foi assinado em 23 de abril de 2003. O acordo com o banco alemão, que envolve o repasse de $€$ 17,6 milhões, foi firmado em 12 de novembro de 2004.

\subsubsection{O Plano Nacional de Áreas Protegidas}

Com a criação do grupo de trabalho de áreas protegidas no âmbito da Convenção da Diversidade Biológica, conforme explanação feita no Capítulo 3 deste trabalho, coube ao Brasil ajustar o Programa de Trabalho sobre Áreas Protegidas da CDB às suas especificidades, prioridades e capacidades.

Com isto, surgiu o Plano Nacional de Áreas Protegidas, que é um instrumento jurídico norteador de planejamento e gestão, que define princípios, diretrizes, objetivos e estratégias para o estabelecimento, até 2015. Trata-se de um sistema abrangente de áreas protegidas, ecologicamente representativo e efetivamente manejado que também visa à promoção de acesso e repartição justa e eqüitativa dos custos e benefícios advindos da conservação da natureza. 
Teve como ação inicial um Protocolo de Intenções firmado em 2004 entre o Ministério do Meio Ambiente e um conjunto de organizações não-governamentais e movimentos sociais de âmbito nacional e internacional, com o objetivo de conjugar as capacidades técnicas, científicas, financeiras e políticas em prol da formulação e implementação de um Plano Nacional de Áreas Protegidas.

Com a finalidade de formulação de propostas de um Plano, criou-se um Fórum Nacional de Áreas Protegidas, que serviu como canal de diálogo aberto à sociedade e à instituição de um grupo de trabalho ministerial (GT). No âmbito deste grupo de trabalho, foi constituído um grupo técnico especializado com a finalidade de sugerir os objetivos e estratégias para as áreas protegidas situadas em ambientes costeiros e marinhos, com base nas especificidades desses ecossistemas.

A proposta do Plano, elaborada pelo Grupo de Trabalho, foi disponibilizada para consulta pública em janeiro de 2006 no Fórum Nacional de Áreas Protegidas. A proposta, após incorporar as sugestões da etapa de consulta, foi avaliada no âmbito das Câmaras Técnicas de Unidades de Conservação e demais Áreas Protegidas e da de Assuntos Jurídicos do Conselho Nacional do Meio Ambiente.

O CONAMA, em sua 47ª Reunião Extraordinária, realizada em 16 de março de 2006, por meio de decreto presidencial, recomendou a instituição do Plano Nacional de Áreas Protegidas, para implementação de um sistema de áreas protegidas que fosse realmente abrangente, ecologicamente representativo, efetivamente manejado e integrado a paisagens terrestres e marinhas mais amplas, até 2015. Recomendou também a criação de uma comissão executiva, com a participação e colaboração de representantes do governo federal, dos governos 
distrital, estaduais e municipais, de povos indígenas, de comunidades quilombolas e de extrativistas, do setor empresarial e da sociedade civil. Todos com a atribuição de definir metas e mecanismos de implementação do Plano, sempre ouvidos o Conselho Nacional do Meio Ambiente, a Secretaria Especial de Políticas de Promoção da Igualdade Racial (SEPPIR) e a Fundação Nacional do Índio.

Desta forma, em 13 de abril de 2006, foi publicado o decreto federal ${ }^{0} 5.758$, que instituiu o Plano Estratégico Nacional das Áreas Protegidas (PNAP).

O PNAP, assim como a Política Nacional da Biodiversidade já apresentada, institui princípios, diretrizes e objetivos nos primeiros itens do Anexo do Decreto. Depois, detalha os objetivos e as ações para o Sistema Nacional de Unidades de Conservação (SNUC), para as terras indígenas e para as terras ocupadas por remanescentes das comunidades dos quilombos e os orienta sob a forma de quatro eixos temáticos interligados e inter-relacionados, da seguinte forma:

1. Eixo Temático: Planejamento, Fortalecimento e Gestão

2. Eixo Temático: Governança, Participação, Eqüidade e Repartição de Custos e Benefícios

3. Eixo Temático: Capacidade Institucional

4. Eixo Temático: Avaliação e Monitoramento

Então, estabelece, dentro de cada eixo temático, os objetivos gerais. E, em cada objetivo geral, os objetivos específicos e as estratégias para alcançá-los. Por exemplo, o Eixo Temático Governança, Participação, Equidade e Repartição de Custos e Benefícios possui os seguintes objetivos gerais: 
"5.1. OBJETIVO GERAL: estabelecer um ambiente político, institucional, administrativo e socioeconômico favorável para implementação do SNUC nas três esferas de governo,

5.2. OBJETIVO GERAL: desenvolver a capacidade de planejar, estabelecer e administrar Unidades de Conservação,

5.3. OBJETIVO GERAL: desenvolver, aplicar e transferir tecnologias para o SNUC,

5.4. OBJETIVO GERAL: garantir a sustentabilidade econômica das Unidades de Conservação e do SNUC,

5.5. OBJETIVO GERAL: fortalecer a comunicação, a educação e a sensibilização pública para a participação e controle social sobre o SNUC.”

Dentro de cada um destes objetivos são elencados os objetivos específicos e suas estratégias para alcançá-los.

Este processo é realizado primeiramente para o SNUC na parte intitulada “Dos Objetivos Gerais, Objetivos Específicos e Estratégias para o SNUC”. Já a última parte do Decreto intitulada "Das Estratégias Nacionais para as Áreas com Reconhecimento Internacional", apresenta como objetivo geral apenas implementar convenções, tratados e programas intergovernamentais, relacionados às áreas naturais protegidas, dos quais o Brasil é parte e apresenta seus objetivos específicos e estratégias em separado.

A publicação do Ministério do Meio Ambiente sobre Áreas Protegidas de 2007, denominada Informe Nacional sobre Áreas Protegidas, destaca a inovação do PNAP também porque: 
"Coerentemente com a decisão VII/28, o PNAP reconhece a importância das terras indígenas e das terras de comunidades remanescentes de quilombos como parte da política de conservação da biodiversidade brasileira. Ao integrá-las ao esforço de planejamento da paisagem, ao lado das Unidades de Conservação estabelecidas pela Lei no 9.985/2000, o PNAP amplia de forma inovadora a abordagem ecossistêmica dada à política nacional, contemplando ainda as áreas de preservação permanente e as reservas legais como elementos de conectividade entre fragmentos naturais e as próprias áreas protegidas.” (MMA, 2007, p.2122)

Observamos que se passaram dez anos aproximadamente da assinatura da CDB para que o Brasil pudesse reconhecer, em 2004, as 900 áreas prioritárias para melhor definição de políticas públicas para a conservação da biodiversidade. As políticas públicas brasileiras cumprem as metas propostas pela Convenção da Diversidade Biológica, mas não respondem com a celeridade que a questão ambiental requer. Os conflitos se agravam e os prazos, não impostos em tratados ou convenções, passam a ser impostos pela dinâmica da Natureza. A lista de espécies ameaçadas de extinção aumenta a cada publicação, a extensão do desmatamento na Amazônia não cessa e a burocracia dos gabinetes, das políticas, dos programas, dos projetos, tarda a surtir efeitos.

Até 2004, portanto, pela ausência de uma estratégia definida pelo Estado, todos os 149 subprojetos financiados pelo PROBIO foram idealizados por demanda induzida. Ou seja, foram propostos e implementados por iniciativa de grupos isolados, não foram analisados de uma forma ecossistêmica, como a questão da diversidade biológica requer.

Ainda, dos programas apresentados neste capítulo ressalte-se o ARPA, que recebe dinheiro do FUNBIO. 
Quanto ao FUNBIO, se por um lado louva-se o apoio e participação da sociedade através da alocação de recursos externos no ARPA, como forma de contribuir para conservação da biodiversidade no país e no mundo, por outro demonstra-se uma diminuição do poder decisório do governo brasileiro nas questões ambientais.

Quanto ao ARPA, é gerido por um por um Conselho Deliberativo, composto por brasileiros ou não, que, ao fim, gerem e decidem quanto às demandas ambientais, o que pode, ou não, comprometer o interesse público da sociedade brasileira. 


\section{A RESERVA EXTRATIVISTA BAIXO JURUÁ}

Pensar em conservação ambiental pressupõe, no Brasil e no mundo, pensar em áreas protegidas. Inicialmente, pensava-se que a criação de espaços protegidos dotados de belezas cênicas, distantes do homem, seria suficiente para conter o avanço da destruição da natureza. Mas o tempo mostrou que não. A consideração do homem junto ao espaço protegido passou a ser necessária.

Neste capítulo, apresentaremos a Reserva Extrativista do Baixo Juruá como uma alternativa à conservação da diversidade biológica no Brasil, conforme hipótese levantada no início deste trabalho. Por se tratar de uma Unidade de Conservação inserida no Sistema Nacional de Unidades de Conservação, Lei no 9.995/00, uma breve apresentação deste sistema se fará necessária.

Após a apresentação da Reserva, será apresentada ao leitor a descrição pormenorizada de um processo administrativo de criação desta reserva extrativista.

Cabe aqui uma breve explicação do que se pretende com esta minuciosa exposição: desmitificar o modo como uma Unidade de Conservação é criada, para colocá-la no mundo real de conflito de interesses políticos, no caso, regionais.

Fundamentais para o estudo da importância desta Unidade de Conservação são todas as informações contidas no Levantamento Sócio-Econômico realizado em 1998 para embasar a criação da RESEX. 
Por fim, os principais avanços e dificuldades na gestão local são relatados por dois dos três chefes que a RESEX teve até 2007, em entrevistas concedidas à autora. A questão da regularização fundiária, investigada por meio de documentação, foi resolvida a partir de uma entrevista concedida pela advogada contratada pelo IBAMA que trabalha em Brasília.

\subsection{As reservas extrativistas e o Sistema Nacional de Unidades de Conservação}

\subsubsection{Breve histórico do Sistema Nacional de Unidades de Conservação}

Segundo o professor José Affonso da Silva, a preocupação legislativa do Brasil com as Unidades de Conservação surgiu com a criação dos Jardins Botânicos no século passado. O primeiro Jardim Botânico criado foi o do Rio de Janeiro por meio de um Alvará de1811, seguido de outros Jardins Botânicos (em Salvador e Ouro Preto) e alguns Hortos Florestais criados a partir de 1910, como os da Gávea, no Estado do Rio de Janeiro e Lorena, no Estado de São Paulo (SILVA, 2004). Só em 1937, surgiu o primeiro Parque Nacional do Brasil: o Parque Nacional do Itatiaia.

Quanto a uma preocupação efetiva com um verdadeiro sistema de Unidades de Conservação, esta só ocorreu em 1970. Nesta data, foi enviado ao Congresso Nacional um Projeto de Lei para a criação do Sistema Nacional de Unidades de Conservação.

Apesar da recente atenção às Unidades de Conservação, nosso país possui um sistema com aproximadamente 70 milhões de hectares de áreas preservadas. Elas 
são constituídas por Unidades de Conservação e reservas particulares, federais e estaduais, que equivalem a 8\% de nosso território (MMA, 2000).

O problema que se vislumbra frente a este quadro refere-se ao fato de que as áreas oficialmente protegidas não obedecem a um critério de representatividade ao longo dos diversos ecossistemas e biomas brasileiros, resultando em lacunas que reduzem a efetividade do sistema como um todo. Os maiores exemplos destas lacunas são a Caatinga e os Campos Sulinos, que compreendem apenas 1\% da área total protegida em unidades de proteção integral ${ }^{20}$.

De qualquer forma e a despeito de seus problemas, não se podem desconsiderar os avanços ocorridos. A criação do Sistema Nacional de Unidades de Conservação, através da promulgação da Lei nº 9.985/00, conhecida como Lei do SNUC, representou o final de uma época em que a criação de Unidades de Conservação dependia, quase que exclusivamente, de oportunidades políticas surgidas dentro das instituições brasileiras responsáveis pela conservação do meio ambiente e sua legislação.

Com a promulgação da Lei do SNUC, a criação de Unidades de Conservação deve ter como objetivo, segundo o artigo $5^{\circ}$ da citada lei, a criação de um conjunto que represente amostras significativas e ecologicamente viáveis das diferentes populações, habitats e ecossistemas do território nacional e das águas judiciais.

\footnotetext{
${ }^{20}$ Estratégia Nacional de Diversidade Biológica. Contribuição para a Estratégia de Conservação in situ no Brasil GTT 6 .Grupo coordenado por Takako M. Tundisi (CAPES). Revisão dos principais artigos da Convenção sobre Diversidade Biológica, realizada por Grupos de Trabalho Temáticos (GTTs). Disponível em: http://www.mma.gov.br/index.php. - acesso em 25 de março de 2006.
} 
Paulo Affonso Leme Machado (2003, p.761) afirma que a elaboração de estudos técnicos para a criação das Unidades de Conservação deve, necessariamente, obedecer aos princípios do interesse público, da motivação e da publicidade. Deverão afastar, desta forma, procedimentos que porventura visem interesses particulares. E, reafirmando o texto constitucional, ressalta o artigo 22 da Lei $\mathrm{n}^{\circ}$ 9985/2000, que estabelece que a desafetação ou redução dos limites de uma Unidade de Conservação só pode ser feita mediante lei específica ${ }^{21}$.

As Unidades de Conservação dividem-se, segundo o Sistema Nacional de Unidades de Conservação, em dois grupos com características bem distintas.

De um lado, encontra-se o grupo das Unidades de Proteção Integral, que são espaços especialmente protegidos com o objetivo básico de preservação da Natureza. Desta forma, a preservação deve ser integral, completa, não se admitindo qualquer uso direto de seus recursos naturais. Nesta categoria de Unidade de Conservação só se admite uso indireto dos recursos naturais como pesquisa científica ou visitas, mas todas sujeitas a condicionantes e restrições. Este grupo é composto pelas categorias de Estação Ecológica, Reserva Biológica, Parque Nacional, Monumento Natural e Refúgio de Vida Silvestre (BRASIL, 2000).

\footnotetext{
${ }^{21}$ BRASIL, Consituição Federal, Artigo 225:

"Todos têm direito ao meio ambiente ecologicamente equilibrado, bem de uso comum do povo e essencial à sadia qualidade de vida, impondo-se ao Poder Público e à coletividade o dever de defendê-lo e preservá- lo para as presentes e futuras gerações.

$\S 1^{\circ}$ - Para assegurar a efetividade desse direito, incumbe ao Poder Público:

I - preservar e restaurar os processos ecológicos essenciais e prover o manejo ecológico das espécies e ecossistemas;

II - preservar a diversidade e a integridade do patrimônio genético do País e fiscalizar as entidades dedicadas à pesquisa e manipulação de material genético;

III - definir, em todas as unidades da Federação, espaços territoriais e seus componentes a serem especialmente protegidos, sendo a alteração e a supressão permitidas somente através de lei, vedada qualquer utilização que comprometa a integridade dos atributos que justifiquem sua proteção (...)”
} 
De outro, está o Grupo das Unidades de Uso Sustentável, que são também espaços protegidos, porém em menor grau do que as unidades de proteção integral. Isto porque nestas categorias permite-se o uso direto dos recursos naturais. Permitese o uso, mas sempre em regime de manejo sustentável, compatibilizando a conservação da Natureza com o uso dos recursos. Este grupo é constituído pelas categorias de Área de Proteção Ambiental, Área de Relevante Interesse Ecológico, Floresta Nacional, Reserva Extrativista, Reserva de Fauna, Reserva de Desenvolvimento Sustentável e Reserva Particular do Patrimônio Natural(BRASIL, 2000).

Para a geógrafa Neli Aparecida de Mello, até 1990 as políticas públicas referentes às áreas protegidas no âmbito federal privilegiaram a criação de parques nacionais, reservas biológicas e estações ecológicas. Portanto, era dada preferência às Unidades de Conservação que excluíam a presença humana. Entretanto, segundo a mesma autora, pouca importância foi atribuída à regularização fundiária destas áreas, ou seja, à aquisição da propriedade por parte do governo federal, com a justa indenização dos proprietários (MELLO, 2006, p.65).

\subsubsection{Indicadores do Sistema Nacional de Unidades de Conservação}

Com base nos relatórios acima citados, serão expostos dados referentes à implementação da CDB especificamente no que concerne ao Sistema Nacional de Unidades de Conservação. 
Até 1998, ano de publicação do Primeiro Relatório Nacional, 2,61\% do território brasileiro era constituído por Unidades de Conservação de proteção integral e 5,52\% de Unidades de Conservação de uso sustentável. ${ }^{22}$

É importante frisar que a Lei $n^{\circ}$ 9.985, que instituiu o Sistema Nacional de Unidades de Conservação, só foi aprovada no ano de 2000. Até a publicação desta lei, a legislação que regulamentava as diferentes categorias de Unidades de Conservação era constituída por uma malha jurídica complexa, que carecia de uma padronização de linguagem e instrumentos administrativos.

A tabela abaixo traz uma radiografia da conservação in situ em nosso país, até o ano de 1998, cabendo destacar as informações referentes à porcentagem de terras destacadas para a conservação em nosso território.

\footnotetext{
${ }^{22} \mathrm{O}$ artigo $7^{\circ}$ da Lei $n^{\circ} 9.985 / 2000$ traz a definição de unidade de conservação de proteção integral e unidade de conservação de uso sustentável:

Art. $7^{\circ}$ As unidades de conservação integrantes do SNUC dividem-se em dois grupos, com características específicas:

I - Unidades de Proteção Integral;

II - Unidades de Uso Sustentável.

$\S 1^{\circ}$ O objetivo básico das Unidades de Proteção Integral é preservar a natureza, sendo admitido apenas o uso indireto dos seus recursos naturais, com exceção dos casos previstos nesta Lei. $\S 2^{\circ}$ O objetivo básico das Unidades de Uso Sustentável é compatibilizar a conservação da natureza com o uso sustentável de parcela dos seus recursos naturais.
} 
Tabela 1 - Unidades de Conservação federais do Brasil administradas pelo IBAMA

\begin{tabular}{|c|c|c|c|c|}
\hline Categoria & & $\mathbf{N}^{\mathbf{o}}$ & $\begin{array}{l}\text { Área Total } \\
\text { (ha) }\end{array}$ & \% país \\
\hline \multirow{5}{*}{ Uso Indireto } & Parques Nacionais & 36 & & \\
\hline & Reservas Biológicas & 23 & & \\
\hline & Estações Ecológicas & 21 & & \\
\hline & Reservas Ecológicas & 5 & & \\
\hline & Áreas de Relevante Interesse Ecológico & 18 & & \\
\hline Subtotal & Uso indireto & 103 & 15.889 .543 & 1,87 \\
\hline \multirow[t]{3}{*}{ Uso Sustentável } & Áreas de Proteção Ambiental & 24 & & \\
\hline & Florestas Nacionais & 46 & & \\
\hline & Reservas Extrativistas & 11 & & \\
\hline Subtotal & Uso Sustentável & 81 & 23.178.668 & 2,72 \\
\hline Total & Unidades de Conservação Federais & 184 & 39.068.211 & 4,59 \\
\hline
\end{tabular}

Fonte: IBAMA, 1997b.

Uma importante questão apontada neste relatório é que, até o ano de 1998, a maior parte das áreas de proteção integral era constituída com menos de 100 mil hectares. Por este motivo, era difícil manter populações geneticamente viáveis, quando se trata de espécies de grande porte que necessitam de grandes territórios e têm baixa densidade natural.

Também apontado neste relatório como um dos grandes problemas para a implementação do Sistema Nacional de Unidades de Conservação era o pequeno número de funcionários do Instituto Brasileiro do Meio Ambiente e dos Recursos Naturais Renováveis - responsável pela administração das Unidades de Conservação em todo país. Segundo dados do relatório, havia a relação de um funcionário para 27.560 hectares (em média) de áreas protegidas integralmente.

No que se refere ao apoio financeiro internacional, podemos citar o Programa Piloto para a Proteção das Florestas Tropicais do Brasil (PPG7), criado com o intuito de fortalecer e maximizar os benefícios ambientais das florestas tropicais brasileiras, 
de maneira compatível com o desenvolvimento do País. Representa um modelo único de cooperação entre o Governo brasileiro, a sociedade civil e a comunidade internacional. O PPG7 foi instituído por intermédio do Decreto n ${ }^{0} 563$, em junho de 1992, e modificado pelo Decreto $n^{0}$ 2.119, em janeiro de 1997. Sua execução compete ao Governo brasileiro, por intermédio do Ministério do Meio Ambiente (coordenador do programa), do Ministério da Justiça e do Ministério da Ciência e Tecnologia, com a participação do Banco Mundial, da Comunidade Européia e dos países membros do Grupo dos Sete.

Já o Segundo Relatório Nacional para a Conservação sobre a Diversidade Biológica: Brasil traz os seguintes dados:

“Cerca de 2,61\% do território nacional é constituído de unidades de proteção integral (de uso indireto) e 5,52\% de unidades de uso sustentável (de uso direto). Importantes esforços têm sido empreendidos com a finalidade de ampliar as áreas protegidas. A soma dessas categorias totaliza $8,13 \%$ do território nacional. As Unidades de Conservação federais administradas pelo IBAMA somam aproximadamente 45 milhões de hectares, sendo 241 Unidades de Conservação de uso direto e indireto. O Brasil possui as seguintes Unidades de Conservação federais:

31 Áreas Federais de Proteção Ambiental - APAS;

25 Reservas Extrativistas - RESEX;

25 Reservas Biológicas - REBIOS;

29 Estações Ecológicas - ESECS;

60 Florestas Nacionais - FLONAS;

19 Áreas de Relevante Interesse Ecológico - ARIES; 
52 Parques Nacionais PARNAS; e

364 Reservas Particulares do Patrimônio Natural - RPPNs.”(MMA, 2004, p.49)

Ainda segundo o mesmo relatório - que contabilizou o grau de implementação da CDB até dezembro de 2002 - em 22 de agosto de 2002, foi criado o Parque Nacional das Montanhas do Tumucumaque que, com 3.877.393 ha, constitui o maior Parque Nacional do Brasil. O parque detém, ainda, os títulos de maior parque nacional da América do Sul e de maior parque nacional do mundo em área de floresta tropical.

O Segundo Relatório destaca como importante ação, referente ao tema Unidades de Conservação, o Programa Parques do Brasil, gerido pelo Ministério do Meio Ambiente e pelo IBAMA, que tem como principal objetivo o aumento do número e da representatividade das Unidades de Conservação em todo país. Suas principais ações são a implantação de Unidades de Conservação em todo o país, implantação de infra-estrutura ecoturística em Unidades de Conservação, desenvolvimento de técnicas de manejo de ecossistemas brasileiros e gestão, manejo e fiscalização de Unidades de Conservação.

Estranhamente, relata ações realizadas pela Rede Nacional Pró-Unidades de Conservação, como a organização dos Congressos Brasileiros de Unidades de Conservação. Foram realizados três eventos da série: o primeiro, em 1997, na cidade de Curitiba (PR); o segundo, em 2000, em Campo Grande (MS); e o terceiro, em Fortaleza (CE), em setembro de 2002. A estranheza se dá pelo fato da Rede Nacional Pró-Unidades de Conservação ser uma organização não-governamental e 
que, portanto, não deveria constar de um relatório oficial do governo como política pública implementada pelo Estado.

Quanto a recursos estrangeiros, o Segundo Relatório destaca o Projeto Áreas Protegidas da Amazônia (ARPA), que visa à ampliação das áreas protegidas de florestas tropicais no País e será tratado em subitem em separado.

O Terceiro Relatório Nacional para a Convenção da Diversidade Biológica traz os seguintes dados:

"No contexto do esforço federal de conservação da natureza, estão sob a responsabilidade do Instituto Brasileiro do Meio Ambiente e dos Recursos Naturais Renováveis (Ibama), um conjunto de 668 unidades. Somente computando as áreas federais e excluindo as RPPNs, o Brasil dispõe aproximadamente de $7 \%$ de seu território coberto por UCs, sendo 43,02\% de proteção integral e 52,97\% de uso sustentável, totalizando 24,4 e 33,8 milhões de hectares de área protegida, respectivamente." (MMA, 2006, p.77)

Como se pode observar o Ministério mudou o modo de computar as áreas protegidas, pois, diferentemente do Segundo Relatório, não considerou as Reservas Particulares do Patrimônio Natural, talvez pelo fato de serem Unidades de Conservação que não integram o domínio público. Torna-se impossível, portanto fazer qualquer tipo de análise comparativa, uma vez que se alterou a base de dados.

Ressalta, ainda, como realizações do governo a implantação do Fórum Nacional de Áreas Protegidas, instituído em 2004. Trata-se de um órgão colegiado, que tem por finalidade assegurar a participação e o apoio social na elaboração e implementação da Política Nacional das áreas Protegidas. Além disso, relata a implantação de Unidades de Conservação já criadas, com a criação de conselhos 
gestores ou deliberativos, elaboração de planos de manejo, regularização fundiária, eventos, reformas, dentre outras atividades.

Sem dúvida alguma, dentre os três relatórios, é o melhor elaborado no tocante às áreas protegidas porque elenca as ações de implementação das Unidades, com a respectiva atividade desenvolvida. Outras realizações destacadas pelo documento foram a definição das áreas prioritárias para a conservação, utilização sustentável e repartição dos benefícios da biodiversidade e a criação do ARPA, sendo que o primeiro já foi tratado em Capítulo anterior e o segundo será tratado no subitem subseqüente.

\subsubsection{As Reservas Extrativistas e sua inserção no Sistema Nacional de Unidades de Conservação}

Segundo Allegretti (1994), o conceito de reserva extrativista surgiu no primeiro Encontro Nacional dos Seringueiros da Amazônia, no ano de 1985, sendo este conceito apresentado como "áreas para o uso sustentável dos recursos naturais por populações tradicionais, com apoio nas áreas de produção, saúde e educação”.

No âmbito legal, as Reservas Extrativistas foram formuladas, primeiramente, dentro do Programa Nacional de Reforma Agrária e receberam o nome de Projetos de Assentamentos Extrativistas. Tais projetos foram criados pela Portaria $n^{\circ} 627$ do Instituto Nacional de Colonização e Reforma Agrária, de 30 de julho de 1987 (RYLANDS \& PINTO, 1998).

A partir de 1989, os Projetos Extrativistas passaram a ser coordenados pelo Instituto Brasileiro do Meio Ambiente e dos Recursos Naturais Renováveis, tendo 
sido regulamentados pelo Decreto $n^{\circ}$ 98.897, de 30 de janeiro de 1990, recebendo, a partir de então, a denominação de Reservas Extrativistas, e integrando, a partir do ano 2000, o Sistema Nacional de Unidades de Conservação. Hoje, no âmbito federal, são administradas pelo IBAMA, sendo que a Portaria IBAMA nº 51-N, de 11/05/1994 define os procedimentos para implantação deste tipo de Unidade de Conservação.

Apesar da visão retrógrada de alguns, que viam as reservas extrativistas como um verdadeiro instrumento da reforma agrária em si, as RESEX foram incluídas no Sistema Nacional de Unidades de Conservação e hoje, estão previstas como uma das categorias do grupo de Unidades de Uso Sustentável (BRASIL, 2000).

Sucintamente, podemos afirmar que o modelo de extrativismo desta categoria de Unidade de Conservação baseia-se em sistema de produção, que concilia a coleta de produtos florestais com outras atividades como agricultura, caça, pesca ou coleta. Segundo Juliana Santilli, preserva dois valores fundamentais:

“(...) diversidade biológica e proteção aos recursos naturais, por meio de sua utilização sustentável, e a diversidade cultural, uma vez que valorizam e promovem o modo tradicional de apropriação e utilização dos recursos naturais, afastando as práticas das sociedades urbanoindustriais, responsáveis pelos problemas ambientais contemporâneos." (SANTILLI, 2005)

Por outro lado, segundo o roteiro para criação e legalização das reservas extrativistas, estabelecido no anexo da Portaria IBAMA n 51/94, a criação delas deve ter por origem uma solicitação formal dos moradores da área para que a Unidade de Conservação seja criada. Observa-se, neste ponto, um grande diferencial deste tipo de Unidade de Conservação: elas são criadas a partir da vontade dos 
moradores de sua região, havendo, portanto, um animus positivo para criação e, posteriormente, para implantação da unidade.

Com o advento da Lei nº 9.985/2000 e a inserção das Reservas Extrativistas no Sistema Nacional das Unidades de Conservação, é possível, então, defini-las como áreas naturais especialmente protegidas destinadas à exploração autosustentável e conservação dos recursos naturais por populações extrativistas tradicionais.

De acordo com o artigo 18 da Lei do SNUC, a subsistência dessas populações tradicionais deve basear-se no extrativismo principalmente e, complementarmente, na agricultura de subsistência e na criação de animais de pequeno porte. As RESEX têm como objetivos básicos proteger os meios de vida e a cultura dessas populações e assegurar o uso sustentável dos recursos naturais da unidade.

José Afonso da Silva ensina a respeito das RESEX:

"Do ato de criação constarão os limites geográficos, a população destinatária, e as medidas a serem tomadas pelo Poder Executivo para sua implantação, ficando a cargo do IBAMA as desapropriações que se fizerem necessárias. A exploração auto-sustentável e a conservação dos recursos naturais serão reguladas por contrato de concessão de uso real às populações extrativistas tradicionais, a título gratuito, na forma do art. $7^{\circ}$ do Decreto-lei 271, de 1967, prevendo plano de utilização aprovado pelo IBAMA, que conterá cláusula de rescisão quando houver quaisquer danos ao meio ambiente ou a transferência da concessão inter vivos; vale dizer que a transferência causa mortis é permitida." (SILVA, 2004, $p, 246)$

As RESEX serão dirigidas por um Conselho Deliberativo, presidido pelo órgão responsável por sua administração. 


\subsection{O Baixo Juruá}

\subsubsection{Apresentação da RESEX}

A RESEX situa-se nos municípios de Juruá e Uariní, próxima à sede do município de Juruá, a 70 km da confluência do rio Juruá com o rio Solimões. Iniciase na localidade de BOTAFOGO, ao norte, e tem seu limite ao sul na localidade de São Francisco, à margem direita do Rio Juruá. A área encontra-se compreendida entre as Coordenadas Geográficas $3^{\circ} 07^{\prime} 38,1^{\prime}$ ' S e $3^{\circ} 59^{\prime} 57,7^{\prime}$ ' S; $65^{\circ} 41^{\prime}$ 54,5’' W e $66^{\circ} 10^{\prime} 32,3^{\prime \prime}$ W.

O município de Juruá está distante 672 km, por via terrestre e em linha reta, de Manaus; por via fluvial, está a 1.198 km (IBAMA, 1998). O acesso à sede do Município é feito apenas por meio de barco e avião, não havendo linhas comerciais em nenhuns dos meios de transportes.

Figura 4 - Porto do Juruá

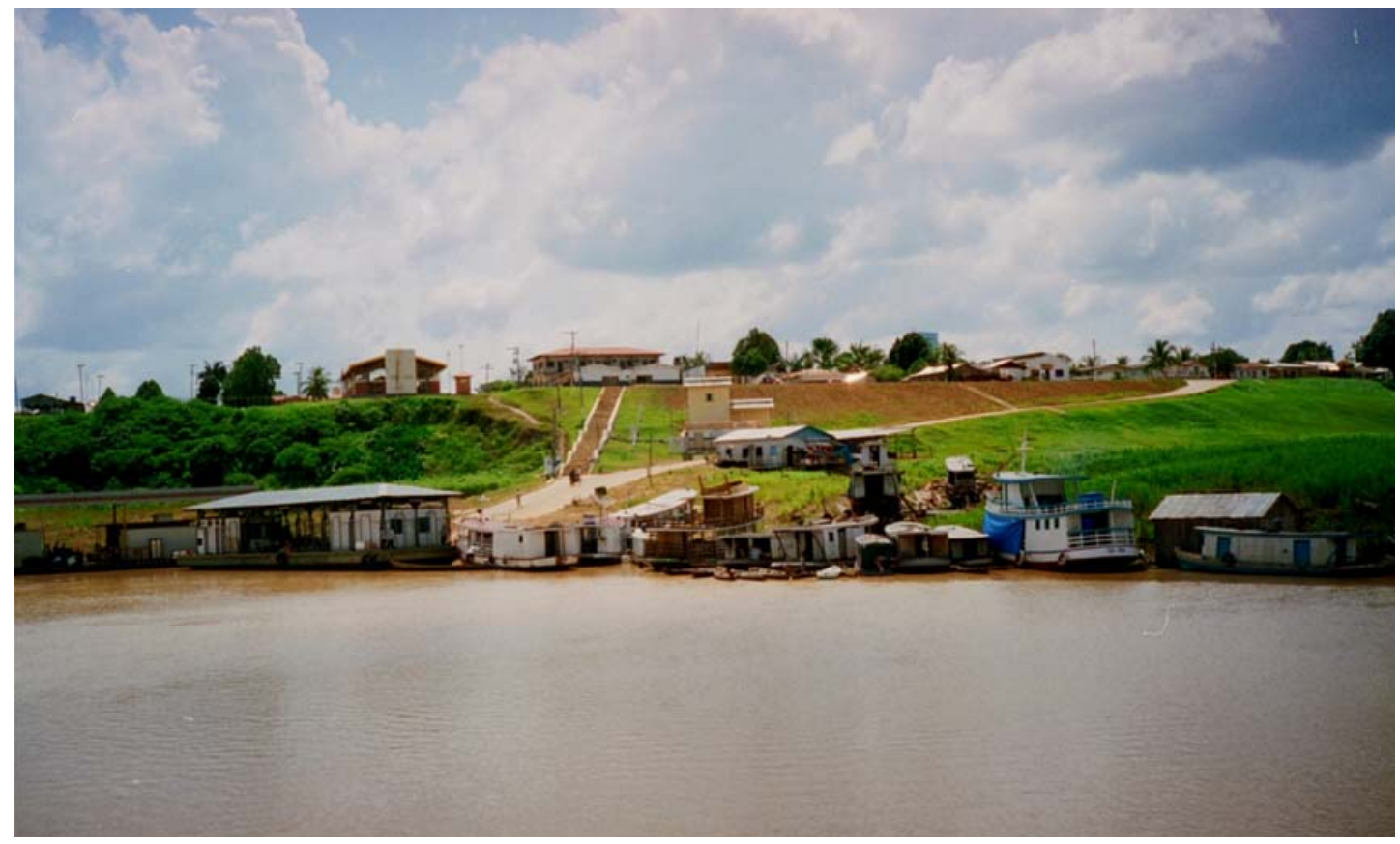

Fonte: Walter Behr, abril de 2004. 
A vegetação da região é classificada pelo IBGE (2004) como Floresta Ombrófila Densa.

Segundo Mantovani (2003), as florestas pluviais tropicais estão presentes no Brasil principalmente nos Estados do Amazonas, Pará, Acre, Amapá, Rondônia e Roraima e áreas dos Estados de Mato Grosso, Tocantins e Maranhão, ocupando aproximadamente $40 \%$ de nosso território. O clima característico desta área possui pluviosidade superior a $1750 \mathrm{~mm}$ e pode chegar a $3500 \mathrm{~mm}$ e temperaturas médias anuais de $24^{\circ} \mathrm{C}$ a $26^{\circ} \mathrm{C}$. Caracteriza-se, ainda, por encontrar-se predominantemente sobre latossolo, ou seja, solo de baixa fertilidade.

Segundo dados constantes do Estudo Sócio Econômico elaborado pelo IBAMA no ano de 1998, documento que embasou o processo de criação da RESEX, na Reserva Extrativista do Juruá estão compreendidos, predominantemente, dois tipos de biomas, o de Várzea e o de Terra Firme, recorrentes na Amazônia.

O mesmo documento define os termos:

"As Várzeas são planícies de inundação que formam uma faixa de largura variável (no rio Juruá é em média de $15 \mathrm{Km}$ ) ao longo do curso do rio. Em certos trechos, a Várzea pode estar ausente e o rio se encaixa na Terra Firme. (...)

As terras de Várzea são extremamente férteis e com boa capacidade agrícola. Elas são utilizadas à medida que chega a vazante do rio (a partir de outubro), quando é feita uma limpeza do terreno e lançadas as sementes. (...)

Especialmente no rio Juruá, há mudanças no leito principal do rio, e os lugares por onde ele deixou de passar (sic!) são chamados de baías, restingas, lagos ou sacados e, por onde abre novos caminhos, furos ou paranás. 
As Terras Firmes são as terras não inundadas pelas cheias que recobrem a maior extensão da planície amazônica (latossolos amarelos). Os solos da Terra Firme, devido à elevada precipitação pluviométrica e à elevada temperatura que impedem a formação do húmus, são muito pobre; nela existe uma floresta heterogênea, que vive sobre um delicado equilíbrio ecológico, quebrado o qual, (sic!) criam-se áreas praticamente inaproveitáveis." (IBAMA, 1998, p.8).

As comunidades que integrariam a RESEX, a partir de sua criação, seriam: Botafogo, Antonina, Aratí, Vai-Quem-Quer, Socó, Forte das Garças I e II, Japó, Andirá (Oito Voltas, Lago Grande e Cumarú), e São Francisco.

Figura 5 - Comunidade de Cumaru

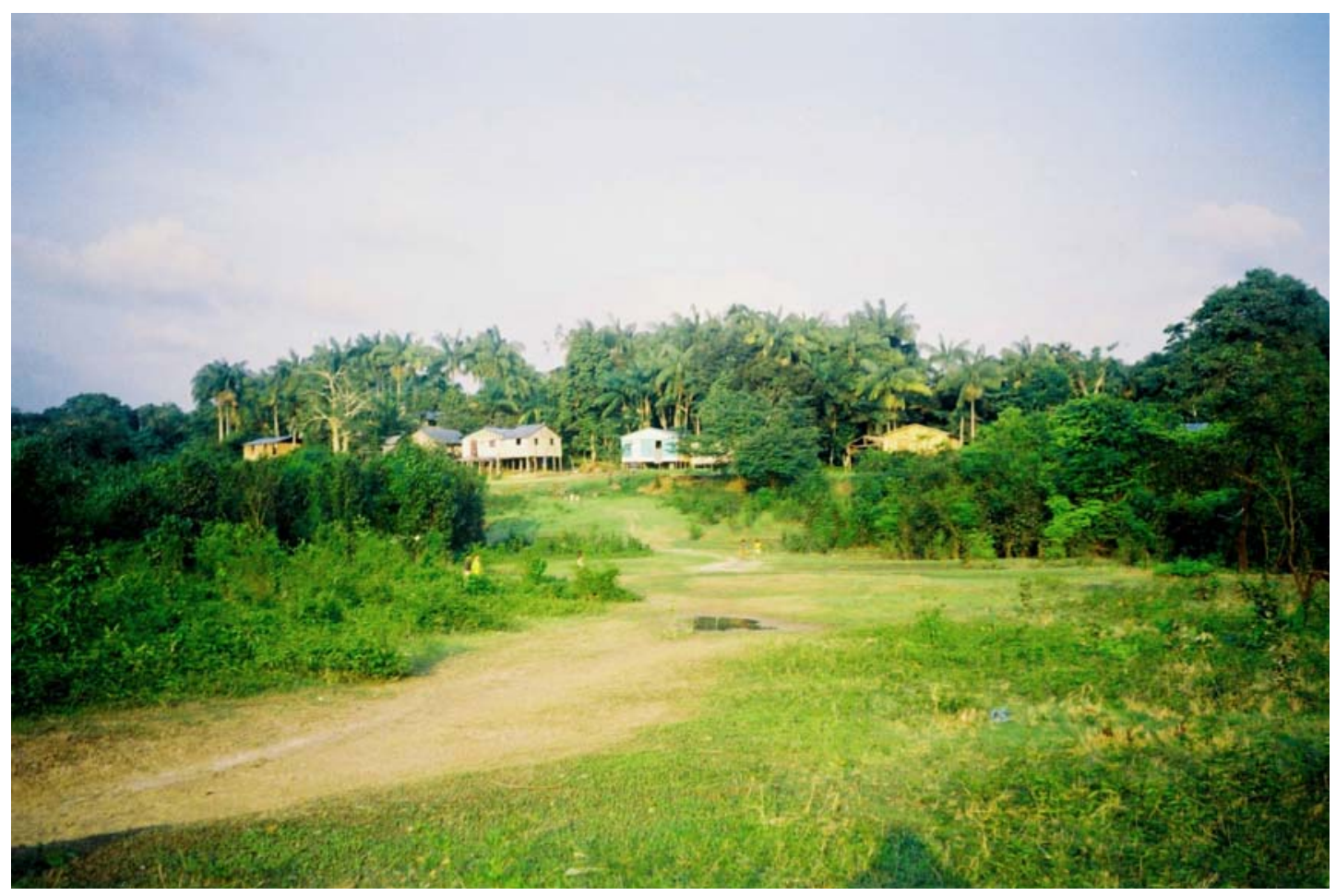

Fonte: Walter Behr, abril de 2004.

\subsection{A vida no Baixo Juruá}

Segundo dados constantes no Levantamento Sócio Econômico da Reserva Extrativista do Baixo Juruá, coletados em 1998, residiam na área da reserva 88 
famílias, somando 563 pessoas no total. As famílias eram constituídas, em média, por 4 a 8 pessoas. Todos os habitantes eram originários do Estado do Amazonas, sendo 84\% do próprio Município de Juruá e apenas 16\% de outros municípios, próximos a Juruá.

O laudo aponta também que, pela análise dos questionários, 30,4\% dos habitantes nasceram e sempre moraram na própria comunidade. Mas verifica-se um grande fluxo migratório dentro do próprio Município de Juruá, comprovado pela alta porcentagem de pessoas que vivem em comunidades diferentes daquela que nasceram (53,6\%). Este fluxo migratório decorre principalmente da busca por melhores condições de vida, em face das crises constantes do mercado da borracha e de outros produtos da floresta.

Entretanto, este dado também se contrapõe a outro dado coletado, que é o de tempo de moradia na comunidade, ou a ancianidade dos chefes de família no local onde residem atualmente. Dos chefes de família, 73,21\% encontram-se na atual comunidade por mais de 10 anos, o que comprova grande ancianidade, apesar de haver um grande fluxo migratório dentro da área do Município

A maioria dos chefes de família (92,8\%) tinha por ocupação principal a agricultura. Tal fato apresentava-se como um desafio a ser enfrentado, pois outros produtos para comércio, poderiam ser extraídos da floresta, de forma racional, respeitando-se seus ciclos de reprodução.

Os moradores da RESEX, em sua maioria, ainda segundo o Levantamento, utilizam a troca de produtos como forma de pagamento. 
Também segundo o mesmo documento, na região (tradicionalmente explorada exclusivamente pelo extrativismo) estabelece-se também a atividade agrícola como atividade de subsistência dos moradores.

Pelo levantamento efetuado na área no ano de 1998, foi possível perceber que a mandioca era a cultura mais explorada pelos chefes de famílias das comunidades, seguida da banana e do abacaxi.

Figura 6 - Produção de Farinha

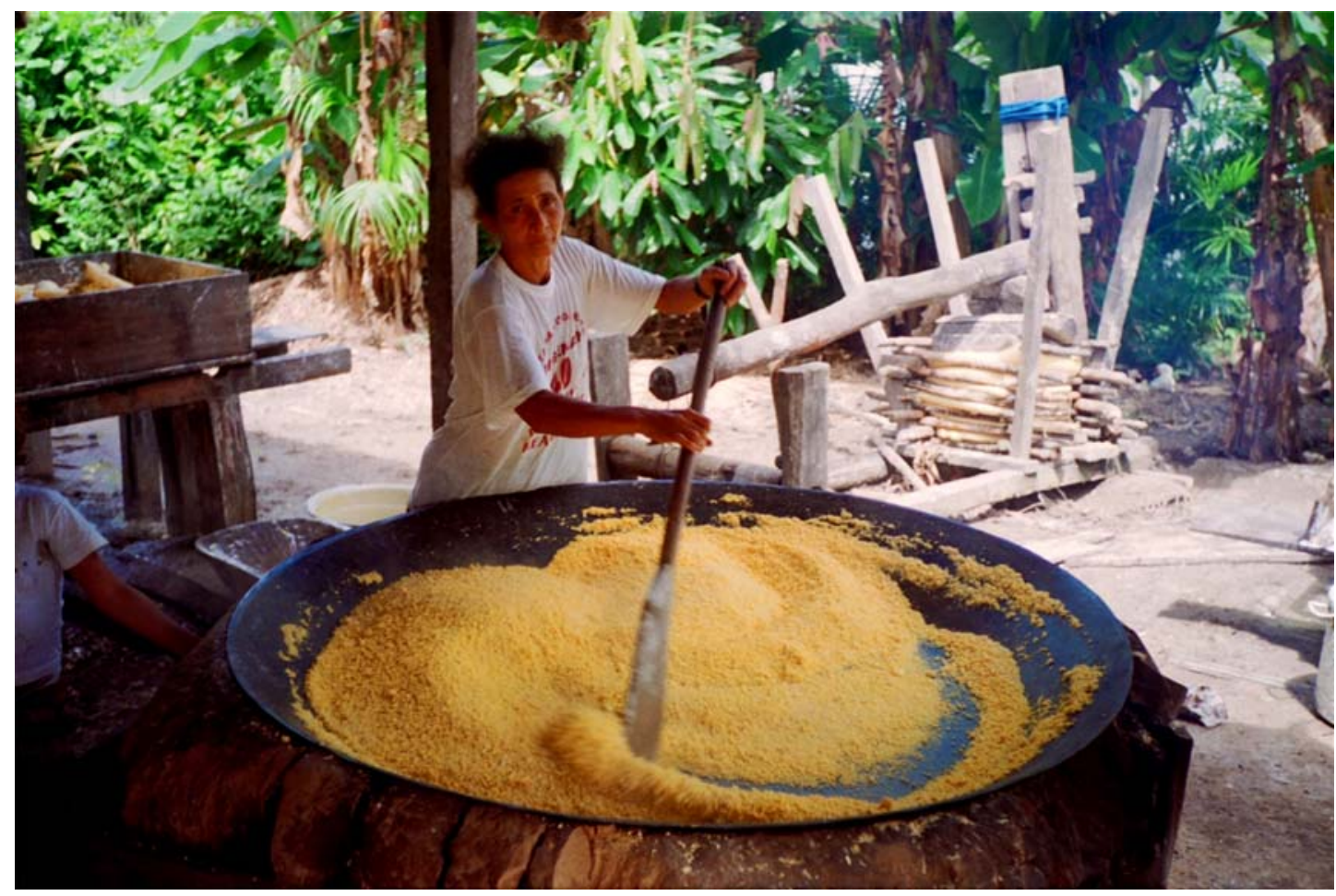

Fonte: Walter Behr, abril de 2004.

O Estudo Sócio-Econômico da Reserva Extrativista do Baixo Juruá, documento oficial do governo federal que embasou os estudos para criação da reserva extrativista, traz quatro parágrafos acerca da produção extrativista da região que serão transcritos abaixo:

“(...) 3.10.3 - PRODUÇÃO AGROEXTRATIVISTA - Torna-se difícil determinar a produção agroextrativista dos moradores da área, uma vez 
que os mesmo, por serem em sua maioria quase analfabetos, não mantendo nenhum controle por escrito (sic!). Assim, os dados obtidos pelo levantamento são apenas uma estimativa, baseada nas informações fornecidas pelos chefes de família entrevistados (56).

A produção extrativista concentra-se em uns poucos produtos, conforme demonstrado nas Tabelas 41 e 42.

Observa-se que o peixe (11.120Kg), a madeira (31.842m3) e a borracha $(5.284 \mathrm{~kg})$, são os produtos mais explorados e, também, os que se destinam quase que exclusivamente para a comercialização (96,4\% do peixe, 99, 8\% da madeira e 100\% da borracha).

Outros produtos extraídos da floresta, como castanha (1.200 kg), açaí (10.200kg) e óleo de andiroba (307 litros) aparece (sic!), também, com alguma importância, sendo que a castanha é quase toda comercializada (90\%): o açaí é consumido, em parte, e o óleo de andiroba é usado, em sua maioria, como remédio ou na fabricação de sabão pelos membros da comunidade.(...).” (IBAMA, 1998)

Como não há linhas comerciais de transporte entre Juruá e outras cidades, os moradores locomovem-se por meio de canoas próprias, ou barcos de vizinhos, e às vezes com o barco da Associação dos Trabalhadores Rurais de Juruá. Em quase sua totalidade, o transporte de passageiros é feito por via fluvial, assim como o transporte da produção.

Com base no questionário aplicado por aqueles que elaboraram o Laudo, apontou-se a falta de transporte e a irregularidade no transporte como os maiores empecilhos para o escoamento da produção dos moradores da região da RESEX do Baixo Juruá. 


\subsection{0 processo de criação ${ }^{23}$}

No processo de criação da RESEX, esteve envolvida, como parte deflagradora do processo, a Paróquia Nossa Senhora de Fátima do Juruá e sua Assessoria Jurídica.

Após a realização de uma reunião na comunidade de Forte das Graças I, no dia 4 de junho de 1997, onde estiveram presentes representantes das comunidades Socó, Forte das Graças I, Forte das Graças II, Lago do Socó, Lago Grande e Cumarú, foi encaminhado o ofício no. 012/97 da Paróquia de Nossa Senhora de Fátima do Juruá e Assessoria Jurídica da Prelazia de Tefé ao IBAMA, solicitando providências no sentido da criação da RESEX.

Nesta reunião da comunidade, realizada em 1997, que contou com a presença do Secretário de Produção do Município de Tefé, representantes do Instituto de Desenvolvimento da Amazônia e representante da Prelazia de Tefé, foi discutida a criação da RESEX. Aqueles que eram favoráveis à criação da Unidade de Conservação justificaram tal posicionamento afirmando que a criação da reserva traria melhores condições de trabalho, saúde, educação e lazer. E ainda, endossaram as palavras do Sr. Claudemir Queiroz, representante da paróquia do Juruá e Prelazia de Tefé, que afirmou que, com a criação da RESEX, as riquezas da região "não escoariam rio abaixo, mas sim ficariam na área beneficiando a região” (IBAMA, 1997a, p.2). A proposta de criação da RESEX foi colocada em votação e aprovada por unanimidade pelos 45 presentes na reunião.

\footnotetext{
${ }^{23}$ Este texto tem por base o Processo Administrativo no 02005.001201/97-33; IBAMA/MMA/GEREX I/AM.
} 
Ainda no mesmo mês de junho de 1997, o então Chefe do Centro Nacional para o Desenvolvimento Sustentado de Populações Tradicionais (CNPT) do IBAMA em Manaus, Sr. Mario Lucio da Silva Reis, deslocou-se até a região, a fim de obter dados mais precisos sobre a intenção da comunidade na criação da RESEX. Em relatório datado de 02 de outubro de 1997, o Sr. Mario Lucio informou que as pessoas residentes na área pretendida para a reserva viviam do extrativismo da borracha em épocas passadas, mas que, naquele ano em que realizou a vistoria, praticavam agricultura de subsistência e um pouco de produção de borracha, pesca e madeira.

Relatou ainda que a região abarcava onze comunidades, sendo que nem todas possuíam associações comunitárias. No total, em 1997, residiam na área, aproximadamente, 103 famílias ou 596 pessoas. E apontou como potencial extrativista seringueiras, madeira, peixe, copaíba e andiroba.

Em 09 de Janeiro de 1998, o mesmo Chefe do CNPT encaminhou memorando ao Chefe Nacional do Centro Nacional para o Desenvolvimento Sustentado de Populações Tradicionais, na sede do órgão em Brasília, Sr. Rafael R. Rueda, informando que havia organizado, em 08 de janeiro, uma reunião no gabinete do Superintendente do IBAMA em Manaus. Estavam presentes à reunião alguns moradores da área em estudo para a futura RESEX no Baixo Juruá, bem como o Vice-Prefeito, o Presidente da Câmara, quatro Vereadores e o Secretário de Transporte, todos do município de Juruá. Todos manifestaram seu apoio ao projeto de criação da Unidade de Conservação e ainda comprometeram-se em participar ativamente do processo de criação. 
O Prefeito Municipal de Juruá, Sr. Tabira Ramos Dias Ferreira, endossou tal assertiva, manifestando seu apoio à criação da RESEX através de ofício encaminhado ao Sr. Chefe do CNPT em Manaus.

Foi juntada aos autos, em maio de 1998, uma certidão emitida pelo Cartório de Registro de Imóveis da Comarca de Carauari, no Amazonas, informando que os imóveis denominados Lago Grande, Cumaru, Andirá, Forte das Graças I e II, Lago do Socó, Socó, Arati, Antonina, Vai Quem Quer e Botafogo, situados à margem direita do Rio Juruá (município de Juruá, Estado do Amazonas), não se encontravam registrados naquele cartório. No entanto, não há informações, nos autos do processo administrativo, de onde surgiram os nomes dessas propriedades, nem tão pouco sua localização. Também não há informação de quem requisitou tais informações ao cartório.

Neste momento, já se observa nos autos a falta de preocupação com uma exata documentação para futuras consultas e estudos como se faz neste momento. O processo administrativo, que ora se analisa, trata-se de documento oficial, único a registrar a formação desta Unidade de Conservação, devendo desta forma, esclarecer a qualquer leitor todos os passos dados até o objetivo final.

Em ofício datado de 24 de setembro de 1998, o então presidente do IBAMA, Sr. Eduardo Martins, informou ao então Presidente do Instituto de Proteção Ambiental do Amazonas, Sr. Vicente de Paula Queiroz Nogueira, a intenção de criar a reserva extrativista do Baixo Juruá, e requereu, ao final, a anuência do órgão estadual. Observa-se aqui uma conduta meramente formal, uma vez que não há 
exigência legal de anuência por parte dos órgãos estaduais, para criação de uma Unidade de Conservação federal.

Já em outubro de 1998, foi juntado aos autos ofício do Diretor Presidente do Instituto Fundiário do Amazonas, Sr. José Maia, encaminhando ao IBAMA plantas contendo a plotagem da área do Baixo Rio Juruá, em cartas planimétricas na escala 1250.000, assim como a seguinte informação da Gerência de Desenho e Plotagem daquele instituto:

“(...) RESERVA EXTRATIVISTA DO BAIXO Juruá, localizada nos Municípios de Tapauá e Tefé e, conforme caracterização, encontra-se inserida em terra do Estado do Amazonas, nas glebas MINERUÁ, matrícula $n^{\circ}$ 612, livro 2-C, fl. 390, de 25.10.1982, e UARINI, matrícula $n^{\circ}$ 1.352, livro 2-C, fl.166, de 21.10.1982. Verificou-se, ainda, que parte da Reserva está inserida em área do Município de Tapauá, conforme determina a Lei $n^{\circ} 1.496$ de 29.12.1981, no seu art. 85, e também um título definitivo, expedido pelo G.E. ${ }^{a}$ em favor de Francisco Antonio S. Pinheiro incide sobre a citada Reserva.”

Dando continuidade ao processo de formação da RESEX, foi enviada consulta à Secretaria do Patrimônio da União inquirindo se na área, objeto do processo, haveria terras pertencentes à União; isto porque, segundo levantamento prévio, fora observado que as terras em referência seriam, em sua maioria, de propriedade do governo do Estado do Amazonas e pequena parte pertenceria ao domínio de particulares.

A Secretaria do Patrimônio da União, por sua vez, inquiriu ao Instituto de Colonização e Reforma Agrária se esta área havia sido arrecadada por eles. Não constam do processo de formação da RESEX as respostas destas inquirições. 
Dando continuidade ao processo de formação da RESEX, em 18 de maio de 1999, a Dra. Nilvanda da Silva Alves de Lima, advogada contratada do IBAMA e que presta serviços no Centro Nacional para o Desenvolvimento Sustentado de Populações Tradicionais, elaborou relatório técnico a fim de analisar se os pressupostos legais para a criação da RESEX haviam sido cumpridos, em conformidade com o artigo $5^{\circ}$ da Instrução Normativa IBAMA n ${ }^{\circ}$ 02, de 16 de outubro de $1998^{24}$.

Terminou por concluir que o processo $\mathrm{n}^{0}$ 02005.001201/97-33 cumpria todas as exigências legais, recomendando por fim a criação da RESEX. Após, enviou os autos à Procuradoria Federal, que deve manifestar-se em todos os processos antes de qualquer decisão final.

Decorrido um ano até que a Procuradoria se manifestasse, foi publicado novo diploma legal, sendo que, analisados os autos pela Procuradoria Federal do IBAMA,

${ }^{24}$ Esta Instrução Normativa foi revogada pela Portaria IBAMA n ${ }^{\circ} 76$, de 14/09/99.

Art. $2^{\circ}$ - A identificação e análise dos fatores sócio-econômico e fundiário das áreas que compõem as Unidades de Conservação a serem criadas ou já protegidas compreendem:

a) Busca documental. Diagnóstico da situação fundiária; manifestação expressa dos órgãos fundiários estaduais e federal que tenham envolvimento ou jurisdição sobre a área, como da Secretaria do Patrimônio da União - SPU, quando as delimitações da área incluírem patrimônio da União; da Secretaria de Assuntos Estratégicos - SAE, quando a área for de interesse da segurança nacional dos Ministérios do Exército e Marinha; do Instituto Nacional de Colonização e Reforma Agrária - INCRA, sobre a existência de concessões de uso, licenças de ocupação, projetos de assentamentos e titularidade do Poder Público; da Fundação Nacional do Índio - FUNAI, quando houver a sobreposição com áreas indígenas; e, Municipais, quando couber;

b) Levantamento nos Cartórios de Registro de Imóveis, em busca de matrículas de imóveis dentro das terras que compõem as Unidades de Conservação;

c) Estudos da área técnica responsável, principalmente a vistoria da área e cadastros onde serão apresentados demonstrativos das bases ambientais e culturais;

d) Diagnóstico da situação fundiária da área;

e) Laudo biológico da área;

f) Levantamento sócio-econômico;

g) Dados Planialtimétricos e georeferenciados (mapas da situação da área, localização e recursos naturais existentes e, Memorial Descritivo do perímetro da área a ser declarada de utilidade pública ou de interesse social e ecológico);

h) Registros fotográficos 
a Dra. Sonia Wiedman, recomendou que eles fossem reanalisados pelo CNPT. Desta feita, em face do Decreto $\mathrm{n}^{\circ}$ 2954, de 29 de janeiro de 1999, que regulamentava a criação das RESEX em substituição à Instrução Normativa $n^{0}$ 02/98, citada no relatório anteriormente mencionado.

Observa-se aqui a repetição do trabalho em face da lentidão administrativa, contribuindo para um processo burocrático e desgastante. Uma vez que o processo ficou paralisado por quase uma ano, e uma nova norma foi editada, os autos tiveram que retornar para serem reanalisados em face da nova norma.

Reanalisados os autos, concluiu-se por sua conformidade com o Decreto $\mathrm{n}^{0}$ 2.954 de 29 de janeiro de 1999, encaminhando-se os autos à Presidência do IBAMA para a efetivação da criação da Unidade de Conservação.

Desta feita, o processo passou pelas mãos da Dra. Nilvanda no dia 25 de maio de 1999 e no mesmo dia recebeu o parecer da Dra. Sonia Maria Wiedmann. No dia 26 de maio de 1999 foi exarado o “de acordo” pela Sra. Chefe da Procuradoria Geral e, no dia 27 de maio de 1999, o Chefe do CNPT/IBAMA, Sr. Rafael Rueda, exarou também sua concordância.

Em 28 de maio de 1999, a então Presidente do IBAMA, Sra. Marília Marreco, encaminhou o processo ao Exmo. Sr. Ministro de Estado do Ministério do Meio Ambiente, Dr. José Sarney Filho com as seguintes considerações:

\footnotetext{
“Senhor Ministro,
}

Submeto à Vossa apreciação, as minutas, ora anexas, da Exposição de Motivos e do Decreto para a criação da Reserva Extrativista do Baixo Juruá, localizada nos Municípios de Juruá e Uarini, Estado do Amazonas. 
A presente proposta, (sic!) torna realidade o aforismo idealizado por Vossa Excelência: "A dimensão ambiental e a dimensão social são indissolúveis." Trata-se de uma área com características de várzea e floresta amazônica, e com exemplares da biota que possibilitam sua utilização auto-sustentável, sem prejuízo da conservação ambiental. Sua população é composta de seringueiros, pescadores artesanais e caboclos, que, organizados em Associação, reivindicam a criação da Reserva Extrativista do Baixo Juruá, porque acreditam que é a melhor forma de proteger os recursos naturais do local.

Nessa área, Sr. Ministro, muitos brasileiros tiveram suas vidas ceifadas em função de doenças como malária, hepatite, tifo, febre amarela, leishmaniose, hanseníase, entre outras. Essas vidas poderiam ter sido poupadas se aquela região contasse com serviços básicos de saúde e educação. Essas e outras situações de carência, (sic!) poderão ser amenizadas e até resolvidas com a implantação da Reserva Extrativista, que tem como pressuposto básico criar condições para que as populações da área implementem um desenvolvimento social, econômico e ambiental, de forma sustentável, e o que é mais importante, sem abandonar seus locais de moradia.

Por oportuno, esclareço que a maioria das terras pertencem ao Estado do Amazonas, restando apenas $0,26 \%$ da área passível de desapropriação, com um valor estimado de $R \$ 12.000,00$ (doze mil reais). Tais recursos orçamentários e financeiros já estão previstos no orçamento do IBAMA, não havendo, portanto, maiores dispêndios para o Governo Federal.

Esclareço ainda que, não obstante o bom relacionamento do IBAMA com o governo do estado do Amazonas na condução dos procedimentos preliminares da criação da RESEX, até esta data o GEA não apresentou anuência da parceria estabelecida, o que denota aceitação tácita.

Assim, e considerando que os estudos levados a cabo pelo IBAMA recomendam a criação de uma Unidade de Conservação naquela área, acreditamos que a oportunidade de decretação da Reserva, vem de encontro (sic!) ao que estabelece o Art. 225, \& $1^{\circ}$, inciso III da Constituição Federal, que incumbe ao Poder Público definir espaços 
territoriais a serem especialmente protegidos, a fim de preservá-los para as gerações presentes e futuras." 25

O processo, junto às minutas do decreto de criação e exposição de motivos, foi encaminhado à Consultoria Jurídica do Ministério do Meio Ambiente, sendo que a Dra. Tânia Maria Pessoa de Deus Fonseca concluiu faltarem os seguintes documentos a fim de se efetivar a criação da RESEX: (a) manifestação expressa do órgão fundiário estadual, vez que 187.491, 47 ha da área em questão, onde seria criada a RESEX, pertenciam ao Estado do Amazonas; (b) manifestação do INCRA quanto à indagação contida no ofício datado de dezembro de 1998; (c) manifestação da Secretaria de Estado de Administração e do Patrimônio, do Ministério de Orçamento e Gestão em razão de um possível envolvimento da União da área em questão; e (d) as certidões de inteiro teor constando a cadeia sucessória e a situação dominial do imóvel nos termos do art. 7º alínea “a”, da IN n 2, de 1998.

Dando continuidade à instrução processual, os autos retornaram ao IBAMA/CNPT para que as providências requeridas pela consultora jurídica do MMA fossem tomadas. Assim, em 06 de agosto de 1999, o Chefe do CNPT do IBAMA Brasília enviou ofício à Secretária do Patrimônio da União, Sra. Maria José Vilalva Barros Leite, requerendo informações acerca da existência de terras pertencentes à União na área em que seria criada a Reserva Extrativista do Baixo Juruá.

Em resposta a este ofício, o Gerente de Área de Empreendimentos Sociais da Secretaria do Patrimônio da União, Sr. Carlos Viriato de Sousa Lima, enviou o ofício ${ }^{25}$ Ofício GP/n ${ }^{\circ}$ 168/99, cuja cópia consta do Processo administrativo IBAMA nº 02005.001201/97, fls
33/34. 
no 081/SPU ao CNPT/IBAMA, em 16 de fevereiro de 2000, informando que, mediante estudos preliminares e à vista dos documentos apresentados, a área da RESEX envolvia terras da União. Informava, ainda, que aquele órgão não se opunha à criação da RESEX, sendo que, após a criação da referida Unidade de Conservação, outras providências deveriam ser tomadas a fim de que a propriedade das terras fosse transferida ao IBAMA.

Paralisado o processo por mais de um ano, em 05 de junho de 2001, foi elaborada uma Nota Técnica pela advogada do CNPT, Dra. Nilvanda da Silva Alves de Lima, informando que o único impeditivo que havia para a criação da RESEX do Baixo Juruá era a falta de anuência do Governo do Estado do Amazonas, o que fugia da alçada do CNPT/IBAMA. Desta forma, sugeria que negociações políticas fossem feitas a fim de viabilizar a criação da RESEX.

Assim, sem maiores informações, foi criada em 01 de agosto de 2001, a Reserva Extrativista do Baixo Juruá.

Como se pode observar desta descrição pormenorizada, não há uma documentação da situação fundiária da região, elaborada previamente à criação da reserva. Este processo - única documentação da criação da reserva - não traz uma ferramenta efetiva que venha a facilitar um posterior trabalho de regularização fundiária, que deveria ser previamente melhor encaminhado.

Observa-se também que, em determinados momentos, o processo encaminhase com velocidade vertiginosa e, em outros, fica paralisado como se não existisse. Pelo que se observa, não há uma regularidade no andamento processual dos processos administrativos desta autarquia e, muito menos, um controle deste 
andamento. Solicitações e requerimentos de pequenas comunidades, como a do Baixo Juruá, ficam a mercê de ingerências políticas.

\subsubsection{A implantação da Reserva Extrativista a partir de 2001}

A Unidade de Conservação passou a existir oficialmente a partir de 2001, sendo que o primeiro analista ambiental a assumir a chefia da unidade foi o Sr. Walter Behr, um administrador de empresas paulista, que ingressou no primeiro concurso realizado pelo IBAMA, em 2002.

Com um histórico ligado ao movimento ambientalista desde 1993, como sócio-fundador da organização não-governamental PRO-BROCAINA e, atualmente, chefe do Parque Nacional do Itatiaia (desde 2005), o Sr. Walter relatou em entrevista concedida à autora em 04 de dezembro de 2007 que ingressou no IBAMA em 2002, com o intuito de trabalhar temporariamente na Amazônia. Foi indicado para trabalhar em uma Unidade de Conservação de uso sustentável, em um local bastante isolado, na Amazônia quase intocada. A RESEX do Baixo Juruá não era uma opção de escolha de trabalho no IBAMA, frente às dificuldades que se impunham, mas para lá foi designado.

Quando chegou a Juruá (dita cidade sede) em 2002, ou seja um ano após a criação da RESEX, não havia nenhuma estrutura. A chegada de um analista ambiental àquela cidade era a chegada do Estado para aquelas pessoas que haviam, em 1997, requerido a criação da RESEX ao IBAMA.

Behr relata que, desde o início, e pelo fato de se tratar de uma Unidade de Conservação cuja criação foi requerida pela comunidade, teve muito apoio dos 
líderes das comunidades, da Prefeitura de Juruá, da Associação dos Trabalhadores Rurais de Juruá, para se estabelecer uma sede ou uma base de trabalho para o IBAMA.

Para tanto, desenvolveu um trabalho que pode ser definido como de educação ambiental, ao informar aos moradores ribeirinhos o que era permitido e o que não era, o que poderia vir a mudar com novos projetos a serem desenvolvidos, com o estabelecimento de algum tipo de proteção aos ataques de pessoas de fora das comunidades aos recursos naturais pertencentes à RESEX.

Todo este contato com as pessoas residentes na área da RESEX tinha por finalidade maior a formação do Conselho Deliberativo.

No ano de 2001, ainda segundo informações de Behr, a principal atividade desenvolvida pelos moradores era a produção de farinha e a pesca, ambas para a subsistência. Já a comunidade de Botafogo fabricava óleo de andiroba em pequena escala.

Behr relata que, em termos de recursos financeiros, durante os quase dois anos em que esteve lá, não houve investimento do IBAMA na RESEX. Diz que, por semestre, o CNPT de Manaus recebia aproximadamente R\$20.000,00, a serem distribuídos por todas as Unidades de Conservação de uso sustentável da Amazônia, o que significava um valor aproximado de $\mathrm{R} \$ 2.000,00$ para cada unidade. Este valor era gasto com suprimentos para viagens para as comunidades, as quais eram feitas no decorrer do ano. 
Durante sua gestão foram apresentados dois projetos ao Fundo Nacional do Meio Ambiente ${ }^{26}$ e, com isso, algum recurso foi disponibilizado.

Os projetos foram inscritos no Edital FNMA $n^{\circ}$ 3/2003. O primeiro aprovado era denominado “Elaboração do Plano de Manejo de Uso Múltiplo”, no valor de R\$ 100.000,00. O segundo aprovado chamava-se “Mobilização Social e Implantação do Conselho Deliberativo da RESEX do Baixo Juruá”, também no valor de R\$ $100.000,00 .^{27}$.

Behr ressalta ainda que o telefone utilizado por ele era pago pela Associação dos Trabalhadores Rurais de Juruá (ASTRUJ). Só ao final de sua estada em Juruá, nos últimos oito meses, que a Gerência Executiva de Manaus passou a pagar a conta telefônica da linha que era o único meio de comunicação do único funcionário do IBAMA na RESEX.

Segundo as palavras do analista ambiental, o fato da RESEX ser próxima da sede do município Juruá é um fator limitante ao crescimento desordenado da cidade, sendo portanto, mais um indicativo positivo da criação da RESEX. Observou:

“A RESEX é criada em torno da cidade, ela está praticamente cercada pela RESEX. Na verdade, é um modelo interessante porque, de certa forma, limita o crescimento da cidade. A RESEX vai, sem dúvida, ser um fator de contenção a um crescimento desordenado, que é o que acontece em geral, nas cidadezinhas que vão tendo crescimento populacional muito grande, e vai avançando sem limites. A RESEX vai obrigar a ter

\footnotetext{
${ }^{26}$ O Fundo Nacional do Meio Ambiente é um fundo público, criado no ano de 1989, para implantação da Política Nacional do Meio Ambiente. Apóia iniciativas da sociedade civil e de órgãos e entidades governamentais que promovam a recuperação, a conservação e a preservação do meio ambiente. Difere fundamentalmente do FUNBIO pelo fato de tratar-se de um fundo público, portanto, está sujeito às regras de direito público.

${ }^{27}$ http://www.ibama.gov.br/ - acesso em 29 de dezembro de 2007.
} 
um planejamento maior na área que não é dentro da RESEX. Achei bem interessante este formato da RESEX aí. „28

Afirma, ainda que os ataques aos recursos naturais de lugares quase intocados como Juruá ocorrem para suprir mercados consumidores de grandes centros urbanos como Manaus e Tefé. Walter Behr relata:

“(...) Como tem muitos lagos e os lagos são muito ricos, então, eram constantemente invadidos e todo este recurso era roubado. Isso é comum na Amazônia. O que acontece, para abastecer o mercado de 2 milhões de pessoas em Manaus, você precisa ter uma enorme frota de barcos, que invade todos os lugares para levar os recursos para Manaus. Quando eu cheguei lá, por exemplo, tinha sido recém capturada uma balsa com 15 mil tracajás, que é uma tartaruga menor, para levar para Manaus. Então, é um ataque ao recurso que é uma coisa inacreditável. A questão da insustentabilidade surge porque o recurso é levado embora. O recurso consumido na região ele é plenamente sustentável, ainda mais se for feito de uma forma organizada. Este era um dos objetivos: você ter uma manejo de lago, onde você, um período em que aquele lago se recupera, o recurso se recupera, enquanto no outro você pesca uma certa quantidade. E eles têm a condição de se recuperar. Organizar, enfim, esta pesca, de forma que sempre haja o recurso disponível, este era o desafio na questão da pesca e ao mesmo tempo dar outras alternativas. "29

Os conflitos envolvendo questões relativas à pesca irregular já haviam sido apontados no Laudo Sócio-Econômico da Reserva Extrativista do Baixo Juruá como o principal problema da região para $73,3 \%$ dos chefes de famílias entrevistados em 1998.

A questão da conservação dos recursos pesqueiros na Amazônia, assim como todas as questões ambientais não podem ser analisadas de forma isolada. Segundo M.

${ }^{28}$ Entrevista do analista ambiental Walter Behr, em 04 de dezembro de 2007.
${ }^{29}$ Idem. 
Goulding (1980, 1981 apud FISCHER et al, 1992), citado no documento Pesca de Águas Interiores, elaborado pelo IBAMA ainda em 1992, estudos ecológicos demonstraram a forte dependência dos peixes em relação aos produtos florestais. Este autor observa que os desmatamentos são o limite para o início da redução dos estoques, sendo um fator mais importante ainda, do que a sobrepesca, na redução dos estoques de algumas espécies. O mesmo documento assevera:

"Os lagos e lagoas marginais são criadouros naturais de várias espécies de peixes, e se constituem em ambientes de extrema importância para outras espécies animais que aí habitam, como os invertebrados, anfíbios, répteis, aves e mamíferos.

Assim, é necessária a proteção destes ambientes, visando à preservação da ictiofauna natural das grandes bacias e da pesca propriamente dita.” (FISCHER et al., 1992, p.21)

Ainda em 2004, foi designado outro analista ambiental para trabalhar na RESEX, o Sr. Paulo Nascimento. Ele trabalhou por um ano na reserva. Durante determinado período, revezou com o Sr. Walter Behr, para que sempre permanecesse alguém em Juruá. Ficou como chefe da unidade por oito meses e, depois, foi transferido para o Rio de Janeiro. Hoje encontra-se em licença sem vencimentos, afastado da carreira de analista ambiental do IBAMA. 
Figura 7 - Sede IBAMA/ASTRUJ construída em Juruá

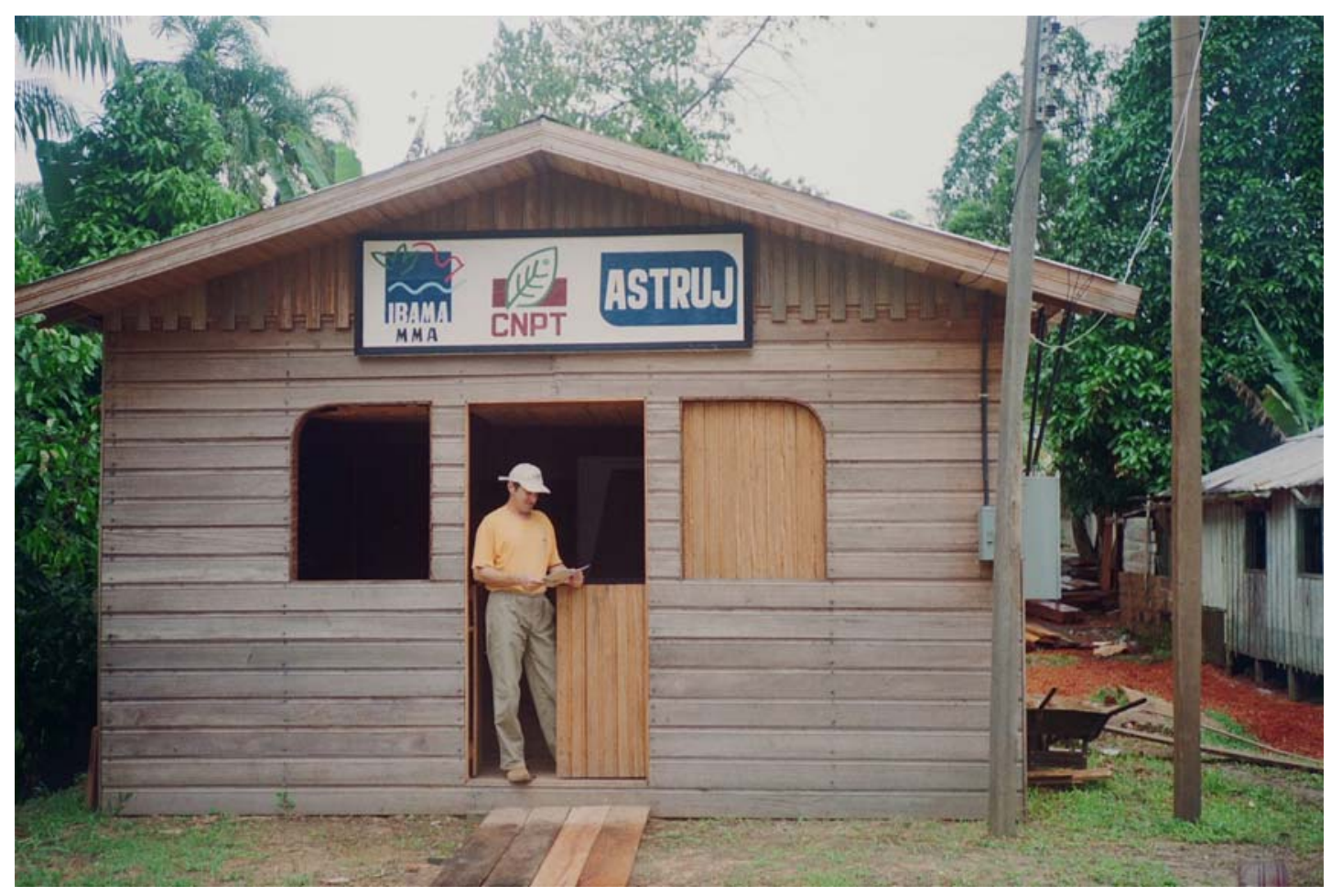

Fonte: Walter Behr, abril de 2004.

Em 2007, residiam na região da RESEX do Baixo Juruá aproximadamente 800 pessoas, segundo informações da atual chefe da Unidade, Dra. Maria Goretti de Melo Pinto. A Associação dos Trabalhadores Rurais de Juruá (ASTRUJ) continua a representar os moradores da RESEX.

Segundo dados constantes do Cadastro Nacional das Unidades de Conservação do Ministério do Meio Ambiente ${ }^{30}$, a Unidade de Conservação possui uma sede fora dos limites da reserva, que funciona com um sistema de rádio e um telefone fixo. Não há comunicação via rede mundial de computadores.

\footnotetext{
${ }^{30}$ http://sistemas.mma.gov.br/cnuc/index.php?ido=uc.formucPortal\&idUC=230 - acesso em 03 de janeiro de 2008.
} 
O meio de transporte utilizado por aqueles que desenvolvem algum trabalho pela Unidade de Conservação é feito por meio de quatro embarcações de pequeno porte também segundo o Cadastro.

A analista ambiental Maria Goretti de Melo Pinto assumiu a chefia da RESEX do Baixo Juruá em 2005. Ela foi classificada para a Região Norte na $1^{\text {a }}$ chamada do concurso do IBAMA daquele ano, que foi realizado, pela primeira vez, de forma regionalizada - portanto, as pessoas concorriam por vagas em determinadas regiões do Brasil. A RESEX do Baixo Juruá foi sua última opção de escolha e lá foi lotada. A Dra. Goretti é formada em Biologia pela Universidade de Brasília, Mestre pela mesma universidade e Doutora em Ecologia pelo Instituto Nacional de Pesquisas da Amazônia (INPA).

Dra. Goretti exerce suas funções como chefe da reserva em Tefé, onde existe um Escritório Regional do IBAMA e viaja para Juruá quando há necessidade.

A analista ambiental relata que, por ser a única funcionária da RESEX, tem de dividir seu tempo entre as questões administrativas (que lhe tomam muito tempo) e as atividades fim da RESEX. Ela define atividades administrativas as questões como prestações de contas, pagamento de aluguel e compra de material, deixando de lado as atividades fim, que especifica como a elaboração do plano de manejo da Unidade de Conservação e a estruturação do conselho deliberativo da RESEX.

O principal objetivo no momento é a finalização do plano de manejo da unidade, que foi desenvolvido por onze consultores contratados separadamente. Quando concedeu a entrevista, em dezembro de 2007, Dra. Goretti havia contratado o último consultor para organizar as informações e finalizar o documento. Depois 
disso, as regras seriam analisadas e discutidas para que o documento final pudesse ser homologado pelo IBAMA.

Apesar de ter como formação acadêmica o curso de Biologia, ao assumir a gestão da RESEX, o IBAMA não procurou capacitá-la como gestora pública. Porém, sua experiência acadêmica com gestão de projetos a auxiliou a administrar a RESEX.

Desde 2005, quando assumiu a chefia da RESEX, Dra. Goretti não recebe nenhuma verba proveniente diretamente do IBAMA, mas sim do ARPA, descrito em subitem do capítulo anterior. Há um orçamento anual previsto, decidido pela diretoria do ARPA, sendo o dinheiro repassado aos chefes das unidades através de uma conta vinculada diretamente à Unidade de Conservação. A verba não passa pelo IBAMA, que é o órgão gestor da Unidade de Conservação.

Dra. Goretti relata que hoje não há mais a presença do madeireiro no Baixo Juruá. O ciclo da borracha ocorreu nas décadas de 1940 e 1950 e não há mais conflitos entre seringueiros e ribeirinhos nesta região do Alto e Médio Solimões. ${ }^{31}$

Os conflitos concentram-se na questão da pesca. Antes mesmo da existência do IBAMA, quando existia apenas a Superintendência da Pesca (SUDEPE) ${ }^{32}$, os

\footnotetext{
${ }^{31}$ A partir de 1860, deu-se o mais importante fluxo de povoamento para a Amazônia, em torno do ciclo da borracha. Nordestinos, principalmente dos sertões do Ceará e do Rio Grande do Norte eram agenciados para trabalharem nos seringais da Amazônia. Os trabalhadores agenciados chegavam aos seringais com a dívida dos custos da própria viagem, e assim tornavam-se ligados ao seringalista que lhes adiantava os utensílios necessários à extração da borracha. Tudo isto mediante a obrigação de entregar aos seringalistas, por intermédio de uma casa aviadora, normalmente estabelecida em Manaus ou Belém, toda a sua produção. A busca incessante de saldo tornava uma verdadeira obsessão dos seringueiros. No entanto, analfabetos, em sua maioria, não conseguiam controlar os mecanismos dos preços, restando a dívida permanente e base do sistema seringalista.
} 
moradores brigavam por restrições maiores que pudessem proteger os recursos pesqueiros da região de grandes pescadores vindos de fora. Os ribeirinhos viam-se prejudicados por aqueles que se deslocavam dos grandes centros urbanos da região, como Manaus e Belém, e se dirigiam aos lagos efetuando grandes capturas de recursos pesqueiros.

Dra. Goretti relata, também, a existência da figura do “dono de lago”. Tratase, normalmente, de um ex-dono de seringal, porém sem título de domínio da terra e, portanto, sem justa propriedade. São os chamados grileiros, que se apropriam de determinada área e assim tomam conta do lago; cobram porcentagem sobre os barcos que deixam entrar no lago que a eles dizem pertencer.

A política atual do IBAMA, segundo ela, não é mais publicar portarias proibitivas de pesca, mas sim fazer acordos de pesca, respeitando-se sempre o ritmo de reprodução de cada espécie. Explica:

"É complexo de realizar um acordo de pesca. É acordo mesmo você tem que ter milhões de reuniões, chegar a um acordo entre todos os usuários, seja o comerciante. Esta é uma figura jurídica para fora da RESEX, para tentar resolver estes conflitos. Outra forma, antes de existirem estes acordos de pesca eram as Portarias, então as comunidades pediam ao IBAMA para fazerem Portarias proibindo a pesca. Existem ainda várias destas Portarias. Hoje o IBAMA não tem mais feito Portaria, não é mais a política atual. Poucas têm saído, mas existem umas em validade, dizendo assim: este lago é proibido para pesca, ou este lago é proibido para pesca comercial, este é um lago de manutenção, ou seja, só é

\footnotetext{
${ }^{32}$ A SUDEPE foi criada em 1962 e extinta em 1988, com a absorção todos os seus funcionários pelo IBAMA. Era o órgão encarregado da política pesqueira nacional e suas atribuições foram transferidas para o IBAMA.
} 
permitida a pesca de subsistência, não pode entrar a pesca comercial. Isto sempre as comunidades procurando o IBAMA para fazer isto. "33

Além disso, como na área da RESEX não há um grande número de lagos, há uma consciência coletiva dos moradores de guardar estes lagos ou, ao menos, estabelecer rodízios para sua exploração (uso de um e repouso dos demais), garantindo a reprodução dos recursos pesqueiros. Os moradores da RESEX fazem um trabalho de guarda do lago e recebem por isto um bônus: uma licença comunitária para pesca do pirarucu, por exemplo, quando o excedente é vendido.

Figura 8 - Paraná do Breu

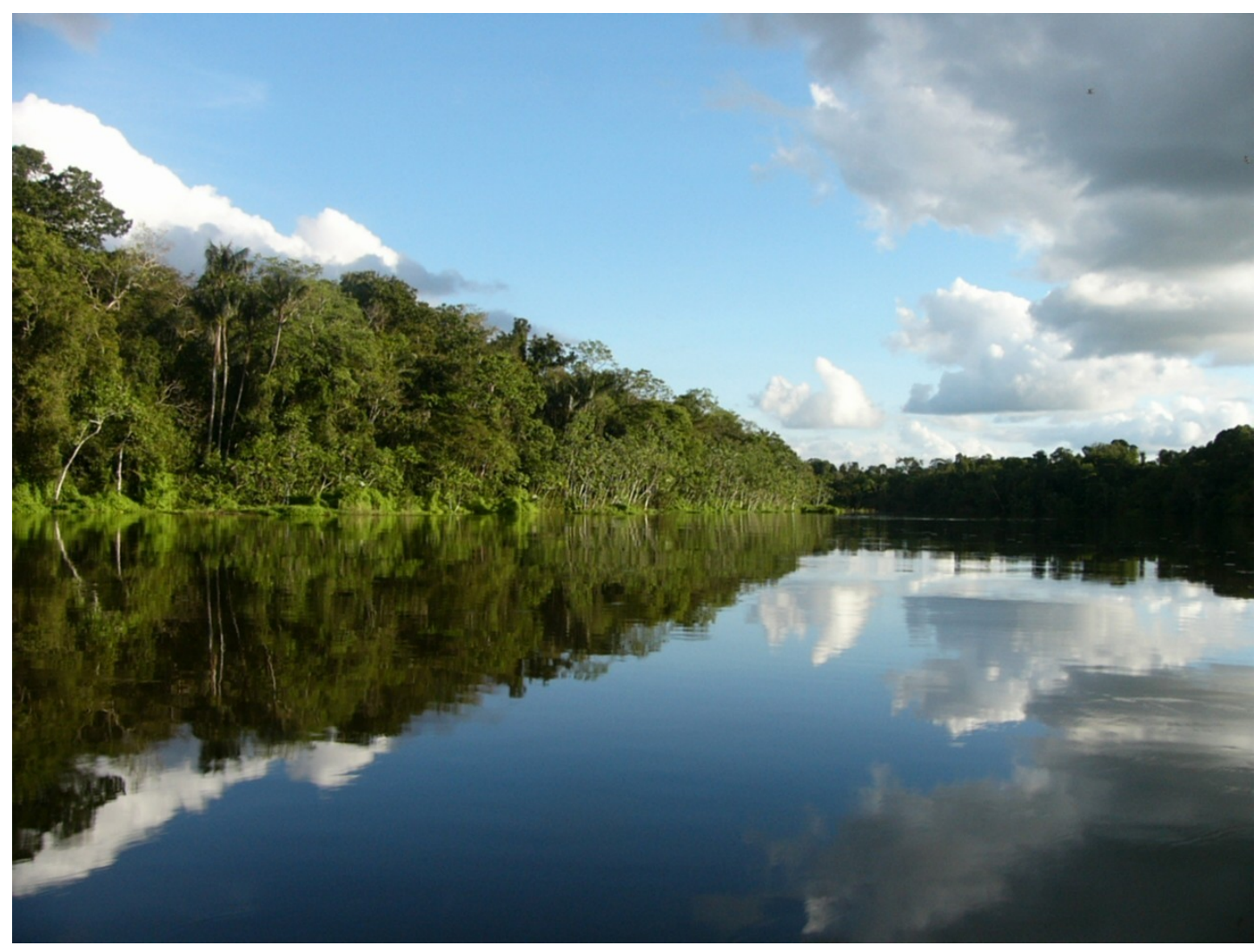

Fonte: Walter Behr, abril de 2004.

\footnotetext{
${ }^{33}$ Entrevista da analista ambiental Maria Goretti de Melo Pinto, em 30 de novembro de 2007.
} 
A principal atividade econômica dos moradores continua a ser a plantação da mandioca e confecção da farinha, principal produto da alimentação de toda a comunidade local. A farinha é consumida e o excedente é vendido ou trocado por outra mercadoria.

Em um artigo publicado em uma coleção editada pelo próprio IBAMA em 2000, a pesquisadora Ana Maira Bastos Neves escreveu sobre a pesca na região Amazônica:

“A fauna de peixes de água doce encontrada na bacia Amazônica é muito diversa. De acordo com Robert (1972), 1.300 espécies de peixes já foram registradas na Amazônia, e Goulding (1980) estima que um número igual está por ser identificado. Entretanto, deste total, apenas cerca de dez espécies representam 93,2\% dos peixes desembarcados nos principais centros de consumo. Este fato gera uma superexploração nos locais de captura dessas espécies comerciáveis, o que leva, paulatinamente, os pescadores a procurarem novas áreas de pesca, cada vez mais distantes dos centros urbanos (Bard \& Imbiriba, 1986)”. (Neves, 2000, p. 90).

Por sua vez, os acordos de pesca, são instrumentos de gestão de conflitos ambientais e têm-se notícias da celebração dos primeiros acordos comunitários de pesca desde os anos 70, segundo dados do IBAMA. Estes primeiros acordos eram realizados pelas próprias lideranças das comunidades, sem qualquer intervenção do Poder Público (AZEVEDO \& APEL, 2004). Atualmente, os acordos de pesca são reconhecidos pela Instrução Normativa IBAMA nº 29/2002, a qual estabelece critérios para o estabelecimento dos mesmos.

Têm-se aqui a concretização da governança, cuja idéia foi apresentada no Capítulo 2 deste trabalho. Trata-se da gestão participativa de um recurso natural, realizada pelas comunidades ribeirinhas, que procuram organizar a pesca e os 
respectivos lagos, fundamentando-se em documentos oficiais de uma instituição governamental.

\subsubsection{A regularização fundiária}

$\mathrm{O}$ artigo $3^{\circ}$ da Lei $n^{\circ} 601$ de 1850 definiu, pela primeira vez, o termo terras devolutas:

\footnotetext{
Artigo $3^{\circ}$ - São terras devolutas:

Parágrafo $1^{\circ}$ - As que não se acharem aplicadas a algum uso público nacional, provincial, ou municipal.

Parágrafo $2^{\circ}$ - As que não se acharem no domínio particular por qualquer título legítimo, nem forem por sesmarias e outras concessões do Governo Geral ou Provincial, não incursas em comisso por falta do cumprimento das condições de medição, confirmação e cultura.
}

Parágrafo $3^{\circ}$ - As que não se acharem dadas por sesmarias, ou outras concessões do Governo, que, apesar de incursas em comisso, forem revalidadas por esta lei.

Parágrafo $4^{\circ}$ - As que não se acharem ocupadas por posses, que, apesar de não se fundarem em título legal, forem legitimadas por esta lei.”

Conforme aponta o procurador do Estado de São Paulo, Ary Eduardo Porto, a definição de terras devolutas se faz por exclusão: são terras devolutas aquelas que não estiverem enquadradas nessas hipóteses legais. Esse autor afirma que a mesma lei, além de definir terras devolutas, estabeleceu os modos de reconhecimento do domínio privado, de regularização das situações ditas irregulares e da situação dominial (PORTO, 1999). 
Da análise do artigo 26 da Constituição Federal de 1988 conclui-se que, por regra, a titularidade das terras devolutas é dos Estados. Terras devolutas só serão federais em casos excepcionais, desde que finalidades específicas previstas no inciso II do artigo 20 da CF, estejam presentes.

Segundo a Dra. Nilvanda da Silva Alves de Lima, entrevistada no dia 02 de outubro de 2007 na sede do IBAMA em Brasília, toda a área da Reserva Extrativista do Baixo Juruá pertence ao Estado do Amazonas, por se tratar de terras devolutas. Esta informação já constava no processo de criação. Não há, segundo pesquisa efetivada no sistema operacional do IBAMA, nenhum processo que documente tal informação.

Entretanto, segundo a mesma advogada, por problemas políticos, não há interesse do governo estadual em transferir a propriedade daquelas terras ao governo federal para que a regularização fundiária da RESEX se efetive. Desta forma, não se vislumbra, ao menos por enquanto, a possibilidade dos moradores da RESEX obterem a concessão de uso das terras, o que também abre espaço para a ação de eventuais "grileiros".

\subsection{Os relatos sobre a vida após a criação da Reserva}

Sr. João da Silva Ferreira conta, em entrevista concedia em 31 de dezembro de 2007, que nasceu em uma pequena comunidade a quinze minutos da cidade de Juruá. Mudou-se de lá aos dois anos e foi criado em Botafogo, onde morou até os trinta anos, quando se mudou para Juruá, para que os seus cinco filhos pudessem estudar. 
Em 2007, era presidente da ASTRUJ, mas trabalha na associação desde que sua criação, desenvolvendo atividades diversas e sempre procurando conscientizar os moradores da região de que a forma associada é sempre a melhor forma de promover as reivindicações dos moradores da área. Assim, participou ativamente da proposta de criação da Reserva Extrativista para colher os frutos de seu trabalho seis anos depois.

Sr. João relata que, com a criação da reserva, a vida dos moradores da região mudou para melhor: “hoje eles têm antena, alguns têm geladeira”34. Perguntado sobre o que a antena e a geladeira têm a ver com a reserva, ele não titubeia em responder que, com a reserva, o dinheiro “começou a rolar mais na região.”35

Assim como os demais moradores de Juruá, fabrica a farinha para consumo, e vende o excedente. Como trabalham de forma associada, vendem o excedente através da associação. Mas, para vender o excedente, como presidente da associação, tem de se locomover até um grande centro urbano como Tefé ou Manaus, o que significa, no mínimo, 40 horas de barco (tempo da viagem até Tefé). E, então, ao retornar, divide os lucros entre os associados. Diz que o Regatão quase não existe mais $^{36}$.

\footnotetext{
${ }^{34}$ Entrevista do Sr João da Silva Ferreira, presidente da ASTRUJ, em 31 de dezembro de 2007.

${ }^{35}$ Idem.

${ }^{36}$ Regatão, segundo o Sr. João, eram os barcos que funcionavam como lojas que colocavam seus produtos a bordo e saíam vendendo pelas comunidades. Da mesma forma, compravam os produtos que os ribeirinhos tinham para vender, como a farinha, por exemplo. Eram pessoas de outras cidades que faziam isso.
} 
Afirma que os donos de lagos continuam a existir, mas nunca existiram dentro da área da reserva. Portanto, a criação da reserva não influiu em nada, nem intimidou aqueles que continuam a agir fora dos limites da RESEX.

Sr. João diz que o maior objetivo da ASTRUJ, no momento, é também finalizar o Plano de Manejo da RESEX, para que as regras de trabalho possam ser discutidas e acertadas, ampliando-se assim, o leque de opções de obtenção de recursos financeiros.

Reafirma que o trabalho da ASTRUJ, conjuntamente com o IBAMA, torna tudo mais fácil. Exemplifica com uma invasão de índios ocorrida recentemente (não soube pormenorizar a data), em que contatou a chefe da RESEX, Dra. Goretti, que imediatamente contatou a Fundação Nacional do Índio (FUNAI), que interveio e conseguiu que os índios saíssem pacificamente da área da RESEX. Segundo suas palavras, os índios ocuparam uma área que era coberta por capoeira e, por isso, o desmatamento não foi muito grande.

Enfim, Sr. João resume as melhoras com a RESEX:

"Teve menos (desmatamento) eu acho. As pessoas a gente sempre aconselha a desmatar na capoeira a aproveitar mais onde já está desmatado.

Melhorou (a pesca) porque agora a gente tem mais o apoio. Quando não era reserva, a gente não podia fazer nada quando o invasor entrava. Agora tem os agentes ambientais e mesmo a gente começou a tirar o pirarucu que ninguém podia tirar. Agora a gente já começou a tirar para vender. Porque agora, durante o manejo de pesca, o pirarucu, o tambaqui, matuxã, nós produzimos na reserva na base de $R \$ 100.000,00$, divididos para as comunidades. Aí melhorou porque não é mais para 
uma pessoa só que é o peixeiro, que é só ele mesmo que ganha. Assim a comunidade inteira ganha."37

Figura 9 - Macaco da Noite

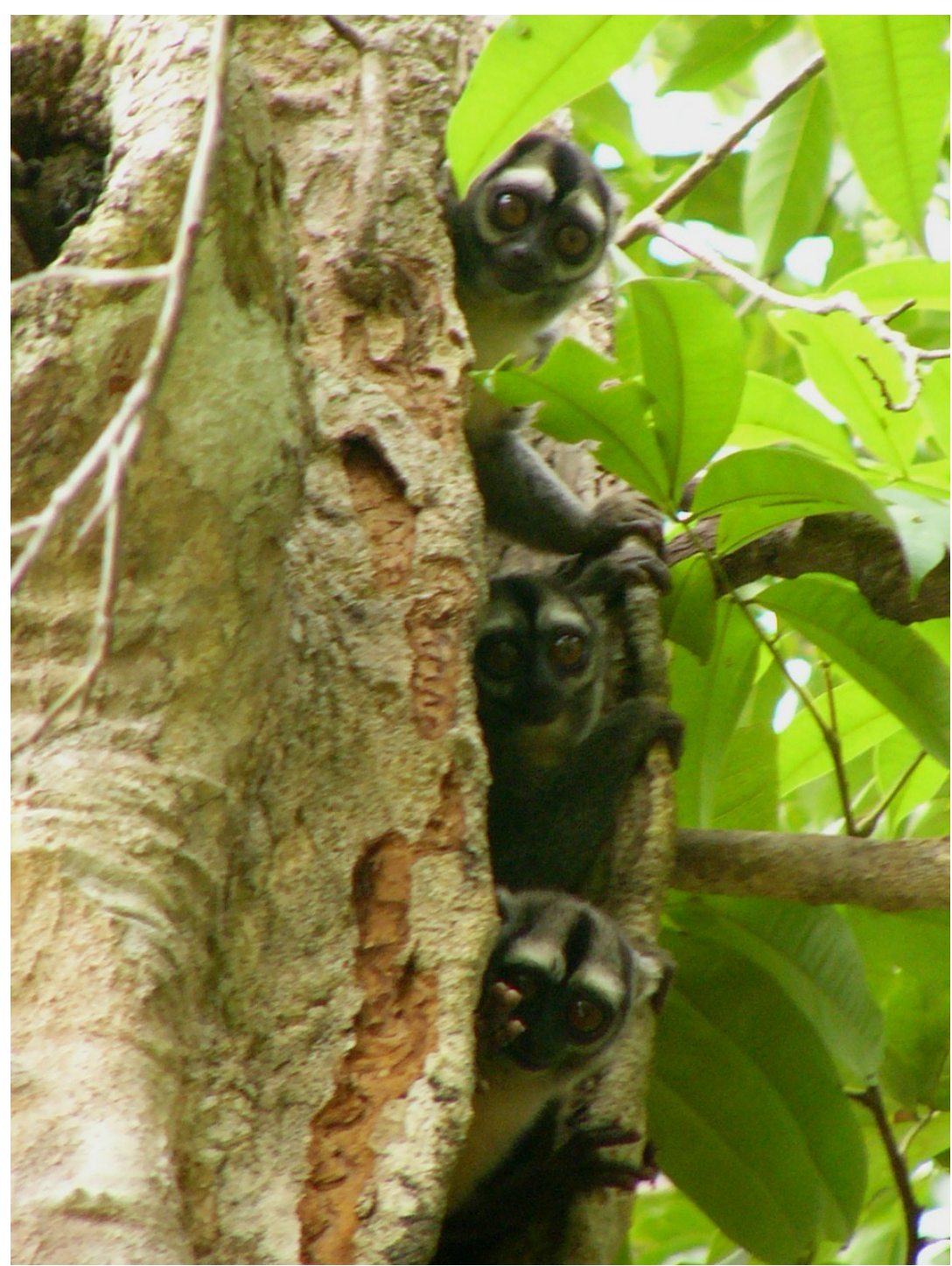

Fonte: Walter Behr, abril de 2004.

Luiz Rocha Maciel tem 27 anos e é acadêmico de engenharia florestal da Universidade Estadual do Amazonas. Também possui formação como técnico ambiental e técnico em pesca. Nasceu em uma comunidade chamada Pupunha, “próxima” a Juruá, segundo suas palavras, que fica a 200 km da sede do município.

\footnotetext{
${ }^{37}$ Entrevista do Sr João da Silva Ferreira, presidente da ASTRUJ, em 31 de dezembro de 2007.
} 
Morou em Pupunha até os quinze anos, tempo em que ajudou seu pai no trabalho de pesca e fabricação da farinha. Aprendeu a ler e escrever em casa, durante o tempo em que morou em Pupunha, sem professor: seu pai pedia a todos que chegassem em sua casa que lhe passassem alguma lição para que ele aprendesse a ler, escrever e fazer as quatro operações básicas de matemática.

Por isso, quando chegou à cidade de Juruá, com aproximadamente quinze anos, pôde cursar a $3^{\mathrm{a}}$ série do Ensino Fundamental. Quando cursava a 6a série, passou a trabalhar em um órgão governamental, denominado Instituto de Desenvolvimento Agropecuário do Estado do Amazonas (IDAM), onde despertou sua curiosidade pelas questões ambientais, pois, desde pequeno, via a degradação ambiental a sua frente, sem qualquer penalização. Além disso, também em sua infância, escutava o relato de seu pai sobre vários recursos naturais, principalmente pesqueiros, que existiam em abundância e que estavam se esgotando.

Quando terminou o Ensino Fundamental, prestou um tipo de vestibular para a Escola Técnica de Manaus e ingressou no curso de pesca. Formou-se em 2001. Acompanhou todo o processo de criação da RESEX, mesmo estando em Manaus, com o apoio do Felipe Tinin.

Voltou a Juruá em 2004, para terminar seus estágios, mas, por incrível que pareça, o IBAMA não pôde aceitá-lo como estagiário na reserva onde nasceu. Já em 2005, para concluir outro curso, o de pós-técnico florestal, passou dois meses na reserva de Mamirauá.

Indagado diretamente se as coisas mudaram com a criação da reserva extrativista, Luiz é categórico: mudou para melhor. E explica. 
"Com certeza. Vou dar exemplo: em 2000 ou 2001, quando eu estava em Juruá, sempre eu saía para pescar no final de semana, quando eu tinha folga. Eu saia para pescar onde hoje é reserva, né, então você tinha muita dificuldade pra capturar mesmo pescado pequeno, e hoje a gente consegue ver isso com facilidade. É tanto que foi retirado aí, quinze toneladas de pescado este ano, graças a Deus e tem muito mais pra ser retirado no ano que vem, então a recuperação está sendo muita rápida, graças a Deus, com o empenho dos meninos da associação, que colocam pessoas, os próprios moradores, através de cursos de capacitação de agente ambiental em parceria com o IBAMA. Treinar essas pessoas para que façam monitoramento nos locais apropriados, não para que a gente consiga inibir cem por cento, porque a área é... Tem invasões que vêm de outros municípios, daqui mesmo da sede do município tem pessoas que são contra e vão lá invadir, perturbar, inventam fofocas, mandam cartas pra fora pedindo anulação da reserva."38

Também aponta o fato de que a criação da reserva traz oportunidades de trabalho para aqueles que antes eram apenas explorados, por exemplo, pelos barcos peixeiros de fora. Além disto, a união entre INCRA e IBAMA possibilitou o assentamento de várias famílias e a possibilidade de obtenção de casas com documentação regularizada.

Relata, ainda, que houve áreas de desmatamentos de até 100 ha em local bem próximo da RESEX. Mas, não há fiscalização adequada para impedir estes fatos. Sete anos após a criação da reserva, aponta as principais reivindicações dos moradores:

“Ela (ASTRUJ) tem que exigir o mais rápido possível do IBAMA, já que está tudo legal, o Plano de Manejo, o plano de uso geral e a presença do IBAMA também. Eu sei que a burocracia que houve com este Instituto aí o Chico Mendes, a gente não sabe como vai ficar, mas seria essencial a presença das meninas aqui, ou a Goretti, ou a outra agora, que eu não lembro o nome. Nem que ela passasse dez dias a cada mês aqui, ou cinco

${ }^{38}$ Entrevista de Luiz Rocha Maciel, acadêmico de engenharia florestal da Universidade Estadual do Amazonas e morador da região da RESEX, em 03 de janeiro de 2008. 
dias, mas seria muito importante. E para ter agilidade no serviço tanto do IBAMA, quanto da associação, nos projetos, ver onde estão os recursos alocados, para conseguir benefícios para a área da comunidade, seria uma Internet, para a gente ter mais agilidade. Porque hoje a nossa dificuldade é ter que mandar por correio um projeto para chegar em Brasília que leva aí quase três meses. Outra coisa importante seria a mão-de-obra: começou por mim, voltei mas tive que sair. Ter uma pessoa aqui, com o mínimo de conhecimentos para ajudar os meninos aqui. Por isto que eu falo, a presença do IBAMA seria muito importante, porque a associação não tem como bancar ninguém, um funcionário para ficar fixo para este conhecimento, para fazer elaboração de projetos, ter uma agilidade maior nestas transações bancárias, na documentação, que a senhora sabe, sempre leva um pouco de burocracia. Então tem que ter uma pessoa com conhecimento para que esse serviço seja o mais agilizado e saia os projetos com maior rapidez. "39

Sobre a riqueza da vida desses ribeirinhos, e sobre o olhar, por vezes distorcido, que são lançados sobre eles, Carlos Walter Gonçalves ensina:

"Um primeiro procedimento que se torna necessário, e que, no entanto, é um dos maiores obstáculos, é o de rompermos com a visão colonialista que até aqui tem predominado e que vê a Amazônia como um espaço a ser conquistado, como se fosse um vazio demográfico e cultural. É essa visão que tem salientado que a região precisa ser mais conhecida, como se já não houvesse um conhecimento acumulado por suas populações originárias e pelos cientistas e pesquisadores que atuam na região. Como essas populações nem sequer foram consideradas como habitantes, afinal a região não é vista como um vazio demográfico? Como considerá-las passíveis de terem construído um patrimônio cultural? Esse talvez seja o grande recurso de que a Amazônia dispõe: o seu patrimônio cultural. E esse patrimônio cultural, em si mesmo diversificado, se confunde com a enorme riqueza das florestas, dos seus ecossistemas. Inventariar o patrimônio desses ecossistemas sem partir da cultura dessas populações é, rigorosamente falando, procurar agulha no palheiro." (GONÇALVES, 2005, p.40).

${ }^{39}$ Entrevista de Luiz Rocha Maciel, acadêmico de engenharia florestal da Universidade Estadual do Amazonas e morador da região da RESEX, em 03 de janeiro de 2008. 
Figura 10 - Comunidade Antonina

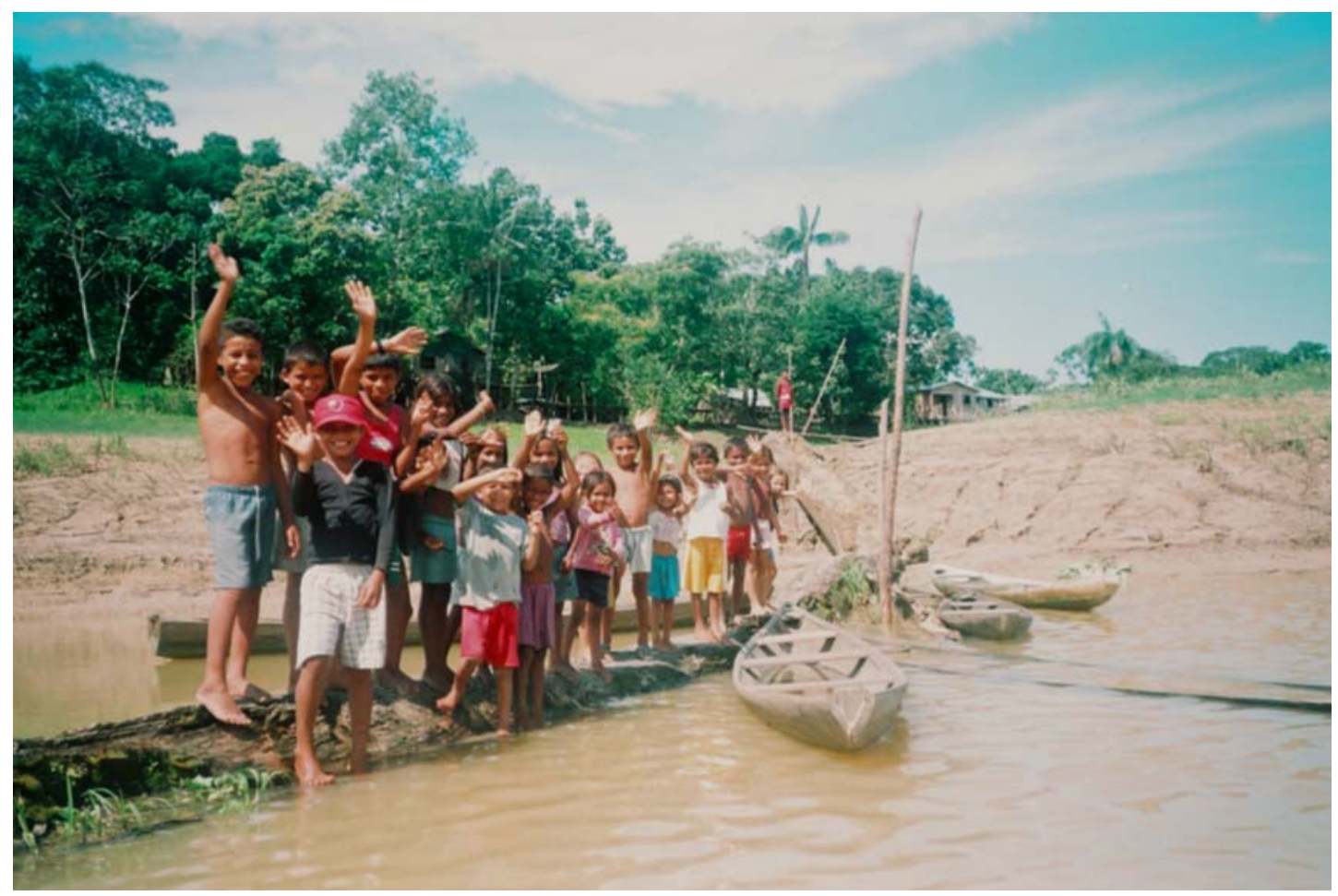

Fonte: Walter Behr, abril de 2004.

A criação da RESEX constitui-se, desta forma, numa legítima intervenção do Estado na proteção ambiental de áreas por demanda das comunidades locais que, certamente, são os principais responsáveis pela conservação desses ecossistemas até o momento.

A implantação da RESEX do Baixo Juruá permitiu a realização de pequenas atividades que, somadas, contribuem para conservação da biodiversidade local. Como exemplo, podemos citar a realização do Levantamento Sócio-Econômico, que colheu informações preciosas acerca da região ainda no ano de 1998; o encaminhamento do Plano de Manejo, mesmo que não finalizado ainda em 2007; a promoção do debate sobre a pesca manejada e a restrição ao uso predatório 
desordenado deste recurso para mercados vizinhos. Enfim, a criação desta Unidade de Conservação possibilitou a organização das comunidades que a compõem, compatibilizando a obtenção de maiores recursos financeiros com a conservação do ambiente local.

Mas, tão importante quanto a conservação da diversidade biológica foi o contato com a diversidade cultural presente no modo de vida do morador do Baixo Juruá. Conhecer o seu modo de vida, e aprender com ele é, sem dúvida alguma, o caminho mais curto para a conservação da Amazônia. 


\section{CONCLUSÃO}

É inegável que a entrada em vigor da Convenção da Diversidade Biológica trouxe ao cenário mundial a discussão de assuntos como o conceito de diversidade biológica, sua conservação, o uso de seus recursos e a divisão do lucro pelo uso de seus recursos. Se o texto desta Convenção Quadro, em vigência desde 1992, não agradou aos mais fervorosos defensores dos direitos das populações tradicionais, é certo que abriu caminho para que estas populações pudessem falar e serem ouvidas.

A CDB segue seu rumo: com a realização das Conferências das Partes, novos fóruns são abertos, novas discussões são colocadas em pauta e o cerco ao redor dos que trabalham contra uma dinâmica de uso sustentável do que ainda temos em 2008 como recursos naturais, procura se fechar, para que estes passem a ser exceção e não a regra. É exatamente neste contexto que o Brasil se insere.

Como signatário da CDB a partir de 1992, o país cumpriu com a tarefa que lhe foi designada: a CDB estabelece prazos bem maleáveis para o cumprimento de suas metas e, o mais importante, não há sanção para o descumprimento. Os programas, projetos e políticas apresentados no Capítulo 4 deste trabalho demonstram que o trabalho vem sendo feito.

A grande questão que resta é: com que velocidade? Nesta toada haverá tempo para conservar e manter-se como um país megadiverso? 
Foram quase dez anos, desde a assinatura da CDB até que se estabelecessem as áreas prioritárias do país. O PROBIO, porém, já atuava desde 1996 com alocação de recursos e não apresentou quais métodos foram utilizados para a escolha daqueles projetos. O planejamento da época não foi apresentado e não está disponível até este momento.

Por outro lado, a Política Nacional da Biodiversidade, instrumento de orientação para o poder executivo, só foi publicada em 2006. Foram várias reuniões de discussões, que tentaram atrair a atenção da sociedade civil para que o debate fosse o mais amplo possível. Méritos, sem dúvida, para seus elaboradores, que procuraram legitimar ao máximo as ações governamentais.

Mas, não se pode esquecer que a PNB servirá como instrumento de trabalho para operadores do direito e, desta forma, merecia um texto prático, coeso, operacional. O Brasil cumpre suas obrigações junto à CDB, mas sofre com seus problemas institucionais, burocráticos, legais.

Há muito se observa que as políticas públicas no Brasil distanciam-se, cada vez mais, do atendimento ao interesse comum. O homem público, pelo que se percebe, não conduz a administração a realizar o bem comum. Várias causas são apontadas, dentre elas a inoperância do sistema administrativo que persiste.

Leis e mais leis são discutidas e aprovadas no Congresso como se fossem resolver problemas emergenciais, mas a máquina usada para operacionalizar estas leis continua arcaica, lenta, desestruturada. A reforma administrativa não anda.

Com isso, o grande ator da esfera ambiental no Poder Executivo, ou seja, o Ministério do Meio Ambiente, já mudou sua organização por seis vezes em quinze 
anos de existência. Foram seis decretos alterando sua estrutura administrativa desde 1992, ano de sua criação. Mas será que o problema estaria mesmo na estruturação do Ministério, que necessitaria de tantas reformas para que funcionasse melhor?

Este trabalho indica que não. De todos os documentos pesquisados, toda a legislação lida, observa-se que nosso país padece de uma burocracia arraigada, uma forma repetitiva de conduzir seus passos. E esta lentidão é inversamente proporcional à velocidade da destruição da diversidade biológica do nosso país.

Aí nos defrontamos com o Sistema Nacional de Unidades de Conservação. Uma grande vitória para aqueles que, de alguma forma, lutam pela conservação ambiental. O primeiro, mas um importante passo. Com ele, as reservas extrativistas foram alçadas à categoria de Unidades de Conservação. Uma enorme vitória aos antigos seringalistas, precursores da luta pelas reservas.

O Baixo Juruá aparece para demonstrar que o trabalho pontual, cotidiano, quase ingrato, surte efeitos. A vida dos ribeirinhos pode ser melhorada, basta que se recuperem os recursos naturais, parte dos quais já são escassos. Assim, eles talvez não tenham de abandonar seus lares para se dirigirem a grandes centros urbanos em busca do que comer.

O uso dos recursos naturais por estes moradores, de maneira organizada, manejada, é um caminho para a compatibilização da conservação da diversidade biológica e a manutenção da vida da população que reside na área protegida. Para tanto, o Estado precisa agir. O trabalho de criação e implantação de uma reserva extrativista é longo, como foi descrito por este estudo. Ao Estado caberia dar melhores condições de trabalho aos que lá vivem. Os recursos para a implantação 
destas unidades deveriam ser oriundos única e exclusivamente do governo brasileiro, a fim de que nossas riquezas, nossos conhecimentos tradicionais, não corressem o risco de serem exportados.

Mas, infelizmente, a sociedade brasileira ainda não pensa assim. O Programa de Áreas Protegidas da Amazônia é o principal projeto do governo que envolve as Unidades de Conservação da Amazônia. Nada contra a tentativa de encurtar o caminho entre o recurso obtido e sua aplicação nas Unidades de Conservação.

As críticas que se fazem são duas.

A primeira não é restrita ao ARPA, mas a todas as formas de contornar a burocracia institucional brasileira: é preciso acabar com ela e não contorná-la. E o primeiro passo a ser dado é a ampla reforma administrativa. Evitar-se-ia, com isto, reformas pontuais, custosas e lentas, como as seis reformas do Ministério do Meio Ambiente, ocorridas no curto período de quinze anos.

A segunda crítica que se faz em relação ao ARPA é a ampla participação externa em assuntos tão importantes para o Brasil como a biodiversidade. Neste caso, por exemplo, o Banco de Desenvolvimento Alemão supervisiona a execução do ARPA. E, ainda, no Comitê do Programa, que é instância máxima de decisão sobre seus rumos, participam seis representantes da sociedade civil, mas não há qualquer tipo de impedimento legal para que uma organização não-governamental brasileira, mas dirigida por um estrangeiro venha a participar deste Comitê como membro votante.

Enfim, a diversidade biológica não é tratada como uma questão estratégica, como uma verdadeira riqueza nacional. 
Mas, mesmo correndo o risco de ver um determinado dado científico ser exportado, sem que os direitos de propriedade intelectual sejam depositados em alguma conta brasileira, pelas entrevistas concedidas e pelos dados apresentados pelo ARPA, a contribuição externa tem sido grande, até mesmo ao nosso Baixo Juruá.

Certamente, a criação de reservas extrativistas de forma aleatória, pelo interior da Amazônia, não resolveria por si só o problema ambiental naquela região. Este trabalho partiu da hipótese de que as reservas extrativistas seriam uma boa alternativa para a conservação da diversidade biológica no Brasil. E isto foi comprovado. O fato de o Estado voltar seus olhos para uma determinada área, rica em recursos ambientais, produzir documentos, ouvir pessoas, movimentar pessoal, alocar recursos, tudo sob a ótica ambiental, contribui sim para se conservar a diversidade biológica e melhorar a condição de vida dos que lá viviam.

O Sr. João foi muito específico ao dizer que a vida dos moradores melhorou muito com mais antenas e mais geladeiras. A par dos bens de consumo, ele demonstrou bastante orgulho quando relatou a divisão dos lucros da pesca do pirarucu que ocorreu pela primeira vez na reserva, graças às licenças concedidas com o manejo. Sr. Luiz, por sua vez, também com orgulho, relatou que os moradores, atualmente, sabem que devem conservar os recursos naturais para que eles não se acabem. E esta nova consciência, segundo ele, é o resultado de todo o trabalho pela criação da reserva.

O modo de implementação da reserva não é satisfatório, pois se revela muito lento. Os conflitos atropelam esta lentidão. Contudo, um dos caminhos da conservação está certamente apontado. 


\section{ANEXO A}

1. Entrevista concedida pela Sra. Maria Goretti de Melo Pinto, por telefone, em 30 de novembro de 2007.

Lucy Lerner - Qual o seu nome completo?

- Maria Goretti de Melo Pinto

LL - Qual sua formação?

- Eu sou bióloga, tenho Mestrado em Ecologia e Doutorado em Ecologia.

LL - Você se formou em que região, em que Estado?

- Minha graduação foi na UnB em Brasília, Mestrado também e Doutorado foi no INPA em Manaus.

LL - Você ingressou no IBAMA no concurso de que ano?

$-2005$.

LL - O concurso já era regionalizado? Você escolheu ir para a RESEX do Baixo Juruá?

- Não, me escolheram. O concurso foi estadual. O concurso tinha uma escolha, mas era por ordem de classificação. Tinham as vagas definidas para os locais, as unidades de conservação, e dentre aquelas unidades, de acordo com a 
ordem de classificação a pessoa poderia colocar suas prioridades. Como, na primeira chamada, eu fui a última colocada, então, obviamente, a minha ordem de prioridade não foi respeitada. Eu não tive opção.

LL - E, então, você mudou-se para Tefé, para o Escritório Regional do IBAMA?

- Sim, eu me mudei com meu marido e minha filha.

LL - Quantas pessoas trabalham na RESEX?

- Eu. Agora foi chamada na sétima chamada, mais uma Analista.

LL - Quais suas atividades como chefe da RESEX? E qual seria sua principal atividade como chefe da RESEX?

- Tudo. Eu tenho que responder sobre absolutamente tudo. Só que as prioridades que elejo são a elaboração do Plano de Manejo e a instalação do Conselho Deliberativo que a gente está trabalhando mais em cima disto. Aí é claro, tem a questão da fiscalização, as emergências que vão atropelando, que aparecem que a gente tem que resolver.

LL - Vocês respondem muita demanda de Ministério Público?

- Não, nenhuma. Ministério Público nem sabe que existe aquela área. Na verdade, hoje o que mais me consome tempo é a questão administrativa. Prestação de contas, compra de material, aluguel de embarcação, compra de combustível, especificação de equipamento, estas coisas.

LL - Quais suas maiores dificuldades para o desempenho de suas funções?

- Basicamente o tempo e a questão administrativa mesmo que não é a minha área. Claro que como funcionário publico todo mundo acaba tendo que desenvolver, mas no nosso caso esta questão é maior ainda. Envolve mais ainda porque a unidade de conservação é uma unidade avançada, uma unidade meio autônoma. Então diretamente a gente se envolve mais com isto, do que por exemplo, do que quem trabalha nos escritórios. É isto é a administração mesmo. A dificuldade é o tempo, porque consome muito tempo e o fato de não ser a minha área, então eu gasto mais tempo ainda. 
LL - Você teve algum tipo de preparação para isto? O IBAMA te deu alguma preparação para esta gestão, pelo fato de você ser uma bióloga?

- Na verdade, como eu fiz Mestrado e Doutorado administrando projetos, então, eu tinha uma noção. Aqui a coisa é mais, volume, recurso é maior as responsabilidades são maiores. Uma noção eu já tinha em administração de projetos. Na verdade, o órgão não me deu capacitação não. Mas a gente tem o Programa ARPA e na verdade o dinheiro vem todo do ARPA hoje, então o ARPA dá alguma capacitação para nós. Oferece cursos.

LL - Voltando à questão do Plano de Manejo da RESEX, ele está a cargo de que instituição?

- Quando eu entrei em 2005, ele já havia iniciado. O processo começou com o Walter em 2003, ele deu o pontapé inicial, mas no começo não tinha verba. Ele correu atrás de projeto, de tudo, mas a verba era muito pequena. Depois com entrada do ARPA é que deu um gás para a questão. E o ARPA começou basicamente em 2005. Então, quando eu entrei, o Paulo já tinha escolhido trabalhar com vários consultores, um consultor para cada área. Essas pessoas já tinham iniciado o trabalho quando eu entrei. Na verdade o que eu faço hoje é trabalhar com esses quinze consultores hoje, a maioria já entregou os diagnósticos, está faltando só um e agora a a gente acabou de contratar um consultor para juntar todo o trabalho. Elaborar o documento final, discutir as regras de convivência das comunidades, junto com a gente, é claro e fazer esta compilação e elaborar este documento final para a gente encaminhar para a aprovação, discussão e tudo mais. E eu coordeno.

LL - Quais os meios financeiros que você dispõe para exercer suas funções?

- Como falei o dinheiro vem do ARPA. O ARPA significa Áreas Protegidas da Amazônia. É um programa de doação internacional, financiado pelo Banco Mundial, KfW, que é o Banco Alemão, WWF - Brasil. Este dinheiro vem através de doação ao Ministério do Meio Ambiente. É uma forma inovadora porque o governo não passa pelo governo: o dinheiro vem direto dos doadores para o FUNBIO, que é Fundo Brasileiro para a Biodiversidade, seria uma ONG. Foi escolhida no início do programa pelos doadores, e esta ONG administra os recursos. E este recurso passa então direto dos doadores para o FUNBIO que repassa para a gente, os gestores diretamente. Então, a parte de coordenação, a parte técnica tudo, o Programa tem a Coordenação Técnica que é a UCD Unidade Coordenadora do programa que é dentro do MMA. Tem o braço financeiro que é o FUNBIO, que tem sede no Rio de Janeiro e tem o ponto focal que fica na Diretoria em Brasília e temos nós. Nós trabalhamos com conta vinculada, é aquele recurso que precisamos no dia a dia. Eles repassam 
para uma conta, que nós movimentamos essa conta. Compra de equipamentos estas coisas, nós especificamos e o FUNBIO faz as licitações e compra.

LL - Mas você tem um orçamento mensal previsto?

- Nós temos um orçamento anual, então eles definem. Hoje, depois do programa já ter passado por várias reformulações e aperfeiçoamentos, hoje eles definem um teto anual, sendo que há dois meses atrás eles definiram o nosso teto para o ano que vem. São valores baseados em inúmeras questões como tamanho, andamento de programa, diversos fatores que determinam este teto. O ARPA não financia tudo e qualquer coisa dentro da unidade. Ele prioriza assuntos do programa que é planos de manejos, conselhos deliberativos para unidades de uso sustentável, fiscalização, operacionalização da unidade, que é manutenção e questões administrativas. Dentro deste teto nós fazemos uma programação e encaminha. Inclusive nesta semana nós estamos na fase de adequar dentro do ponto focal, ver se está tudo certinho. Aí passa pela aprovação do ponto focal, que passa para aprovação da UCB, que também aprovando, então, encaminha ao FUNBIO, e aí os doadores aprovam então a gente tem isso aí. É dinheiro que existe. Não é nada virtual, tipo do governo que depende de outro não. É dinheiro que existe. Eu defini que há uma programação trimestral de desembolso, mas não é uma coisa super rígida, se tem algum problema não conseguiu executar naquela data o dinheiro não vai embora. Ela está lá. A gente vai solicitando o dinheiro na medida do necessário.

- Além desta verba a unidade recebe alguma verba do MMA ou do IBAMA?

- Como a gente já tem este do ARPA, já tem dois anos que a unidade não recebe nada do IBAMA e nem solicita. Já há dinheiro suficiente. Em face da “euquipe”, há uma capacidade extremamente limitada de gasto, de conseguir gastar. Além disto dinheiro do IBAMA é normalmente mais difícil de gastar.

Há uma diferença absurda entre as unidades que tem ARPA e que as que não tem. Não são todas as unidades da Amazônia que tem ARPA, tem critérios para entrar no ARPA.

LL - Quanto às comunidades da RESEX, você tem idéia de quantas pessoas moram na região atualmente?

- Aproximadamente 800. 
LL - Quais são as lideranças da região?

- A grande associação é a Associação do Trabalhadores Rurais de Juruá ASTRUJ. É a associação que representa os moradores. Essa associação foi criada para lutar pela criação da RESEX, então representando os moradores da então proposta da RESEX. E ela tem suas lideranças, o presidente, o vice-presidente, tem todo o corpo da associação. Em cada comunidade, isso já é uma organização que existe bem antes da criação da RESEX, um modelo amazônico que foi incentivado pelo MEB - Movimentos Eclesiásticos de Base, que é em relação a Igreja Católica, teologia da libertação, esse movimento passou nessas comunidades organizando as comunidades, na região Amazônica. Então, em quase todos os municípios que você vai, por mais distante que seja, se é uma comunidade com tamanho mínimo, que pode ser chamado de comunidade, eles estão de alguma forma organizados. Eles têm nome a comunidade, eles tem ata de criação, registrado em cartório, como comunidade. E a comunidade sempre vai ter um presidente, um vice, um secretário, aquela coisa toda de uma chapa. Nem sempre funciona, o que funciona mais é o presidente. O presidente e o vice são reconhecidos como liderança dentro da comunidade. Eles elegem a cada um ano ou dois anos. Normalmente a cada dois anos eles elegem um presidente. E eles reconhecem esse presidente como liderança, lideranças que vão lutar junto à prefeitura local, junto ao Estado qualquer convocação que eles tenham. Isto de forma geral. Na RESEX não é diferente é assim mesmo. Algumas comunidades são mais organizadas outras são menos, mas sempre tem o presidente que é uma liderança.

LL - Quais os maiores conflitos que existem dentro da RESEX?

- Hoje o ciclo da madeira não está mais no Juruá, pelo menos no Baixo, Médio Juruá. Hoje o conflito maior é em relação à pesca. O recurso pesqueiro. É um conflito com pessoas de fora, de outras comunidades, com moradores da cidade, é conflito. Pessoas querendo pescar, outras não querendo deixar pescar, umas querendo pescar para subsistência, outras comercialmente.

Aqui antes da RESEX ser criada, aqui na região do Médio, Alto Solimões, já havia as Portarias de proteção de Lago, foi daí que tudo começou. As pessoas já tinham essa briga, principalmente as comunidades que moravam que usavam os lagos para a pesca de subsistência, alimentação e vinham aqueles barcos pesqueiros de outros lugares, principalmente das capitais Manaus, Belém, e chegavam para pescar nestes lagos e carregavam tudo. Então já tinha este movimento de pedir ao IBAMA, na época SUDEPE, portarias de proteção dos lagos para que as pessoas fossem proibidas de pescar. Tem aquela questão, o recurso pesqueiro é bem da União, ou seja, de todos, então todo mundo pode pescar, desde que seja dentro da lei, esteja dentro das regras estipuladas por lei, qualquer um pode pescar em qualquer 
lugar. Os lagos são bens da União. Os lagos, os rios são bens da União, então isto cria muito conflito. Muitas vezes vem gente, vem barcos pesqueiros de fora para pescar nestas áreas, e cada vez eles vão mais longe porque vai exaurindo os recursos das áreas mais perto, então eles vão buscar o recurso mais longe. Quem mora naquelas áreas acaba sendo prejudicado, porque vai diminuir o recurso para a comunidade.

LL - E eles recorrem ao IBAMA para resolver esta questão? O que eles pedem?

- Na RESEX, antes de ser criada a RESEX já tinha algumas portarias de proteção de lago, porque lá já tinham conflitos, porque é uma área que não tem muitos lagos na RESEX em si. Do outro lado da RESEX tem bastante lago. A gente tem aqui uma figura muito comum que é do tal do "dono de lago". É um sujeito que pode ter sido dono de seringal, ou não e como acabou o ciclo da borracha, ele tem o título da terra ou não, simplesmente pode ser um posseiro, pode ser grileiro ou sei lá mais o que, ele toma conta da área e também toma conta do lago. Ele diz que o lago é dele porque a área é dele. Então ele só deixa pescar quem ele quer, ele cobra porcentagem para um barco entrar e pescar ou das comunidades. É uma situação bem complexa. Assim como o dono de lago oficialmente não existe, você também não cercear a utilização para uma pessoa ou outra. Não pode dizer assim: só gente daqui pode utilizar. Isto não existe, a lei não permite. Dentro de uma RESEX você pode definir as regras, fora de uma unidade de conservação não, porque é bem da União. Então existe a figura do acordo de pesca, que é uma regulamentação em que você pode restringir os apetrechos de pesca, a temporada de pesca, as espécies de pesca. Você não pode restringir pessoas, nem localidades de onde elas vêm. Isto já ajuda um pouco, mas ainda não resolve esta questão. E o acordo de pesca ainda é uma situação nova, a IN é de 2002 se não me engano, que criou este instrumento jurídico do acordo de pesca. É complexo de realizar um acordo de pesca. É acordo mesmo você tem que ter milhões de reuniões, chegar a um acordo entre todos os usuários, seja o comerciante. Esta é uma figura jurídica para fora da RESEX, para tentar resolver estes conflitos. Outra forma, antes de existirem estes acordos de pesca eram as Portarias, então as comunidades pediam ao IBAMA para fazerem Portarias proibindo a pesca. Existem ainda várias destas Portarias. Hoje o IBAMA não tem mais feito Portaria, não é mais a política atual. Poucas têm saído, mas existem umas em validade, dizendo assim: este lago é proibido para pesca, ou este lago é proibido para pesca comercial, este é um lago de manutenção, ou seja, só é permitida a pesca de subsistência, não pode entrar a pesca comercial. Isto sempre as comunidades procurando o IBAMA para fazer isto.

Com a criação da RESEX você pode trabalhar isto melhor, como é unidade de conservação, você pode de fato proibir. Tem todo um leque aberto de opções, pode fazer o acordo que quiser. Como na RESEX em si, a maior parte é área de terra 
firme, tem poucos lagos, então, basicamente, os lagos são utilizados para manutenção mesmo. Inclusive eles guardam os lagos, não deixam ninguém pescar naquele lago, porque eles entendem que aquele lago pode ser uma área de procriação, que vem abastecer os outros lagos. Então, deixa um repousando e usa outros. Podem trocar também. Daí a dois anos eles deixam de usar esse usam o outro. Existe essa consciência de conservação.

LL - Goretti, consta do Levantamento Sócio Ambiental feito em 1998 que a principal atividade desenvolvida pelos moradores de Juruá naquela época era a agricultura e isto era uma preocupação para o IBAMA. Este quadro mudou?

- Não. Continua. A produção da mandioca é a principal atividade. A farinha é a moeda principal. Às vezes vendem, às vezes trocam.

LL - O extrativismo vegetal é uma atividade desenvolvida na região?

- Hoje não. O ciclo da borracha desapareceu na região acabou no Baixo Juruá. No Alto Juruá existe ainda. Existe um mínimo para a subsistência, quando tem castanha, por exemplo. Não é todo lugar que tem castanha. Castanheira é uma espécie que vive agrupada, em alguns lugares tem castanhal. Lá na RESEX do Baixo Juruá não é uma área, não é um grande produtor de castanha, mas tem. Então, na época de castanha, eles coletam para subsistência e vendem o que sobrou. Basicamente eles vendem o excedente. Óleos. Óleo de copaíba, de andiroba, eles fazem para o consumo. E eventualmente, o excedente eles vendem. Não é nada organizado, não é que eles tenham uma produção mesmo. A única coisa que eles têm a produção certa é a farinha. Peixe também eles vendem alguma coisa. Por exemplo, este ano a gente começou o mês do pirarucu na área, então eles obtiveram a licença para poder pescar um número $\mathrm{x}$ de pirarucu e a pesca foi comunitária então eles venderam os pirarucus e dividiram comunitariamente quem trabalhou na guarda do lago e na pesca do pirarucu.

\section{Entrevista concedida pelo Sr. Walter Behr, por telefone, em 04 de dezembro de 2007.}

Lucy Lerner - Qual sua formação acadêmica?

- Minha formação é Administração de Empresas, sou formado pela Fundação Getúlio Vargas. 
LL - Em que ano você entrou no IBAMA?

- Novembro de 2002.

LL - Por que você foi para RESEX do baixo Juruá, como se deu esta escolha por aquele lugar?

- O concurso não era regionalizado ainda, e eu acabei caindo na RESEX.

LL - Mas, por que a RESEX? Você foi escolhido ou você a escolheu?

- Na verdade, a minha idéia principal era Parque Nacional, em algum lugar na região da Amazônia. Mas, como eu sabia que não havia passado no concurso nas primeiras colocações eu optei por algumas áreas na Amazônia que fossem bem distantes e que fossem unidades de conservação também. Acabei atingindo algo que eu queria em tese que era uma unidade de conservação, que foi a RESEX, em um lugar bastante isolado na Amazônia, para ter uma experiência de fato com a Amazônia preservada, profunda, não com a parte, digamos, de conflito, que eu, realmente, não estava a fim de ir para estas áreas.

LL - Você não optou por uma unidade de conservação que não fosse de proteção integral?

- Se eu pudesse escolher até teria escolhido. No fundo, depois, foi muito rico para mim ter tido a vivência em uma unidade de conservação de uso sustentável. Riquíssimo porque eu tinha um certo preconceito com esta categoria, mas era muito por desconhecimento, por diversos argumentos que são colocados na teoria que quando você vivencia mesmo a realidade Amazônica, principalmente, a categoria de RESEX é realmente muito apropriada. Mudou bastante a forma de eu julgar e analisar a questão das reservas de desenvolvimento sustentável que eu acho bastante viável na realidade Amazônica e em outros lugares também e hoje tenho uma posição muito mais neutra a isto, não é. Eu sabia também que seria uma boa porta de entrada para que eu viesse a trabalhar em uma unidade de proteção integral como realmente aconteceu, então foi uma forma muito boa de entrada no IBAMA: ter uma experiência na Amazônia com uma unidade de uso sustentável e depois trabalhar numa proteção integral, como aquilo que eu sempre quis nesta região Sudeste.

LL - Quantas pessoas trabalhavam na RESEX quando você chegou para trabalhar? 
- A RESEX havia sido recém-criada. Ela tinha sido criada em 2001 e eu cheguei em 2002, ou seja, não tinha nenhuma estrutura em Juruá que é a chamada cidade sede. A presença do Estado começou com a minha chegada, sem nenhuma estrutura. Toda a estrutura começou a ser montada do zero desde a construção do escritório com alojamento, busca de equipamentos, elaboração de projetos para melhorar a condição, aquisição de computador, telefone. Tudo isto foi absolutamente do zero.

LL - Você chegou em Juruá, então?

- Exatamente. A RESEX é criada em torno da cidade, ela está praticamente cercada pela RESEX. Na verdade, é um modelo interessante porque de certa forma limita o crescimento da cidade. A RESEX vai, sem dúvida, ser um fator de contenção a um crescimento desordenado, que é o que acontece em geral, nas cidadezinhas que vão tendo crescimento populacional muito grande, e vai avançando sem limites. A RESEX vai obrigar a ter um planejamento maior na área que não é dentro da RESEX. Achei bem interessante este formato da RESEX aí.

LL - Quantas pessoas, não servidoras do IBAMA, estavam envolvidas no seu trabalho, e de que forma?

- O mais importante é que como a RESEX foi uma reivindicação local, o trabalho de um padre que há muitos anos atrás, visitando outras regiões em que existiam RESEX acabou trazendo essa informação lá na região, a região é composta por ex-seringueiros que chegaram na região na década de 40 e 50 e por lá ficaram, os famosos soldados da borracha, incentivados pelo governo na época e depois largados a própria sorte formaram algumas ilhas na Amazônia que depois viraram cidades e uma delas foi Juruá. Então, motivadas por este padre, fizeram um movimento para que fosse criada lá na região uma RESEX também. A vantagem é que você tem uma unidade de conservação que é reivindicação local, então, a presença do governo é muito bem vinda. É um reforço àquela reivindicação daquela comunidade. Então, eu tive muito apoio neste sentido: tinha Presidente da Associação, os Diretores, membros da comunidade, construindo a sede. A Prefeitura dando apoio, então, houve um apoio muito grande para que se estabelecesse uma base lá e que se iniciasse um trabalho mais organizado e com a presença do Estado. Formar o Conselho Deliberativo com os representantes das comunidades, representantes da Prefeitura, de outras instituições. Aí começou um dinamismo diferente porque o Estado estava então legitimando o domínio das comunidades naquela área, que teoricamente era de domínio de seringalistas e pessoas que exploravam e ainda exploram os recursos. Como era tudo terra da União, os maiorais sempre dominaram. Com a RESEX, pela primeira vez as comunidades tiveram uma autorização do Estado de utilizar aquela área. Foi uma transformação muito grande na vida daquelas pessoas. Só que quem 
chegou para, vamos dizer assim, dar legitimidade a isso é a chegada do Estado, com o IBAMA, com a minha vinda lá, com o concurso, e depois de oito meses chegou o Paulo, que foi o outro Analista Ambiental que ficou comigo por seis meses lá. Com isto, fizemos valer esta nova realidade.

LL - Então, depois de você chegou um outro Analista Ambiental?

- Sim, o Paulo chegou oito meses depois, ficou comigo durante aproximadamente seis meses, e depois nós revezávamos a permanência na RESEX. Com isto, ficamos com permanência constante na RESX por pelo menos 2 anos.

LL - Você tem idéia de quantas pessoas residiam nas comunidades que integravam a RESEX?

- Eram treze comunidades, algumas mais envolvidas, outras menos. O movimento todo começou na comunidade de Botafogo, que era onde morava o Presidente da Associação. Então, lá começou a organização maior e acabou envolvendo as áreas, que é uma área grande, não tão grande para a Amazônia, mas mesmo assim uma área grande. O deslocamento para se chegar nestas treze comunidades é bastante longínquo. Várias comunidades se envolveram, outras não, eram arredias, porque tinham gado e não queriam nem saber de RESEX, porque a RESEX não incentiva a criação a pecuária.

LL - Qual a principal atividade econômica desenvolvida pelos moradores das comunidades?

- Produção de farinha. Na comunidade de Botafogo tinha uma produção de andiroba, não muito bem organizado, mas eles fabricavam óleo. Quer dizer, tem este potencial lá na área de Botafogo.

LL - Qual a dificuldade encontrada para desenvolver esta atividade? O IBAMA, de alguma forma, auxiliou a enfrentar esta dificuldade?

- A busca pelo Estado se deu para garantir o uso daquele recurso que era constantemente invadido. Eles queriam se proteger dos maiorais, capitalistas, que pescavam para vender longe em Tefé, Manaus, e também se proteger daqueles que vinham de longe de Manaus, Manacapuru para pescar lá na região, ou seja roubar o recurso deles. 
LL - O principal conflito que você aponta é a pesca?

- É a pesca. Como tem muitos lagos e os lagos são muito ricos, então, eram constantemente invadidos e todo este recurso era roubado. Isso é comum na Amazônia. O que acontece, para abastecer o mercado de 2 milhões de pessoas em Manaus, você precisa ter uma enorme frota de barcos, que invade todos os lugares para levar os recursos para Manaus. Quando eu cheguei lá, por exemplo, tinha sido recém capturada uma balsa com 15 mil tracajás, que é uma tartaruga menor, para levar para Manaus. Então, é um ataque ao recurso que é uma coisa inacreditável. A questão da insustentabilidade surge porque o recurso é levado embora. O recurso consumido na região ele é plenamente sustentável, ainda mais se for feito de uma forma organizada. Este era um dos objetivos: você ter uma manejo de lago, onde você um período em que aquele lago se recupera, o recurso se recupera, enquanto no outro você pesca uma certa quantidade. E eles têm a condição de se recuperar. Organizar, enfim, esta pesca, de forma que sempre haja o recurso disponível, este era o desafio na questão da pesca e ao mesmo tempo dar outras alternativas. Buscar a possibilidade de colheita e produção do óleo de andiroba, por exemplo, como já feito na RESEX do Médio Juruá, de forma vitoriosa com a Natura, que compra aqueles produtos. Sendo uma RESEX vizinha poderia estender o processo e incluir a RESEX do Baixo Juruá.

LL - Quais eram suas funções como chefe da RESEX?

- Meu dia a dia no início, superando problemas básicos de onde ficar, porque é um lugar isolado, não tem hotel, não tem alojamento, enfim, eu tinha que arrumar estas coisas. Bom, então, era fazer contatos, primeiro com o pessoal da associação que ajudou a criar a RESEX e depois com os diferentes órgãos estaduais, do governo, prefeituras, secretarias, promotor, todas as instâncias, me apresentando e procurando apoio para este trabalho na RESEX e conhecendo as comunidades. Conversando com as lideranças, tentando planejar um pouco o trabalho. Chegou-se ao consenso de que a primeira questão fundamental era ter uma base de trabalho, se não, não dava para fazer nada. Não dava para fazer um projeto, não dava para fazer uma reunião, enfim, era organizar esta base, e uma vez isto feito organizar o Conselho Deliberativo, fazer reunião com este Conselho, reunião preparatória para que ele fosse criado, e isto já deu um dinamismo. Porque para a formação tinha que visitar todas as comunidades, convidar os representantes para as diversas reuniões e aí foi aos poucos tendo um dinamismo e, obviamente, atendendo a uma série de reivindicações, de problemas, de invasão, como lidar, tirar as dúvidas, muitas comunidades e muitas pessoas mesmo na cidade tinham muitas dúvidas de como era o funcionamento de uma RESEX, a apreensão do que se poderia e o que não se poderia. Então, foi todo um trabalho de formação, de envolvimento, toda essa fase 
inicial e ao mesmo tempo tentar junto a nossa representação em Tefé e em Manaus melhores condições de trabalho. Isto também foi uma luta constante.

LL - Quais os meios financeiros que você tinha para exercer o seu trabalho?

- Praticamente não tinha. Depois de vários meses eu recebi um suprimento que era uma forma de algum apoio para gasto emergencial e era bem simbólico, consegui trazer um computador. Começou a ter recursos quando começamos a ter projetos aprovados: dois projetos no Fundo Nacional do Meio Ambiente, tivemos recursos do ARPA e de várias outras fontes, de projetos encaminhados pela RESEX que eram em geral, prioritários, porque a RESEX está dentro das unidades do ARPA, da região central da Amazônia, acaba sendo prioritária.

LL - Mas, do IBAMA não havia nenhum recurso para a RESEX?

- Muito pouco. Havia um recurso que vinha para o CNPT em Manaus. Sei lá, acho que vinha $\mathrm{R} \$ 20.000,00$ semestralmente e era dividido por todas as RESEX e acabava o dinheiro. Acabava vindo $\mathrm{R} \$ 2.000,00$ ou $\mathrm{R} \$ 3.000,00$ por semestre, mas era muito simbólico para ser utilizado como suprimento, aquisição de mantimento para viagem para as comunidades, mas muito simbólico. Depois de alguns meses começou a pagar a conta de telefone que antes era pela Associação. O apoio era muito pequeno, o que fez realmente a diferença foram os projetos.

LL - A base construída foi financiada pelos projetos?

- A base foram as comunidades mesmo e a Prefeitura. As comunidades retiram madeira para uso próprio, então fizeram as tábuas, construíram o escritório com o alojamento, e a Prefeitura ajudou na parte da alvenaria e construiu os banheiros. Ficou uma base com dois alojamentos, uma base com o mínimo necessário, um escritório com uma sala para encontros. Ficou uma base pequena, mas bem estruturada. Parece que veio a ser adquirida com recursos do ARPA, adquiriram para o IBAMA depois aquela área. Foi comprada depois uma outra para construir uma sede da Associação. 
3. Entrevista concedida pelo Sr. João da Silva Ferreira, por telefone, em 31 de dezembro de 2007.

Lucy Lerner - Como é o nome completo do senhor?

- João da Silva Ferreira

LL - Quantos anos o senhor tem?

- Tenho 47 anos.

LL - Qual o seu cargo na Associação?

- Eu sou Presidente desde 2006.

LL - O senhor vive de que S. João?

- A gente vive da farinha da pesca. A comunidade faz farinha.

LL - O senhor faz a farinha também?

- Faço sim.

LL - O senhor vende a farinha que faz ou só consome?

- Olha, no momento nós estamos só consumindo, quando tem a gente vende, né. A gente vende até quando dá para vender aí quando dá só para o consumo a gente pára. No momento a gente tá só para o consumo. Inclusive eu terminei de chegar, eu levei, tem a feira do índio em Manaus, todos os anos tem, aí eu fui levar a farinha da comunidade. É uma das farinhas mais vendável por aqui é da comunidade Antonina. Tem a farinha de várias comunidades mas a melhor mesmo é da comunidade Antonina.

LL - Sr. João, o que é o Regatão que eu li no Levantamento Sócio Econômico do IBAMA? 
- Regatão é aquele barco que invés de loja na cidade faz no barco. Faz a lojinha no barco e sai vendendo nas comunidades, nas beiradas, para as pessoas mais difíceis. Vai parando de comunidade em comunidade e vendendo e comprando. Só que agora é difícil aparecer o Regatão, mas de primeiro tinha bastante, agora é mais difícil de encontrar. São pessoas vindas de outros municípios, outras cidades, passam vendendo.

LL - Sr. João, mudando um pouco de assunto, eu conversei bastante com a Goretti, antes de conversar com o senhor e ela me falou sobre a questão do "dono do lago". Existem donos do lago na área da RESEX?

- Tem não. Na área da reserva não.

LL - Tinha antes do IBAMA?

- Na área da reserva quase não aconteceu isso. Aconteceu muito pouco. Mas fora dela ainda existe. As pessoas que são donas do lago e arrendam o lago, o peixeiro, a pesca é irregular, sempre acontece.

LL - Quanto a isto a RESEX não ajudou em nada?

- Continua na mesma.

LL - Quanto a saúde dos habitantes de Juruá, a vida de vocês mudou com a criação da RESEX? O Posto de saúde melhorou, tem mais médico?

- Neste sentido está quase na mesma. Na área da reserva tem três postos, mas está confiando mais mesmo em um, os outros dois não estão funcionando.

LL - Mas tem médico ou só enfermeiro?

- Só os agentes que é formado pelo município.

LL - Quando acontece algo grave, vocês vão para onde? 
- Vem todos para Juruá. Eles passam o rádio, eles mandam o recado, a gente vai pegar na comunidade e leva até a sede do município. E aqui só tem dois médicos: aqui tem um que opera e outro que faz consultas.

LL - E as escolas, Sr. João mudaram com a criação da RESEX?

- Sobre as escolas melhorou mais um pouco.

LL - Por que?

- Porque tem mais professores.

LL - Voltando um pouco para o trabalho da ASTRUJ, no momento qual a principal briga de vocês? O que vocês estão brigando para conseguir na ASTRUJ?

- No momento meu é só o Plano de Manejo que nós estamos lutando. Por enquanto só isto mesmo.

LL - E a Goretti vai a Juruá quantas vezes no mês?

- Ela demora a vir aqui, um mês, 15 dias. Só quando tem algum trabalho assim que ela vem fazer. Dia desses, ela veio porque teve uma invasão de índios na área da reserva e aí ela veio, para a gente resolver. Mas, graças a Deus a gente resolveu isto.

LL - Mas, o que ocorreu com os índios?

- A Goretti entrou em contato com a FUNAI, a FUNAI veio aqui e conseguiu tirar eles. Eles entraram para ficar e não queriam sair não. Aí foi negociado e conseguiu tirar eles.

LL - Chegou e ter desmatamento, S. João?

- Não, nós fomos lá e tentou conversar com eles e pediu para eles não desmatar enquanto não resolvesse e parece que eles não desmataram. Desmataram só um pouquinho que já era uma área de capoeira, não teve muito problema não. 
LL - O senhor nasceu em Juruá?

- Eu nasci em uma localidade chamada Moraia Nova , bem pertinho aqui, quinze minutos. Fui para Botafogo, cheguei lá com dois anos e saí de lá com uns trinta e um anos acho. Acho que passei lá uma Bse de trinta anos lá. E aí vim para a cidade por causa dos meus filhos, que precisava de estudar. E aí estou aqui todos estes anos.

LL - E faz a mesma coisa que o senhor fazia em Botafogo?

- A mesma coisa. Aliás eu planto lá, a gente vai lá passa uma semana.

LL - O senhor tem sua casa lá ainda?

- Tenho sim senhora.

LL - Quantos filhos o senhor tem?

- Cinco.

LL - Eles estudaram S. João?

- Estudaram.

LL - Moram com o senhor?

- Moram três comigo. Uma está em Manaus e outra mora aqui pertinho de mim, ao redor, uma casa pertinho da outra. Ela casou com um PM e foram morar em Manaus.

LL - Senhor João, com a criação da RESEX teve mais ou menos desmatamento?

- Teve menos eu acho. As pessoas a gente sempre aconselha a desmatar na capoeira a aproveitar mais onde já está desmatado.

LL - E quanto à pesca, a vida melhorou ou piorou com a criação da reserva? 
- Melhorou porque agora a gente tem mais o apoio. Quando não era reserva a gente não podia fazer nada quando o invasor entrava. Agora tem os agentes ambientais, e mesmo a gente começou a tirar o pirarucu que ninguém podia tirar. Agora a gente já começou a tirar para vender. Porque agora, durante o manejo de pesca, o pirarucu, o tambaqui, matuxã, nós produzimos na reserva na base de R\$ 100.000,00, divididos para as comunidades. Aí melhorou porque não é mais para uma pessoa só que é o peixeiro, que é só ele mesmo que ganha. Assim a comunidade inteira ganha.

LL - Quando começou o manejo da pesca?

- A autorização foi com a Goretti, mas o incentivo foi com o Paulo. Quando ele saiu nós já ficamos até guardando o lago. Inclusive foi ele quem conseguiu dar o negócio do combustível.

LL - E a vida dos moradores da comunidade, S. João, melhorou ou piorou com a reserva?

- Ah, melhorou. Hoje eles têm antena, alguns tem geladeira.

LL - Mas o que isto tem a ver com a reserva S. João?

- É que com a reserva eles olharam mais para a gente e o dinheiro começou a rolar mais na região.

LL - A casa do IBAMA está fechada, S. João?

- Não porque é onde funciona a ASTRUJ. O IBAMA ainda não tem sede aqui. Tem projeto para fazer um. A gente ia doar para o IBAMA, mas depois que a Goretti entrou ela disse que não precisa mais doar que ia fazer um.

LL - S. João, esqueci de perguntar uma coisa, como vocês vão a Tefé? Só tem o barco?

- O meio mais certo é de barco. Tem uma linha aérea pequena, uma empresa pequena. Às vezes a Goretti empresta vôo, quando tem vôo paga a passagem, mas é mais difícil. O acesso é mais de barco. Tem um barco da linha de Recreio, que sai acho que três vezes na semana. Dá 40 horas subindo. 


\section{Entrevista concedida pelo Sr. Luiz Rocha Maciel, por telefone, em 03 de janeiro de 2007.}

- Me chamo Luiz Rocha Maciel, sou acadêmico de Engenharia Florestal, da Universidade do Estado da Amazônia, UEA, eu sou aqui do município de Juruá, só estou longe do local de origem pelo fato de estar na Universidade. Também sou técnico florestal, e técnico de pesca, já fiz alguns trabalhos na reserva na parte de acessória , inventários florestais e alguns mais outros serviços que a gente vem desenvolvendo ao longo da criação da reserva.

Lucy Lerner - Você nasceu ai em Juruá, ou em alguma outra comunidade?

- Eu nasci numa comunidade, no município de Juruá, no interior do estado. Eu nasci numa comunidade chamada Pupunha a mais ou menos $200 \mathrm{~km}$. longe da sede do município.

LL - Quantos anos você tem?

- Eu tenho 27 anos.

LL - Você morou em Pupunha até que idade?

- Eu morei em Pupunha até uns 12 anos mais ou menos, ou um pouco mais acho que uns 15 anos. Aí eu me mudei pra sede do município, foi onde eu comecei a estudar.

LL - Aí era o colegial?

- Quando eu me mudei para a sede eu aprendi a estudar, a ler e escrever em casa, sem professor. Quando chegava uma pessoa, o meu pai pedia que me passasse alguma lição e foi assim que eu aprendi. Quando eu chequei na cidade eu já sabia ler e escrever, somar, dividir, multiplicar, as quatro operações básicas de matemática. Eu entrei já assim na segunda ou $3^{\text {a }}$ série quando eu me matriculei, eu não passei por aquele período de alfabetização, fiz uma provinha na escola e já entrei na $3^{\mathrm{a}}$ série, não tive que ser alfabetizado, porque eu já tinha um mínimo de conhecimento.

LL -Aí você estudou até o colegial? 
Eu fiz até o ensino fundamental, eu fiz o ensino fundamental em Juruá . Quando eu estava assim, na sexta ou sétima série, eu prestava serviço, eu era de menor, mas assim mesmo eu entrei na Secretária de produção do município de Juruá e eu fui prestar serviço num órgão chamado Instituto de Desenvolvimento Agropecuário do Estado do Amazonas - IDAM, e, daí despertou a curiosidade pelo interesse ambiental. Aonde eu morava, onde eu nasci, eu via a degradação, as pessoas, os infratores cometendo $\mathrm{n}$.infrações que não seriam punidos por ninguém, então, aquilo me chocava muito.

LL - Isto em que ano?

- Isso seria assim em 80 e poucos. Noventa mais ou menos, já seria noventa, né, oitenta e oito para noventa, noventa e um mais ou menos, então me chocava muito e eu apenas assistia. Meu pai fazia muito relato que da época que chegou aqui, a família dele veio do Ceará, ele me fazia relatos do que tinha e para o que tinha no momento, então, já tinha uma mudança muito grande, né. Coisas que ele me contava que tinha em abundância, em 90 já tinha poucos, imagine agora. Então, foi daí que despertou a curiosidade de eu me interessar pela questão ambiental. Aí eu terminei, fui terminando meu ensino fundamental aqui no Juruá e eu tive conhecimento através de um colega, que tinha se formado em técnico em agropecuária em Manaus, na Escola Agrotécnica Federal de Manaus. Aí, quando eu terminei a oitava série, eu fiz o processo seletivo, um mini vestibular, eu passei, e fui para Manaus estudar, foi aonde eu terminei o meu ensino médio, juntamente com o curso de pesca.

\section{LL - Você foi para Manaus em que ano?}

- Eu saí em 2001. Neste processo estava sendo criado a RESEX. Os meninos eu não tinha nenhum contato diretamente com os meninos da RESEX, mas eu já sabia que estava sendo criada através de um professor que era lá da escola.

- Você acha que a conservação da área de reserva mudou com a criação da reserva?

- Com certeza. Vou dar exemplo: em 2000 ou 2001, quando eu estava em Juruá, sempre eu saía para pescar no final de semana , quando eu tinha folga. Eu saia para pescar onde hoje é reserva, né, então você tinha muita dificuldade pra capturar mesmo pescado pequeno, e hoje a gente consegue ver isso com facilidade. É tanto que foi retirado aí, 15 toneladas de pescado este ano, graças a Deus e tem muito mais pra ser retirado no ano que vem, então a recuperação está sendo muita rápida, graças a Deus, com o empenho dos meninos da associação, que colocam pessoas, os próprios moradores através de cursos de capacitação de agente ambiental em parceria com o IBAMA. Treinar essas pessoas para que façam monitoramento nos 
locais apropriados para que, não para que a gente consiga inibir $100 \%$, porque a área é ...tem invasões que vem de outros municípios, daqui mesmo da sede do município tem pessoas que são contra, e, vão lá invadir, perturbar, inventam fofocas, mandam cartas pra fora pedindo anulação da reserva.

LL - Pedindo anulação da reserva?

- Olha, só pra senhora ter uma idéia: Voltando um pouquinho, em 2005, quando eu estive aqui, teve uma noite que eu não dormi aqui, com o presidente da associação, fazendo uma carta para a gente mandar pra ministra, porque o que aconteceu: Um bando de vereadores aqui fizeram um abaixo assinado para pedir a anulação da RESEX .Então o que acontece: As pessoas são mal informadas, os próprios políticos também não tem um grau de conhecimento na área ambiental, eu falo assim é zero, aí ficam influenciados por pessoas que também não têm um conhecimento, não sabem até do potencial o que um município pode arrecadar hoje com a RESEX, no entorno, que nem o caso de Juruá, os benefícios que pode adquirir . E então, a própria prefeitura eles desperdiçam tudo isto. Poderiam conseguir muitas coisas, mas não conseguem. Hoje nem sequer um deslizador para a Secretaria de Meio Ambiente do Município que não existe.

Já o desmatamento foi um problema que a gente enfrentou, eu fiz bastante denúncia quando eu vim para cá, em 2005. Os meninos do IBAMA. Aí veio uma fiscalização, porque a nossa Amazônia não é propícia para a criação de gado; nossos solos é frágil, e para que se coloque uma cabeça de gado você tem que desmatar vinte hectares. Então não é propícia. E o que aconteceu? Antes estas pessoas fizeram grandes desmatamentos mesmo em 2005. Tinha áreas aí perto de 100 ha, já quase na RESEX. Em tão o que aconteceu? A gente entrou em contato com Manaus, os meninos vieram, fizeram um sobrevôo, de monomotor, viram e chegaram até estas pessoas que estavam fazendo, tanto autores quanto co-autores e fizeram a infração. Pegaram eles e multaram. Eles pararam mais. Não que, pela falta de estrutura que o IBAMA tem, as pessoas estarem presentes, os fiscais do IBAMA, pelo também o tamanho da nossa área, o Amazonas aqui é quase continental e pela quantidade de fiscais do IBAMA, deixa muito a desejar. Inibe naquele momento, mas depois as pessoas voltam até a fazer assim, porque menos de mês em mês tem um fiscal aqui. Fica um pouco a desejar. Não que esteja fazendo direto. Mas dizer que não existe. Existe desmatamento sim e não é pouco.

LL - E a questão dos índios? Há invasões?

- Recentemente, quando eu estava vindo para cá, de férias, teve um problema dos índios quiseram invadir a área da RESEX. Mas não é comum não. 
LL - E hoje, Luis, qual a principal luta da Associação para conseguir para a reserva?

- Ela tem exigir o mais rápido possível do IBAMA, já que está tudo legal, o Plano de Manejo, o plano de uso geral e a presença do IBAMA também. Eu sei que a burocracia que houve com este Instituto aí o Chico Mendes, a gente não sabe como vai ficar, mas seria essencial a presença das meninas aqui, ou a Goretti, ou a outra agora, que eu não lembro o nome. Nem que ela passasse dez dias a cada mês aqui, ou cinco dias, mas seria muito importante. E para ter agilidade no serviço tanto do IBAMA, quanto da associação, nos projetos, ver onde estão os recursos alocados, para conseguir benefícios para a área da comunidade, seria uma Internet, para a gente ter mais agilidade. Porque hoje a nossa dificuldade é ter que mandar por correio um projeto para chegar em Brasília que leva aí quase três meses. Outra coisa importante seria a mão-de-obra: começou por mim, voltei mas tive que sair. Ter uma pessoa aqui, com o mínimo de conhecimentos para ajudar os meninos aqui. Por isto que eu falo, a presença do IBAMA seria muito importante, porque a associação não tem como bancar ninguém, um funcionário para ficar fixo para este conhecimento, para fazer elaboração de projetos, ter uma agilidade maior nestas transações bancárias, na documentação, que a senhora sabe, sempre leva um pouco de burocracia. Então tem que ter uma pessoa com conhecimento para que esse serviço seja o mais agilizado e saia os projetos com maior rapidez. 


\section{ANEXO B}

Histórico ASTRUJ

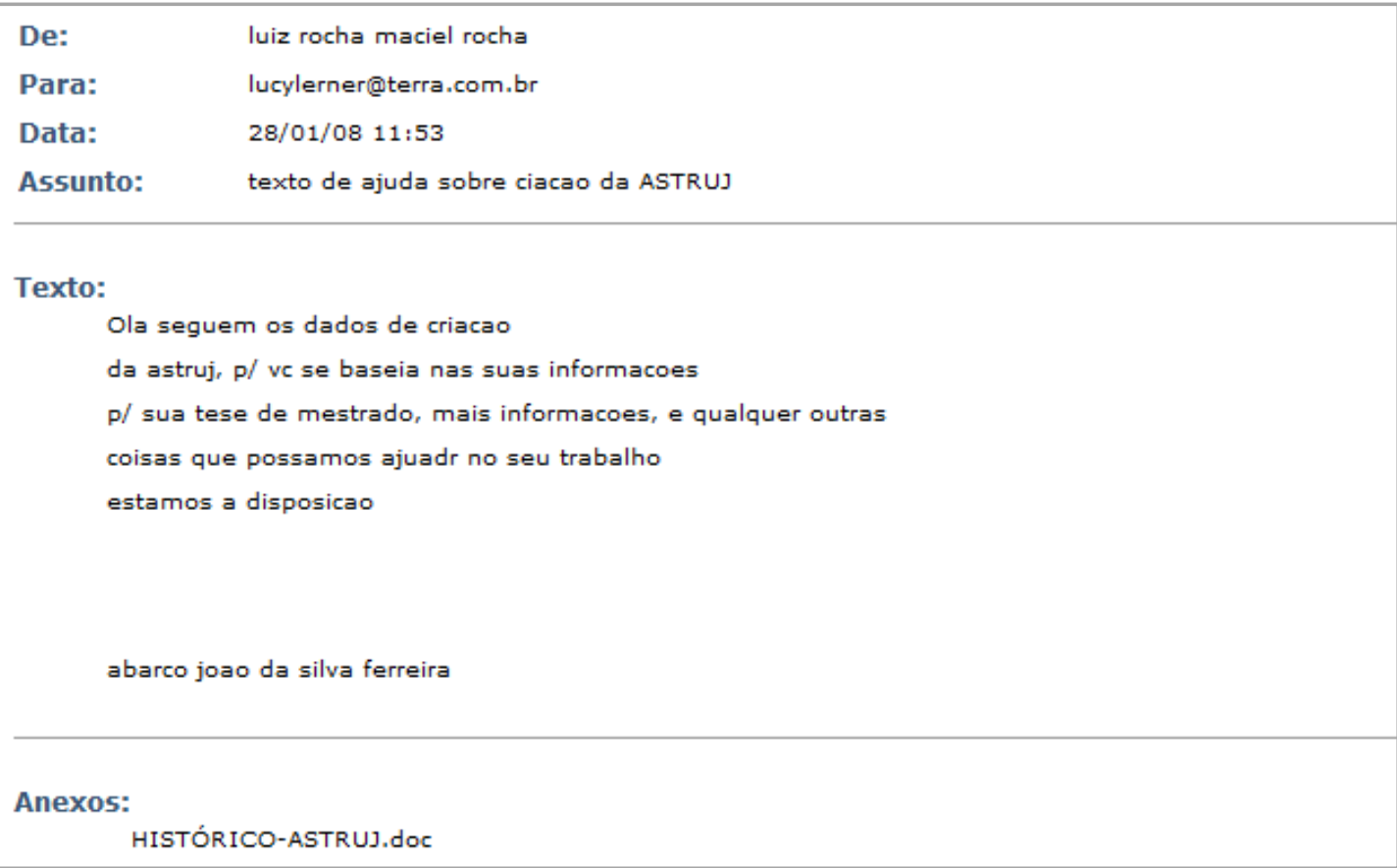




\section{HISTÓRICO DA RESEX DO BAIXO JURUÁ}

\section{1 - INTRODUÇÃO}

Com a preocupação de se implantar uma política de preservação para alguns lagos do Município de Juruá, a PRELAZIA DE TEFÉ em meados dos anos 70 (setenta), iniciou um arduo trabalho em nosso Município, tendo como papel fundamental a presença do Irmão FALCO, o qual insessantemente lutou pela criação do COMITÊ DE PRESERVAÇÃO. Apartir de então, não só a prelazia, como também a participação de todas as comunidades, e as parcerias com o IBAMA, CNPT, GPD, GTA, e MEB, juntos começaram a discurtir a necessidade da formação de agentes ambientais voluntários (AAV), e já em meados dos anos 90 (noventa), começaram a ser ministrados os respectivos cursos em quase toda a jurisdição da prelazia de Tefé, desta forma criava-se uma nova consciência na cabeça da população juruaense de modo a imaginar uma nova pespectiva de vida para as futuras gerações.

\section{2 - MOTIVO DA CRIAÇÃO DA ASSOCIAÇÃO.}

No decorrer dos anos aprimorava-se, alimila-se mais conhecimentos de presevação, e determinados a mudar de vida, visto que as dificuldades de apoio logísticos e de infraestrutura, tornavam as dificuldades (já existente) mais penosa para as comunidades atenderem as demandas que 0 
trabalho voluntário exige, diante de tudo isto as comunidades se organizaram e no ano de 1998 nasceu a Associação dos Trabalhadores Rurais de Juruá - ASTRUJ, com muita luta e muitos problemas, mas também com muitas vitórias e conquistas, nasce com ela possibilidades de uma forma geral, pois agora se tem uma entidade e representatividade.

\section{3 - OBJETIVO DA CRIAÇÃO DA RESERVA:}

O principal objetivo da criação da Reserva Extrativista do Baixo Juruá era assegurar o uso sustentável e a conservação dos recursos naturais renováveis, e proteger os meios de vida e a cultura da população extrativista local, de modo a proporcionar uma melhor qualidade de vida, aos comunitários que dali tiram os seus alimentos diariamente e para que assim ninguém de fora da Reserva venha a dilapidar o seu maior tesouro que é a sua faúna e flora desta região.

\section{4 - ATIVIDADES PRINCIPAIS DE GERAÇÃO DE RENDAS:}

Dentro da Geração de renda familiar dos comunitária da RESEX do Baixo Juruá destacam-se: agricultura familiar, extrativismo( pesca e extraçâo de madeira), artesanatos,etc. Também fazem parte da geração de renda a Aquisições de Projetos pelo: FNMA, e os Acentamentos pelo INCRA. 


\section{5 - EXTENSÃO TERRITORIAL}

A Reserva Extrativista do Baixo Juruá possui aproximadamente 188.000 hectares, sendo que desta área $60,5 \%$ se localiza no Município de Juruá - AM, e 30,5\% se localiza no Município de Uarini -AM, abrangendo 13 Comunidades, que são: Botafogo, Antonina, Vai- Quem-Quer, Morada Nova, Socó, Forte da Graças I e II, São Francisco, Oito Voltas, Lago Grande, Escondido, Cumarú, e Igarapé do Branco.

\section{CONCLUSÃO}

Desde a criação da ASTRUJ, em 1998, foi que houve uma luta intensa por parte da maioria destes comunitários, porém não foi fácil, pois não eram só os comunitários de Juruá que se engajavam nesta luta, nós tínhamos apoio de outros companheiros de outros municípios que estavam lutando com o mesmo objetivo, que culminou, depois de muita luta, na Criação da Resex do Baixo Juruá • AM, fato que foi Decretado em 01 de Agosto de 2001, e que hoje atende 13 (treze) Comunidades e 125 (cento e vinte e cinco) famílias.

Entretanto, tínhamos o objetivo também de chamar a atenção dos nossos governantes para ficarem lado a lado para juntos compartilharmos todos os problemas que passamos quanto ao que são nossos direitos e deveres, e desta forma poder assegurar os deveres de preservção de nosso habitat natural, e os nossos direitos a saúde, educação, infraestrutura, saneamento, direitos sociais e geração de renda para uma melhor qualidade de vida. 


\section{REFERÊNCIAS}

ALLEGRETTI, M.H. Reservas Extrativistas: Parâmetros para uma política de desenvolvimento sustentável na Amazônia. In: ANDERSEN, Anthony (et all). 0 destino da floresta: reservas extrativistas e desenvolvimento sustentável na Amazônia. Rio de Janeiro: Relume- Dumará; Curitiba: Instituto de Estudos Amazônicos e Ambientais, Fundação Konrad Adenauer, 1994.

AZEVEDO, Cleidimar Ribeiro de \& APEL, Marcelo. Co-gestão: Um processo em construção na várzea amazônica. Manaus: Ibama, 2004

BENSUSAN, Nurit et al. Introdução. BENSUSAN, Nurit et al (Orgs.).

Biodiversidade: é para comer, vestir para passar no cabelo? Para mudar o mundo! São Paulo: Petrópolis, 2006.

BENSUSAN, Nurit. Conservação da biodiversidade em áreas protegidas. Rio de Janeiro: FGV, 2006.

BOBBIO, Norberto. Estado, governo, sociedade; por uma teoria geral da política. Trad. Marco Aurélio Nogueira. Rio de Janeiro: Paz e Terra, 1987.

BRASIL. Constituição Federal, Artigo 225. Todos têm direito ao meio ambiente ecologicamente equilibrado, bem de uso comum do povo e essencial à sadia qualidade de vida, impondo-se ao poder público e à coletividade o dever de defendêlo e preservá-lo para as presentes e futuras gerações. Disponível em:

www.planalto.gov.br/ccivil_03/Constituicao/Constituiçao.htm

BRASIL, Lei $\mathrm{n}^{\circ}$ 9.985, de 18 de junho de 2000. Regulamenta o art. 225, § $1^{\circ}$, incisos I, II, III, e VII da Constituição Federal, institui o Sistema Nacional de Unidades de Conservação da Natureza e dá outras providências. Artigos $4^{\circ}, 7^{\circ}, 8^{\circ}$, e $9^{\circ}$.

BRASIL. Decreto $\mathrm{n}^{\circ}$ 4.339, de 22 de agosto de 2002. Institui princípios e diretrizes para a implementação da Política Nacional da Biodiversidade.

BRASIL. Decreto 4.703, de 21 de maio de 2003. Dispõe sobre o Programa Nacional da Diversidade Biológica - PRONABIO e a Comissão Nacional da Biodiversidade, e dá outras providências. Disponível em:

www.planalto.gov.br/ccivil_03/decreto/2003/D4703.htm - acesso em 03 de agosto de 2007. 
BRASIL. Decreto 6.101, de 26 de abril de 2007(a). Aprova a Estrutura Regimental e o Quadro Demonstrativo dos Cargos em Comissão e das Funções Gratificadas do Ministério do Meio Ambiente, e dá outras providências.

BRASIL. Medida Provisória 375, de 15 de junho de 2007(b). Fixa a remuneração dos cargos e funções comissionadas da administração pública federal direta, autárquica e fundacional, e dá outras providências.

BRASIL. Lei $n^{0}$ 11.516, de 28 de agosto de 2007(c). Dispõe sobre a criação do Instituto Chico Mendes de Conservação da Biodiversidade - Instituto Chico Mendes; altera as Leis nos 7.735, de 22 de fevereiro de 1989, 11.284, de 2 de março de 2006, 9.985, de 18 de julho de 2000, 10.410, de 11 de janeiro de 2002, 11.156, de 29 de julho de 2005, 11.357, de 19 de outubro de 2006, e 7.957, de 20 de dezembro de 1989; revoga dispositivos da Lei no 8.028, de 12 de abril de 1990, e da Medida Provisória no 2.216-37, de 31 de agosto de 2001; e dá outras providências. Artigo $1^{\circ}$, inc. I.

BRASIL, Ministério do Meio Ambiente. Primeiro Relatório Nacional par a Conservação sobre Diversidade Biológica. Brasília, 1998.

BRASIL. Ministério do Meio Ambiente. Instrução Normativa ${ }^{\circ}$ 05, de 21 de maio de 2004.

BRASIL. Ministério do Meio Ambiente. Instrução Normativa nº 03, de 26 de maio de 2006.

COMEGNA, Maria Ângela. A Convenção sobre Biodiversidade e as comunidades locais na Bolívia. 2006. 138p. Dissertação (Mestrado em Geografia) - Programa de Pós-Graduação em Geografia Humana da Universidade de São Paulo, São Paulo.

CUNHA, Manuela Carneiro da. Saber Tradicional. Folha de São Paulo, São Paulo, 19/02/2000, Tendências/ Debates, p. A3.

DALLARI, Dalmo de Abreu. O futuro do Estado. São Paulo: Moderna, 1980.

DERANI, Cristiane. Direito Ambiental Econômico. São Paulo: Max Limonad, 1997.

ELLIOTT, Lorraine. The Global Politics of the Environment. Houndmills, Basingstoke, Hampshire: Macmillan Press, 1998.

FISCHER, Carlos Fernando Anicet; CHAGAS, Ana Lucia da Graças Amador; DORNELLES, Lia Drumond Chagas. Pesca de Águas Interiores. Coleção Meio Ambiente. Série Estudos: Pesca, n.2. Brasília: Instituto Brasileiro do Meio Ambiente e dos Recursos Naturais Renováveis, 1992. 
FORMENTI, Ligia. Não haverá refúgios no país. O Estado de São Paulo. São Paulo, 03/02/2007. Vida\&. http://txt.estado.com.br/editorias/2007/02/03/ger1.93.7.20070203.13.1.xml

FREY, Klaus. Políticas Públicas: um debate conceitual e reflexões referentes à prática da análise de políticas públicas no Brasil. In: Planejamento e Políticas Públicas. No 21, Junho de 2000 www.ipea.gov.br/pub/ppp/ppp21/Parte5.pdf. Acesso em 01 de dezembro de 2005.

FUNBIO Fundo Brasileiro para a Biodiversidade. Relatório Anual, 2004. Rio de Janeiro: Funbio, 2005, 76p

GONÇALVES, Carlos Walter Porto. Amazônia, Amazônias. $2^{\text {a }}$ Ed .São Paulo: Contexto, 2005.

WEIGAND JR, Ronaldo \& PAULA, Daniela J. de. Reserva Extrativista: Dando Poder às Comunidades através da Elaboração e Implantação Participativas do Plano de Desenvolvimento. Porto Velho: SEPLAN/SEDAM/PLANAFLORO/PNUD/BRA/ 94/007 1998. 76p.

IBAMA, Processo nº 02005.001201/97a-33.

IBAMA. Estudo Sócio-Econômico Área Proposta para a criação da Reserva Extrativista do Baixo Juruá. Manaus, 1998

IBAMA. Relatório Nacional do Brasil, $2^{\text {a }}$ Versão. In: Congresso Latino Americano de Parques Nacionais e Outras Áreas Protegidas, 1. Brasília, 1997b.

RIBEIRO, Wagner, Costa. A Ordem Ambiental Internacional. São Paulo: Contexto, 2001.

INOUE, Cristina Yumie Aoki. Regime global de biodiversidade: o caso de Mamirauá. Brasília: Universidade de Brasília, 2007.

IPCC. IPCC Fourth Assessment Report - Climate Change 2007. Working Group II:Impacts, Adaptation and Vulnerability. Geneva, World Meteorological Organization and United Nations Environment Programme

IPCC. IPCC Third Assessment Report - Climate Change 2001. Working Group II:Impacts, Adaptation and Vulnerability. Geneva, World Meteorological Organization and United Nations Environment Programme

JACOBI, Pedro. Governança dos Recursos Hídricos no Brasil: realidade, desafios e perspectivas. In: I Seminário Nacional sobre Governança Ambiental no Brasil: Contexto, Realidade Rumos, 2006. Recife: Fundação Joaquim Nabuco, 2006.

JACOBI, Pedro. Movimento Ambientalista no Brasil: Representação Social e Complexidade da Articulação de Práticas Coletivas. In: RIBEIRO, Wagner Costa 
(org.). Patrimônio Ambiental Brasileiro. São Paulo: Editora da Universidade de São Paulo: Imprensa Oficial do Estado de São Paulo, 2003.

KELSEN, Hans. Teoria Geral do Estado. Coimbra: Armênio Amado Editor, 1951.

LE PRESTRE, Philippe. Ecopolítica Internacional. São Paulo: SENAC. São Paulo, 2000 .

LIMA, André et BENSUSAN, Nurit (Orgs.). Quem cala consente? Subsídios para a proteção dos conhecimentos tradicionais. São Paulo: ISA, 2003. 295p.

LITTLE, Paul E. Os desafios da política ambiental no Brasil. In: LITLLE, Paul E. (Org.) . Políticas Ambientais no Brasil: análises, instrumentos e experiências. São Paulo: Petrópolis, Brasília, DF: IEBB, 2003.

MACHADO, Paulo Affonso Leme. Direito Ambiental Brasileiro, 14 ed, revista atualizada e ampliada. São Paulo: Editora Malheiros, 2006.

MACKINNON, John et al. Managing protected areas in the Tropics. Switzerland: UICN, 1986, 295p.

MANTOVANI, Waldir. A Degradação dos Biomas Brasileiros. In: RIBEIRO, Wagner Costa (org.). Patrimônio Ambiental Brasileiro. São Paulo: Editora da Universidade de São Paulo: Imprensa Oficial do Estado de São Paulo, 2003, p. 541.

MEIRELLES, Hely Lopes. Direito Administrativo Brasileiro, 15 ed. São Paulo: Editora Revista dos Tribunais, 1990.

MELLO, Neli Aparecida de. Políticas territoriais na Amazônia. São Paulo: Annablume, 2006.

MILARE, Edis. Afirmação do CONSEMA como Órgão Integrante do Sistema Nacional de Meio Ambiente. In: SEARA FILHO, Germano. CONSEMA: vinte anos de decisões a favor de São Paulo. São Paulo: SMA, 2004.

MMA - MINISTÉRIO DO MEIO AMBIENTE, DOS RECURSOS HÍDRICOS E DA AMAZÔNIA LEGAL. Primeiro Relatório Nacional para a Convenção sobre a Diversidade Biológica no Brasil. Brasília, 1998.

MMA - MINISTÉRIO DO MEIO AMBIENTE, DOS RECURSOS HÍDRICOS E DA AMAZÔNIA LEGAL. Primeiro Relatório Nacional para a Convenção sobre a Diversidade Biológica no Brasil. Brasília, 1998.

MMA - MINISTÉRIO DO MEIO AMBIENTE. Estratégia Nacional de Diversidade Biológica. Contribuição para a Estratégia de Conservação in situ no Brasil GTT 6. Grupo coordenado por Takako M. Tundisi (CAPES). Revisão dos principais artigos da Convenção sobre Diversidade Biológica, realizada por Grupos de Trabalho Temáticos (GTTs). Disponível em: http://www.mma.gov.br/index.php. Acesso em 25 de março de 2006. 
MMA - MINISTÉRIO DO MEIO AMBIENTE. Informe Nacional sobre Áreas Protegidas. Brasília: 2007.

MMA - MINISTÉRIO DO MEIO AMBIENTE. Política Nacional de Biodiversidade - roteiro de consulta para elaboração de uma proposta. Brasília: MMA/SDB, 2000. 48p.

MMA - MINISTÉRIO DO MEIO AMBIENTE. Projeto de Conservação e Utilização Sustentável da Diversidade Biológica Brasileira:Relatório de Atividade 2002-2004. Brasília: 2004a.73p

MMA - MINISTÉRIO DO MEIO AMBIENTE. Relatório de Atividades do Projeto de Conservação e Utilização Sustentável da Diversidade Biológica Brasileira.

Brasília, 2002

MMA - MINISTÉRIO DO MEIO AMBIENTE. Segundo Relatório Nacional para a Convenção sobre Diversidade Biológica. Brasília: 2004b. 347p.

MMA - MINISTÉRIO DO MEIO AMBIENTE. Terceiro Relatório Nacional para a Convenção sobre Diversidade Biológica. Brasília: 2006

MMA- MINISTÉRIO DO MEIO AMBIENTE. Política Nacional de Biodiversidade - roteiro de consulta para elaboração de uma proposta. Brasília: MMA /SDB, 2000. 48p. (Biodiversidade, 1)

NASCIMENTO E SILVA, Geraldo Eulálio. Direito Ambiental Internacional: meio ambiente, desenvolvimento sustentável e os desafios da nova ordem mundial. Rio de Janeiro: Thex, 1995.

NASCIMENTO, Milton Meira. Filosofia Política. In: CHAUÍ, Marilena, et al. Primeira Filosofia: lições introdutórias. São Paulo: Editora Brasiliense, 1987.

NETO, Joaquim Shiraishi. As Reservas Extrativistas de babaçu. In: LITTLE, Paul E. (org.). Políticas Ambientais no Brasil. São Paulo: Petrópolis; Brasília, DF IEEB, 2003.

NEVES, ANA MARIA BASTOS. Conhecimento Atual sobre o Pirarucu, Arapaima gigas. In: Recursos pesqueiros do médio Amazonas: biologia e estatística pesqueira. Brasília: Edições IBAMA, 2000.

O’DONNELL, Guilhermo. Democracia Delegativa? In: Novos Estudos. N.31, São Paulo: CEBRAP, 1991.

PORTO, Ary Eduardo. Aspectos de Dominialidade. In: AQUINO, Marcelo de \& AZEVEDO Pedro Ubiratan Escorel (Orgs). Regularização Imobiliária de áreas protegidas. São Paulo: Centro de Estudos da Procuradoria Geral do Estado, 1999.

POULANTZAS, Nico. O Estado o poder o socialismo (1978).Trad. Rita Lima. Rio de Janeiro: Graal, 1980. 
REZEK, José Francisco. Direito Internacional Público: curso elementar. $8^{\text {a }}$ ed. São Paulo: Saraiva, 2000.

ROSENBAUN, Walter A. The Politics of Environmental Concern. New York: Praeger, 1977.

RYLANDS, Anthony B e PINTO, Luiz Paulo de S. Conservação da Biodiversidade na Amazônia Barsileira: uma análise dos Sistemas de Unidades de Conservação. In: Cadernos para o Desenvolvimento Sustentável, Vol 1. Fundação Brasileira para o Desenvolvimento Sustentável, 1998.

SACHS, Ignacy. Entrevista concedida à Revista Adiante, Dezembro de 2005, p.10/15.

SANTILLI, Juliana. A Lei 9.985/2000, que instituiu o Sistema Nacional de Unidades de Conservação da Natureza (SNUC): uma abordagem socioambiental. Revista de Direito Ambiental, Ano 10, nº 40, outubro-dezembro de 2005. São Paulo: Revista dos Tribunais, 2005.

SANTOS, Boaventura de Sousa; MENESES, Maria Paula G. de; NUNES, João Arriscado. Introdução: Para ampliar o cânone da ciência: a diversidade epistemológica do mundo. In: SANTOS, Boaventura de Sousa (org.). Semear outras soluções: os caminhos da biodiversidade e dos conhecimentos rivais. Rio de Janeiro: Civilização Brasileira, 2005.

SCHMIDT, Caroline Assunta e PASSOS DE FREITAS, Mariana Almeida. Tratados internacionais de direito ambiental. Curitiba: Juruá, 2006.

SHIVA, Vandana. Biopirataria: a pilhagem da natureza e do conhecimento. Petrópolis: Vozes, 2001

SHIVA, Vandana. Monoculturas da mente: perspectivas da biodiversidade e da biotecnologia. São Paulo, Gaia, 2003.

SILVA, Jose Afonso da. Direito Ambiental Constitucional. São Paulo: Editora Malheiros, 2004.

SILVA, Marina, Histórias da floresta, da vida e do mundo, in VIANA, Gilney; SILVA, Marina;e DINIZ, Nilo (orgs.). O Desafio da Sustentabilidade - um debate socioambiental no Brasil, São Paulo: Fundação Perseu Abramo, 2001.

SOARES, Guido Fernando Silva. Direito internacional do meio ambiente: emergência, obrigações e responsabilidades. São Paulo: Atlas, 2001.

UICN, CPNAP, CMMC. Directrices para las categories de Manejo de Areas Protegidas. Gland, 1994, 261p.

UNEP. Global Environment Outlook 3. London: Earthscan Publications, 2002. 
UNEP. Sustaining life on Earth: how the Convention on Biological Diversity promotes nature and human well-being. April, 2000.

WEFFORT, Francisco (org.). Os Clássicos da Política, 2, 11. ed. São Paulo: Ática, 2006.

WOLFF, Simone. A adequação da legislação ambiental à Convenção sobre

Diversidade Biológica. Brasilia: Ministério do Meio Ambiente/Secretaria de Biodiversidade e Florestas, 2000. 88 p

ZANIRATO, Silvia Helena e RIBEIRO, Wagner Costa. Conhecimento tradicional e propriedade intelectual nas organizações multilaterais. Ambient. soc. [online]. 2007, vol. 10, no. 1 [citado 2008-01-30], pp. 39-55. Disponível em:

http://www.scielo.br/scielo.php?script=sci_arttext\&pid=S1414-753X2007000100004 \&lng=pt\&nrm=iso. Acesso em 15 de dezembro de 2007.

Endereços eletrônicos

6 . Conferência das Partes da CDB em Hague 2002: www.cbd.int/doc/meetings/cop/ cop-06/official/cop-06-18- add1-em.pdf -acesso em 16 de dezembro de 2007

CI - Brasil: www.conservation.org.br

Convenção de Viena sobre Direito dos Tratados: www2.mre.gov.br/dai/dtrat.htm Acesso em 06 de fevereiro de 2007.

FUNBIO - Fundo Brasileiro para a Biodiversidade: www.funbio.org.br

GEF - Global Environment Facility: www.gefweb.org

IPCC - Intergovernmental Panel on Climate Change: www.ipcc.ch

MMA - Ministério do Meio Ambiente: www.mma.gov.br

PNUD- Brasil Programa das Nações Unidas para o Desenvolvimento:

www.pnud.org.br

Presidência da República Federativa do Brasil: www.presidencia.gov.br

UNEP - United Nations Environment Programme: www.unep.org

Estatuto da Corte Internacional de Justiça: htt://www.trf4.gov.br/trf4/upload/ arquivos/ji_cortes_internacionais/cij-estat._corte_intern._just.pdf - acesso em 06 de fevereiro de 2007. 